\title{
WestVirginiaUniversity
}

THE RESEARCH REPOSITORY @ WVU

Graduate Theses, Dissertations, and Problem Reports

2005

\section{Nitric oxide conversion in a spark-ignited natural gas engine}

\author{
Matthew M. Swartz \\ West Virginia University
}

Follow this and additional works at: https://researchrepository.wvu.edu/etd

\section{Recommended Citation}

Swartz, Matthew M., "Nitric oxide conversion in a spark-ignited natural gas engine" (2005). Graduate Theses, Dissertations, and Problem Reports. 1581.

https://researchrepository.wvu.edu/etd/1581

This Thesis is protected by copyright and/or related rights. It has been brought to you by the The Research Repository @ WVU with permission from the rights-holder(s). You are free to use this Thesis in any way that is permitted by the copyright and related rights legislation that applies to your use. For other uses you must obtain permission from the rights-holder(s) directly, unless additional rights are indicated by a Creative Commons license in the record and/ or on the work itself. This Thesis has been accepted for inclusion in WVU Graduate Theses, Dissertations, and Problem Reports collection by an authorized administrator of The Research Repository @ WVU. For more information, please contact researchrepository@mail.wvu.edu. 


\title{
Nitric Oxide Conversion in a Spark Ignited Natural Gas Engine
}

\author{
Matthew M. Swartz \\ Thesis submitted to the \\ College of Engineering and Mineral Resources \\ at West Virginia University \\ in partial fulfillment of the requirements \\ for the degree of \\ Master of Science \\ in \\ Mechanical Engineering \\ Nigel Clark, Ph.D., Chair \\ Gregory Thompson, Ph.D. \\ Wade Huebsch, Ph.D. \\ Department of Mechanical and Aerospace Engineering \\ Morgantown, West Virginia \\ 2005
}

Keywords: $\mathrm{NO}_{\mathrm{X}}, \mathrm{NO}$, aftertreatment, natural, gas, CHEMKIN 


\section{ABSTRACT \\ Nitric Oxide Conversion in a Spark Ignited Natural Gas Engine \\ Matthew M. Swartz}

Reducing $\mathrm{NO}_{\mathrm{X}}$ emissions from natural gas engines has become increasingly important from an environmental standpoint. A large percentage of stationary engine applications are natural gas fueled. The cleanest of these large bore engines currently produce on the order of one gram of $\mathrm{NO}_{\mathrm{X}}$ per brake-horsepower hour (g/bhp-hr) of work done. The goal of this work is to reduce these emissions to $0.1 \mathrm{~g} / \mathrm{bhp}-\mathrm{hr}$ levels. Selective $\mathrm{NO}_{\mathrm{X}}$ Recirculation (SNR), a technology which will help achieve these $0.1 \mathrm{~g} / \mathrm{bhp}$-hr levels, is currently being studied at West Virginia University. SNR has been proven in gasoline and diesel engines, with up to $90 \% \mathrm{NO}_{\mathrm{X}}$ conversion rates being achieved, but not much is known about its overall efficiencies when used with natural gas engines. This technique involves adsorbing $\mathrm{NO}_{\mathrm{X}}$ from an exhaust stream, then selectively desorbing the $\mathrm{NO}_{\mathrm{X}}$ into a concentrated $\mathrm{NO}_{\mathrm{X}}$ stream, which is fed back into the engine's intake, thereby converting a percentage of the concentrated $\mathrm{NO}_{\mathrm{X}}$ stream into harmless gases. Understanding the $\mathrm{NO}$ (a component of $\mathrm{NO}_{\mathrm{X}}$ ) conversion process plays a major role in optimizing the SNR technology.

The emphasis of this thesis is on the unique chemical kinetic modeling problem that occurs with high concentrations of $\mathrm{NO}_{\mathrm{X}}$ in the intake air of a spark ignited natural gas engine with SNR. NO conversion experiments were performed on a Cummins natural gas engine, and CHEMKIN, a chemical kinetic solver software package was used to simulate 
this process. A closed homogeneous batch reactor model was used to model the concentration of $\mathrm{NO}_{\mathrm{X}}$ versus time for an initial mixture of $\mathrm{NO}, \mathrm{O}_{2}, \mathrm{~N}_{2}$, and $\mathrm{CH}_{4}$. A zerodimensional model was used to model the $\mathrm{NO}_{\mathrm{X}}$ conversion properties of a natural gas engine. The molar fraction of $\mathrm{NO}_{\mathrm{X}}$ was monitored on small time scales, on the order of the time for complete combustion, and on large time scales, on the order of minutes. Predicting the mole fraction of $\mathrm{NO}_{\mathrm{X}}$ as a function of time using a closed homogenous batch reactor model on small time scales allowed estimates of the percentage of NO converted locally during the combustion process. These percentages were then compared with experimental values, which were acquired from a Cummins 10 liter spark ignited natural gas engine. The model predicted conversion rates, based on percentage mass conversion, varying between $20 \%$ and $26 \%$, and experiments showed conversion rates between $18 \%$ and $23 \%$ for a constant intake NO concentration of 25,000 ppm. Predicting $\mathrm{NO}_{\mathrm{X}}$ concentration on large time scales, steady state, confirmed that the $\mathrm{NO}_{\mathrm{X}}$ conversion phenomenon, over the in-cylinder time period in which combustion temperatures are maintained, is rate limited rather than equilibrium limited. This gives insight into how to maximize these conversion efficiencies for the SNR process. If the process is rate limited rather than equilibrium limited combustion temperature will play a larger role in NO conversion.

Once the experimental setup was modeled, CHEMKIN was then used to predict the effects of EGR and varying air-to-fuel (A/F) ratios on SNR efficiencies. CHEMKIN demonstrated that under ideal conditions, increasing the air to fuel ratio and adding EGR will increase NO conversion efficiency by up to $90 \%$. 


\section{ACKNOWLEDGEMENTS}

I will start by extending my gratitude to Dr. Nigel Clark for giving me the opportunity to work at the National Research Center for Alternative Fuels, Engines and Emissions at West Virginia University. I would also like to thank my soon to be wife Nichole for her unending support in helping me make it through these last few years of college, without her I would be lost. I am also grateful to Ron Fiskum, Tom George, William Cary Smith, and Raj Sekar for their sponsorship and funding through the ARES university program.

I would also like to extend my gratitude to Dr. Gregory Thompson for his knowledge of the laboratory equipment, and Tom Spencer for his knowledge and humor. I thank Chamila, Emre, and Ram for their friendship and skills at the fooseball table, and also for their help with this research. I would also like to thank my brother and best man Craig for his interesting conversation, and my parents for their advice. 


\section{TABLE OF CONTENTS}

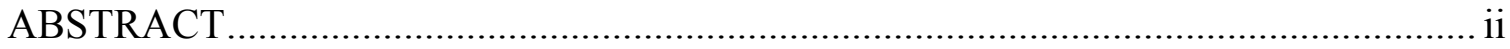

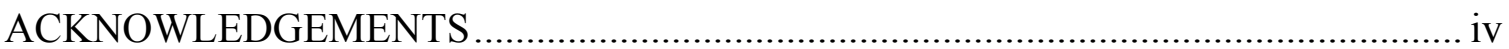

TABLE OF CONTENTS ……………………………………………………………

LIST OF TABLES .................................................................................................... vii

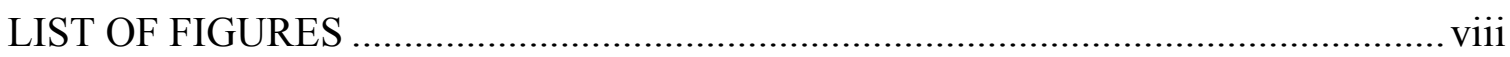

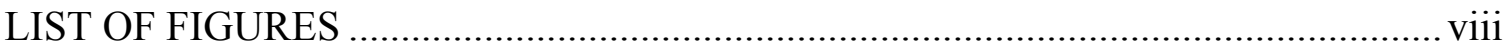

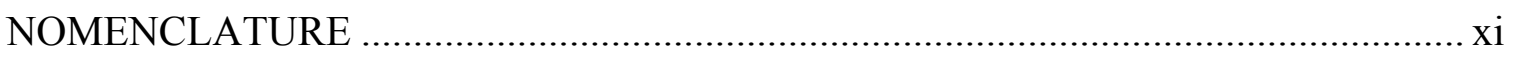

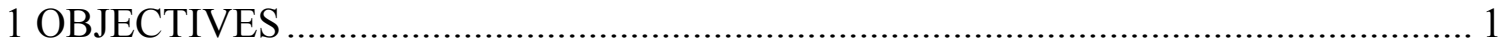

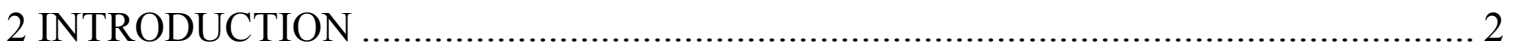

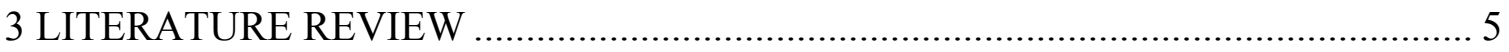

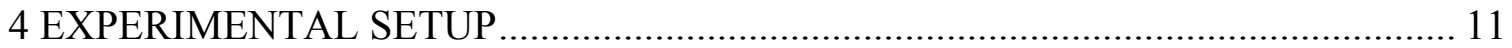

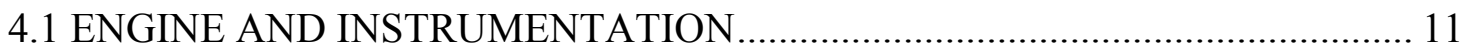

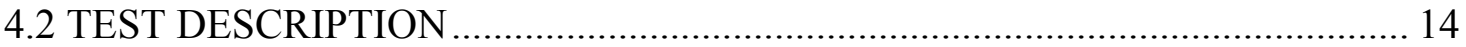

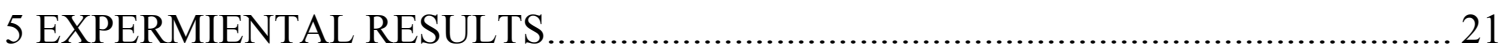

5.1 VARIED CONCENTRATION AND CONSTANT CONCENTRATON

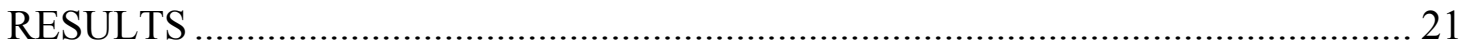

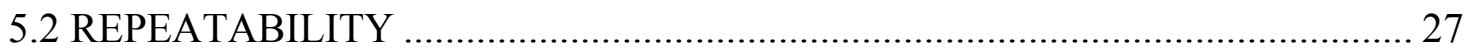

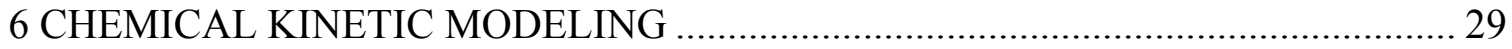

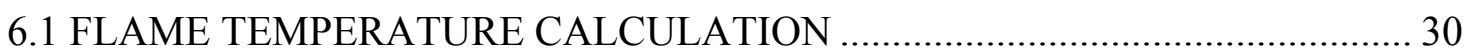

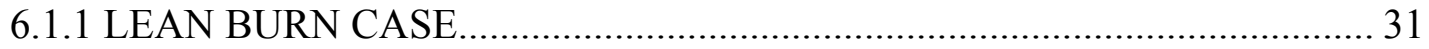

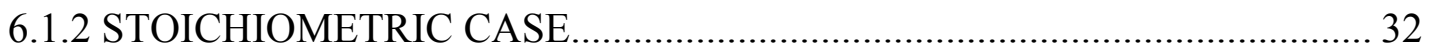

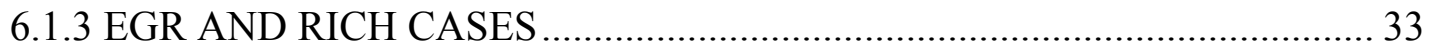




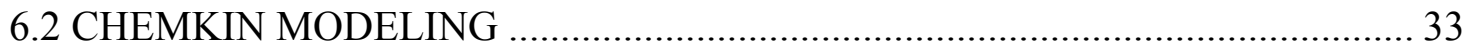

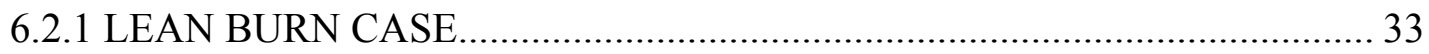

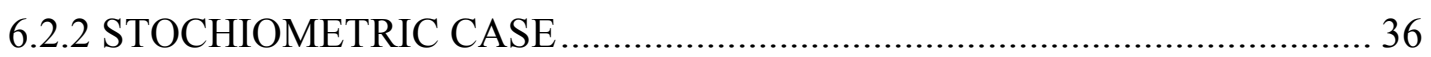

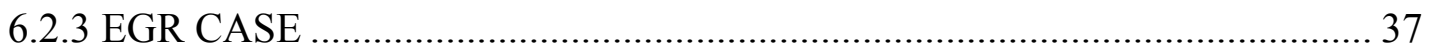

6.2.4 LEAN BURN WITH EGR CASE ............................................................ 37

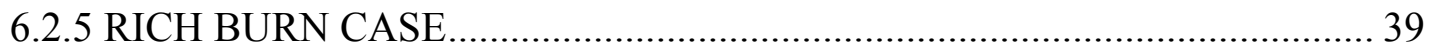

7 CHEMICAL KINETIC MODELING RESULTS …………….................................. 40

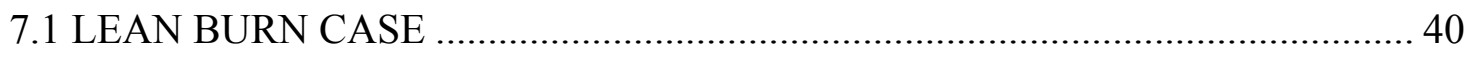

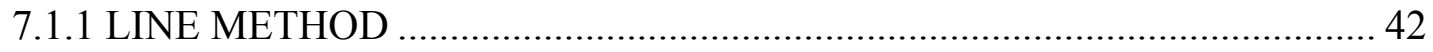

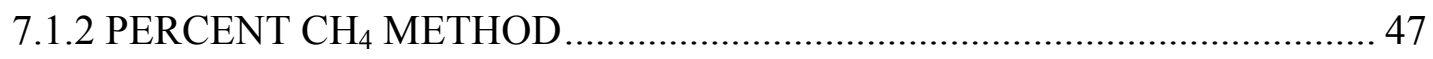

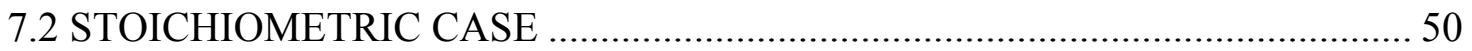

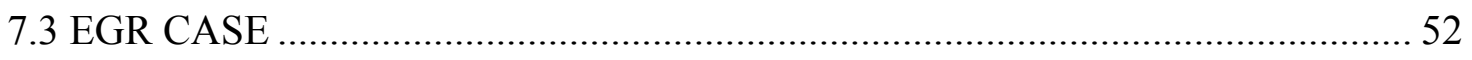

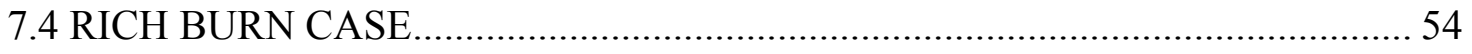

7.5 SUMMARY OF CHEMICAL KINETIC MODELING RESULTS ....................... 56

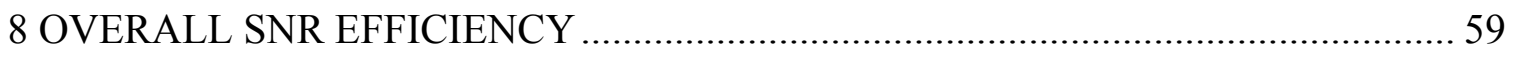

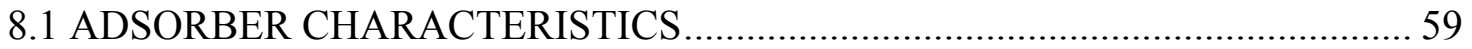

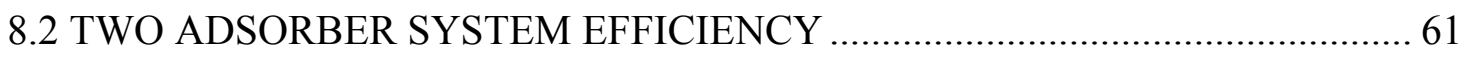

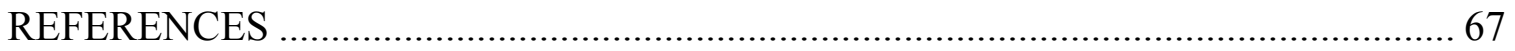

APPENDIX A: GRIMECH VERSION 3.0 CHEMKIN INPUT FILE ............................ 71 


\section{LIST OF TABLES}

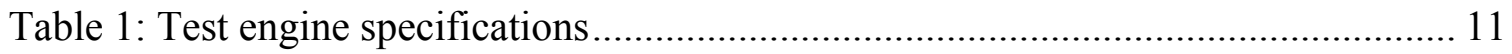

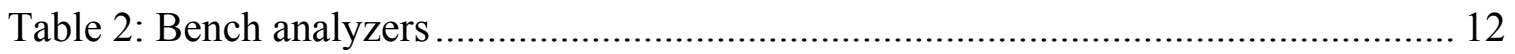

Table 3: Baseline emissions for $\mathrm{HC}, \mathrm{CO}, \mathrm{CO}_{2}$, and $\mathrm{NO}_{\mathrm{X}}$ for varying loads ................... 14

Table 4: Varying injection quantities of $\mathrm{NO}$ at constant engine speed and load............. 20

Table 5: Varying engine load at constant engine speed and injection quantities of NO .. 20

Table 6: Comparison of mass flow controller and gas analyzer NO values for the constant

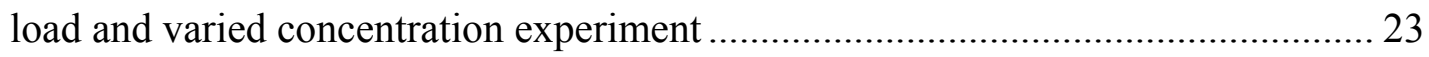

Table 7: Comparison of mass flow controller and gas analyzer NO values for the constant concentration and varied load experiment .................................................... 23

Table 8: Reactant enthalpies (intake composition) ................................................. 31

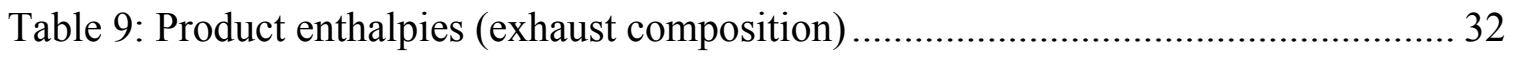

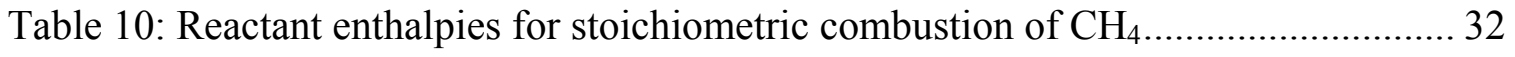

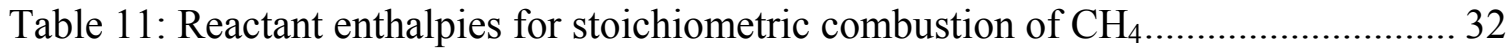

Table 12: Mole fractions of mixtures used in modeling the constant volume process..... 34

Table 13: Temperature and initial pressure with CHEMKIN solver time step and end

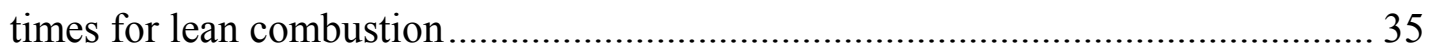

Table 14: Temperature and initial pressure with CHEMKIN solver time step and end times for stoichiometric combustion............................................................ 37

Table 15: EGR and intake air mixture for lean combustion with EGR .......................... 38

Table 16: EGR, intake air, and NO mixture for lean combustion with EGR .................. 39

Table 17: EGR, intake air NO, and fuel mixture for lean combustion with EGR ........... 39

Table 18: Initial mixture of gases for the rich burn case ......................................... 39 


\section{LIST OF FIGURES}

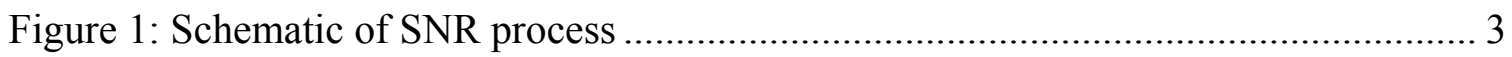

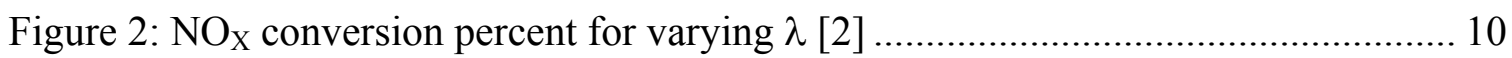

Figure 3: Baseline $\mathrm{NO}_{\mathrm{X}}$ emissions for the Cummins $\mathrm{L} 10 \mathrm{G}$ test engine, reported as $\mathrm{g} / \mathrm{s}$ of

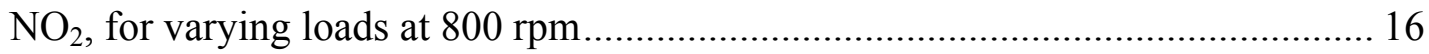

Figure 4: Set and measured load for the $800 \mathrm{rpm}$ set point .......................................... 17

Figure 5: Baseline $\mathrm{HC}$ emissions for the Cummins $\mathrm{L} 10 \mathrm{G}$ test engine for varying loads at $800 \mathrm{rpm}$

Figure 6: Baseline $\mathrm{CO}$ emissions for the natural gas engine for varying loads at $800 \mathrm{rpm}$

Figure 7: Baseline $\mathrm{CO}_{2}$ emissions for the natural gas engine for varying loads at $800 \mathrm{rpm}$

Figure 8: $\mathrm{NO}_{\mathrm{X}}$, reported as $\mathrm{NO}$, for lean combustion, at constant $800 \mathrm{rpm}$ engine speed and $400 \mathrm{ft}-\mathrm{lb}$ load, with varying NO injection quantities into the intake and exhaust

Figure 9: $\mathrm{NO}_{\mathrm{X}}$, reported as $\mathrm{NO}$ lean combustion at constant $800 \mathrm{rpm}$ engine speed and intake air NO injection concentrations of 25,000 ppm.

Figure 10: NO decomposition for varying NO quantities at constant engine speed and load.

Figure 11: NO decomposition vs. engine load for constant concentration and engine speed

Figure 12: Result of varying concentration NO injections on other emissions for the constant $800 \mathrm{rpm}$ and $400 \mathrm{ft}-\mathrm{lb}$ load experiment 26 
Figure 13: Result of NO injections on other emissions for the $800 \mathrm{rpm}$ constant concentration and varied engine load experiment

Figure 14: Two sets of NO injections at $800 \mathrm{rpm}$ and $400 \mathrm{ft}-\mathrm{lb}$ load on different test days 28

Figure 15: Check for solution independence of time step ........................................ 36

Figure 16: Mole fraction of $\mathrm{NO}_{\mathrm{X}}$, reported as $\mathrm{NO}$, for varying initial gas mixtures on a

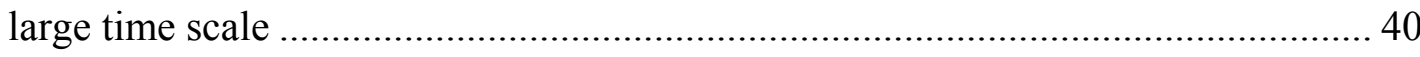

Figure 17: Mole fraction of NO for constant temperature processes............................ 43

Figure 18: Mole fraction of $\mathrm{NO}_{2}$ for constant temperature processes ........................... 44

Figure 19: Mole fraction of $\mathrm{CH}_{4}$ for constant temperature processes .......................... 44

Figure 20: Mole fraction of $\mathrm{NO}_{\mathrm{X}}$, reported as $\mathrm{NO}$, for constant temperature processes on

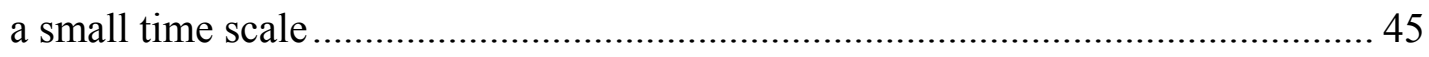

Figure 21: Mole fraction of $\mathrm{NO}_{\mathrm{X}}$, reported as $\mathrm{NO}$ for constant temperature processes on a

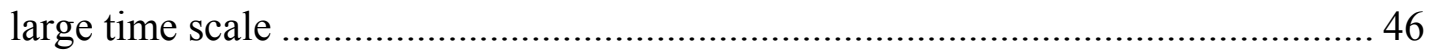

Figure 22: Conversion percentage at various temperatures ..................................... 47

Figure 23: Mass depletion of $\mathrm{CH}_{4}$ for a lean ( $\lambda$ equals 1.4) mixture, with 25,000 ppm NO

Figure 24: Mass conversion of $\mathrm{NO}_{\mathrm{X}}$ for a lean ( $\lambda$ equals 1.4 ) mixture, with $25,000 \mathrm{ppm}$

NO 50

Figure 25: Mass depletion of $\mathrm{CH}_{4}$ for the stoichiometric ( $\lambda$ equals 1) mixture, with 25,000 ppm NO 51

Figure 26: Mass conversion of $\mathrm{NO}_{\mathrm{X}}$ for the stoichiometric ( $\lambda$ equals 1 ) mixture, with 25,000 ppm NO 
Figure 27: Mass depletion of $\mathrm{CH}_{4}$ for a lean ( $\lambda$ equals 1.4 ) mixture, with $20 \%$ EGR and 25,000 ppm NO and

Figure 28: Mass conversion of $\mathrm{NO}_{\mathrm{X}}$ for a lean ( $\lambda$ equals 1.4 ) mixture, with $20 \% \mathrm{EGR}$ and 25,000 ppm NO and 54

Figure 29: Mass depletion of $\mathrm{CH}_{4}$ for the rich ( $\lambda$ equals .9) mixture with 25,000 ppm NO

Figure 30: Mass conversion of $\mathrm{NO}_{\mathrm{X}}$ for a rich ( $\lambda$ equals .9 ) mixture with $25,000 \mathrm{ppm} \mathrm{NO}$ 56

Figure 31: Summary of NO conversion percentages for all cases. 58

Figure 32: Adsorption efficiency as a function of the cooled exhaust gas temperature for varied concentrations of $\mathrm{NO}$ and $\mathrm{NO}_{2}$ averaged over 60 minutes [35] 59

Figure 33: Desorption efficiency as a function of desorb time for $\mathrm{NO}$ and $\mathrm{NO}_{2}$ [35]..... 60

Figure 34: $\mathrm{NO}_{\mathrm{X}}$ emissions for the two adsorber model, with $0.018 \mathrm{~g} / \mathrm{s}$ engine out emissions without aftertreatment and 90\% adsorber efficiency 63 


\begin{tabular}{|c|c|}
\hline $\mathrm{A} / \mathrm{F}$ & Air-Fuel Ratio \\
\hline $\mathrm{Ar}$ & Elemental Argon \\
\hline ARES & Advanced Reciprocating Engine Systems \\
\hline $\mathrm{Ba}\left(\mathrm{NO}_{3}\right)_{2}$ & Barium Nitrate \\
\hline $\mathrm{BaO}$ & Barium Oxide \\
\hline $\mathrm{C}$ & Elemental Carbon \\
\hline $\mathrm{CH}_{4}$ & Methane \\
\hline $\mathrm{CO}$ & Carbon Monoxide \\
\hline $\mathrm{CO}_{2}$ & Carbon Dioxide \\
\hline D.O.E. & Department of Energy \\
\hline EGR & Exhaust Gas Recirculation \\
\hline g/bhp-hr & Grams per Brake Horsepower Hour \\
\hline $\mathrm{H}$ & Elemental Hydrogen \\
\hline $\mathrm{H}_{2} \mathrm{O}$ & Water \\
\hline $\mathrm{HC}$ & Hydrocarbon \\
\hline $\mathrm{HCCI}$ & Homogenous Charge Compression Ignition \\
\hline$\lambda$ & Relative Air-Fuel Ratio \\
\hline LNC & Lean $\mathrm{NO}_{\mathrm{X}}$ Catalyst \\
\hline LNT & Lean $\mathrm{NO}_{\mathrm{X}}$ Trap \\
\hline $\min$ & Minutes \\
\hline $\mathrm{N}$ & Elemental Nitrogen \\
\hline $\mathrm{N}_{2}$ & Nitrogen \\
\hline NGE & Natural Gas Engine \\
\hline $\mathrm{NO}$ & Nitric Oxide \\
\hline $\mathrm{NO}_{2}$ & Nitrogen Dioxide \\
\hline $\mathrm{NO}_{\mathrm{X}}$ & Oxides of Nitrogen \\
\hline NSRC & $\mathrm{NO}_{\mathrm{X}}$ Storage Reduction Catalyst \\
\hline $\mathrm{O}$ & Elemental Oxygen \\
\hline $\mathrm{O}_{2}$ & Oxygen \\
\hline PFR & Plug Flow Reactor \\
\hline PM & Particulate Matter \\
\hline $\mathrm{Pt}$ & Platinum \\
\hline ppm & Parts per Million \\
\hline rpm & Revolutions per Minute \\
\hline RSS & Root Sum of Squares \\
\hline S & Seconds \\
\hline SCR & Selective Catalytic Reduction \\
\hline SI & Spark Ignited \\
\hline SNR & Selective $\mathrm{NO}_{\mathrm{X}}$ Recirculation \\
\hline slpm & Standard Liters per Minute \\
\hline slps & Standard Liters per Second \\
\hline TWC & Three Way Catalyst \\
\hline
\end{tabular}




\section{OBJECTIVES}

- Measure, experimentally, the NO conversion properties of a lean burn, spark ignited natural gas engine operated at low speed steady state conditions, which mimic large bore engine operation and reaction time scales

- Develop a chemical kinetic model that will predict these conversion properties.

- Predict, using the chemical kinetic model, the conversion properties of a natural gas engine for various air-fuel ratios and with exhaust gas recirculation.

- Find the highest theoretical in-cylinder $\mathrm{NO}_{\mathrm{X}}$ conversion that can be achieved.

- Show that $90 \%$ overall $\mathrm{NO}_{\mathrm{X}}$ reductions can be achieved in lean burn natural gas engines with an optimized $\mathrm{NO}_{\mathrm{X}}$ adsorber system. 


\section{INTRODUCTION}

In heavy-duty lean-burn natural gas engines, $\mathrm{NO}_{\mathrm{X}}$ control may be achieved by using wide range oxygen sensor feedback to control the air fuel ratio [1]. Further reductions of $\mathrm{NO}_{\mathrm{X}}$ call for exhaust gas aftertreatment. Large bore natural gas engines, even with careful control, emit an order of magnitude higher $\mathrm{NO}_{\mathrm{X}}$ than the $0.1 \mathrm{~g} / \mathrm{bhp}-\mathrm{hr} \mathrm{NO}_{\mathrm{X}}$ target set by the Department of Energy funded project ARES (Advanced Reciprocating Engine Systems). Conventional $\mathrm{NO}_{\mathrm{X}}$ reduction catalysts cannot be used effectively because the lean-burn exhaust contains excess oxygen, which leads to unfavorable reaction conditions.

SNR involves cooled exhaust gas $\mathrm{NO}_{\mathrm{X}}$ removal by $\mathrm{NO}_{\mathrm{X}}$ adsorption, periodic heating and desorption of $\mathrm{NO}_{\mathrm{X}}$ from the adsorber, and subsequent selective external recirculation and conversion of $\mathrm{NO}_{\mathrm{X}}$ in the cylinder. The exhaust gas must first be cooled to increase the adsororption efficiency of the $\mathrm{NO}_{\mathrm{X}}$ adsorber, and the adsorber heating allows $\mathrm{NO}_{\mathrm{X}}$ to be released from the adsorbent material. The advantages of SNR are that it has no byproducts and does not require a catalyst to reduce $\mathrm{NO}_{\mathrm{X}}$. The $\mathrm{NO}_{\mathrm{X}}$ adsorbers used in the SNR process are also not as susceptible to sulfur poisoning as other competing technologies, which will be discussed in detail in the literature review. A schematic of the SNR process is shown below in Figure 1. The solid black pathways represent the high concentration $\mathrm{NO}_{\mathrm{X}}$ stream that feeds back into the engine, and the exhaust switch is used to divert exhaust flow during the desorption process. This is a basic schematic; other variations include use of a second adsorber, which adsorbs the exhaust diverted during 
desorption of the first adsorber, and the addition of exhaust gas recirculation (EGR). An analysis of the overall efficiency will show that with a two adsorber system overall conversion efficiencies of up to $90 \%$ can be achieved.

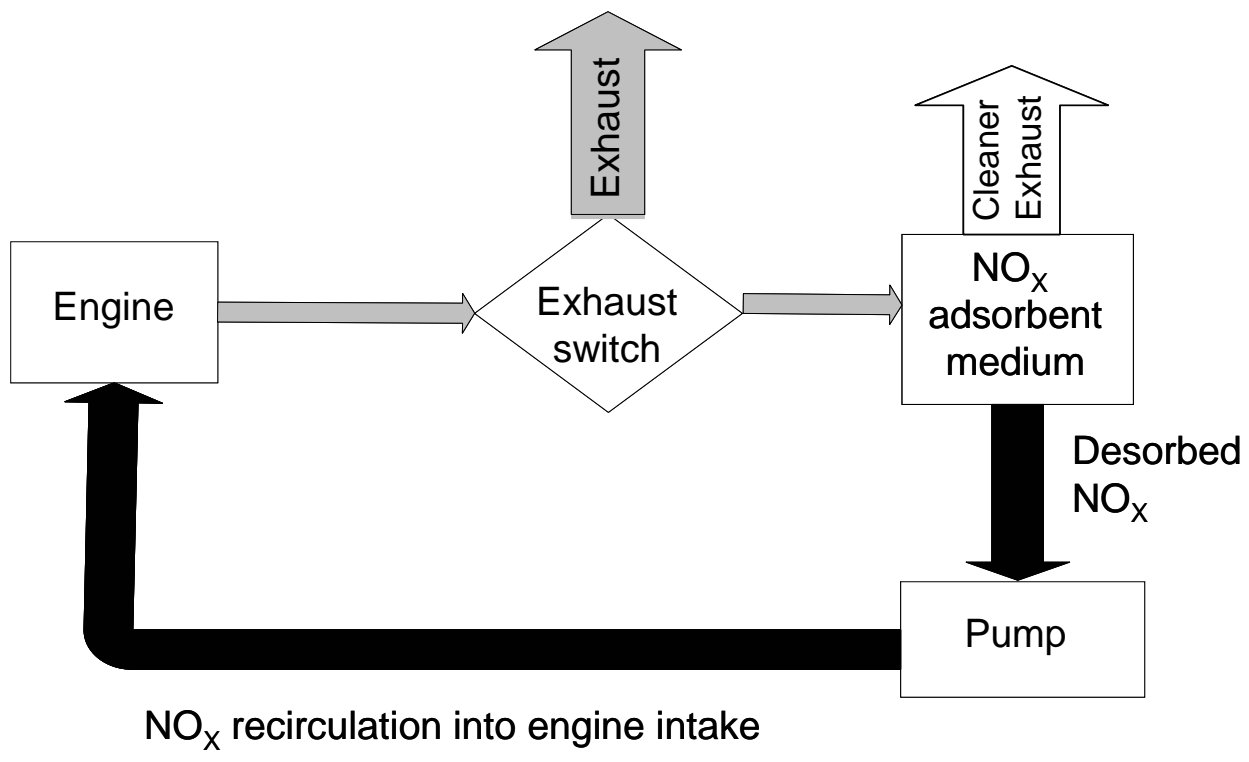

Figure 1: Schematic of SNR process

The SNR technology is in support of the U.S. Department of Energy's goal of reducing $\mathrm{NO}_{\mathrm{X}}$ production rates to $0.1 \mathrm{~g} / \mathrm{bhp}$-hr levels, enabling future use of environmentally acceptable large bore reciprocating natural gas engines. In 1998, Krutzsch et al. [2, 3], found trends similar to those presented in this paper for $\mathrm{NO}_{\mathrm{X}}$ conversion in gasoline and naturally aspirated and turbocharged diesel engines. These researchers achieved $\mathrm{NO}_{\mathrm{X}}$ conversion rates exceeding $50 \%$ in a turbocharged diesel engine operating with direct fuel injection, and conversion rates of up to $90 \%$ in a spark ignited gasoline engine. However, little is known of the potential to convert $\mathrm{NO}_{\mathrm{X}}$ in lean burn natural gas engines. 
Chemical kinetic modeling was executed using the CHEMKIN software package from Reaction Design [4]. This software has been used to model spark ignited natural gas engine combustion characteristics [5], and HCCI combustion and emissions [6, 7]. The CHEMKIN version 4.0 software package makes use of the well tested GRImech version 3.0 reaction mechanism developed by the Gas Research Institute [8]. CHEMKIN uses fundamental heat transfer relationships, reaction rates in the form of a reaction mechanism input file, which includes rates dependent on species, partial pressures, and various coefficients, and temperature dependent thermodynamic transport properties. With this information CHEMKIN solves the equation of state and the energy equation for given initial and boundary conditions supplied by the user. The equations are then solved for time steps specified by the user. The GRImech reaction mechanism and thermodynamic property CHEMKIN input files includes gas phase chemistry, transport, and thermodynamic data, which are used as input files for the CHEMKIN software. The GRImech reaction mechanism files include five elements $\mathrm{C}, \mathrm{H}, \mathrm{O}, \mathrm{N}$, and $\mathrm{Ar}, 53$ chemical species, and 325 reactions [4]. The GRImech reaction mechanism was suitable for this simulation because it captures essential details of methane combustion and $\mathrm{NO}_{\mathrm{X}}$ formation. A list of the species and reaction mechanism are shown in Appendix A. 


\section{LITERATURE REVIEW}

The three-way-catalyst (TWC) has long been used for $\mathrm{NO}_{\mathrm{X}}$ reduction in gasoline engines, which operate under stoichiometric or slightly rich conditions. But the TWC is not an effective tool for reducing $\mathrm{NO}_{\mathrm{X}}$ emissions from lean burn engines, such as the spark ignited natural gas engine being discussed in this thesis. This is due to excess oxygen and lowered $\mathrm{HC}$ and $\mathrm{CO}$ emissions in the exhaust of lean burn engines [9]. Because of this problem, other means of reducing $\mathrm{NO}_{\mathrm{X}}$ emissions need to be developed. An overview and comparison of the various lean burn spark ignition natural gas engine emission reduction technologies was performed by Manivannan et al. [10].

Exhaust gas recirculation, which is a widely used technology in spark ignited natural gas engines, can be used to reduce $\mathrm{NO}_{\mathrm{X}}$ emissions by reducing the flame temperature, and oxygen partial pressure that encourages $\mathrm{NO}_{\mathrm{X}}$ formation [11 - 14]. Some studies have also shown that natural gas engines operating under stoichiometric conditions with the use of a TWC, EGR, and turbo-charging exhibit lower $\mathrm{NO}_{\mathrm{X}}$ emissions, and fuel economy that rivals state-of-the-art lean operating engines $[15,16]$. Similar strategies involving short time period stoichiometric operation are being developed for lean $\mathrm{NO}_{\mathrm{X}}$ trap (LNT) and $\mathrm{NO}_{\mathrm{X}}$ adsorber technologies in diesel and natural gas engines $[17,18]$.

Aftertreatment technologies competing with SNR in an attempt to reach the $0.1 \mathrm{~g} / \mathrm{bhp}-\mathrm{hr}$ goal include Lean $\mathrm{NO}_{\mathrm{X}}$ Catalysts (LNC), $\mathrm{NO}_{\mathrm{X}}$ adsorbers, and Selective Catalytic Reduction (SCR). These technologies are currently being tested and used on lean burn 
natural gas and diesel fueled engines. LNC's selectively promote the reduction of $\mathrm{NO}_{\mathrm{X}}$ by use of hydrocarbons. In the selective catalytic reduction of $\mathrm{NO}_{\mathrm{X}}$, catalysts are used to promote $\mathrm{HC}$ reactions with $\mathrm{NO}_{\mathrm{X}}$ rather than $\mathrm{O}_{2}$, to form $\mathrm{N}_{2}, \mathrm{CO}_{2}$, and water [19].

$$
\mathrm{HC}+\mathrm{NO}_{\mathrm{X}} \rightarrow \mathrm{N}_{2}+\mathrm{CO}_{2}+\mathrm{H}_{2} \mathrm{O} \quad \text { Equation } 1
$$

In lean exhaust gas $\mathrm{HC}$ must be added either by injecting fuel directly into the exhaust gas stream, or by opening the intake valve late thereby letting some unburned fuel pass through the exhaust valve. Even with this $\mathrm{HC}$ enrichment the conversion efficiencies remain in the $30-50 \%$ range with realistic $\mathrm{HC} / \mathrm{NO}_{\mathrm{X}}$ ratios [19]. LNC's also only operate effectively in a small temperature range, which does not always correspond to exhaust temperature, and resistance to catalyst poisons needs to be improved.

$\mathrm{NO}_{\mathrm{X}}$ adsorbers, sometimes referred to as LNT's, $\mathrm{NO}_{\mathrm{X}}$ storage/reduction catalysts (NSRC), or $\mathrm{NO}_{\mathrm{X}}$ adsorber catalysts (NAC), reduce $\mathrm{NO}_{\mathrm{X}}$ by reacting $\mathrm{NO}$ and $\mathrm{O}_{2}$ on a catalyst surface (e.g. platinum) to form $\mathrm{NO}_{2}$ which may still be susceptible to catalyst poisoning. The $\mathrm{NO}_{2}$ is then stored on a storage material, for example barium oxide, as an inorganic nitrate [20].

$$
\begin{aligned}
& \mathrm{NO}+1 / 2 \mathrm{O}_{2} \rightarrow \mathrm{NO}_{2} \\
& \text { Equation } 2 \\
& \mathrm{BaO}+\mathrm{NO}_{2}+1 / 2 \mathrm{O}_{2} \rightarrow \mathrm{Ba}\left(\mathrm{NO}_{3}\right)_{2} \\
& \text { Equation } 3
\end{aligned}
$$


The $\mathrm{NO}_{\mathrm{X}}$ adsorber technology is similar to $\mathrm{LNC}$, because it stores $\mathrm{NO}_{\mathrm{X}}$ on a catalyst surface. However, the LNC must continuously supply $\mathrm{HC}$ to convert $\mathrm{NO}_{\mathrm{X}}$. The $\mathrm{NO}_{\mathrm{X}}$ adsorber adsorbs $\mathrm{NO}_{\mathrm{X}}$ onto a storage material during lean operation, and then converts the $\mathrm{NO}_{\mathrm{X}}$ by passing a rich exhaust stream or $\mathrm{HC}$ enriched exhaust through the adsorber for a short period of time. The conversion mechanisms also differ for these two technologies. The LNC attempts to selectively convert the $\mathrm{NO}_{\mathrm{X}}$ with $\mathrm{HC}$, whereas the $\mathrm{NO}_{\mathrm{X}}$ adsorber uses other species as well as $\mathrm{HC}$ to react with the stored $\mathrm{NO}_{\mathrm{X}}$. Attempts have been made to model the different reaction paths to better understand the $\mathrm{NO}_{\mathrm{X}}$ adsorber chemistry [21].

SCR is similar to LNC technology. However, SCR uses nitrogen compounds such as urea or ammonia as a reductant to convert $\mathrm{NO}_{\mathrm{X}}$ being held on the catalyst surface. With SCR, precise control of reductant injection is required along with continuous feedback from a $\mathrm{NO}_{\mathrm{X}}$ sensor, or a reasonable $\mathrm{NO}_{\mathrm{X}}$ engine model. Using ammonia as a reductant can cause undesirable ammonia emissions, known as ammonia slip, if too much is injected [22]. Urea, normally injected into the exhaust stream in an aqueous solution, presents less of a toxicity issue, but ammonia can still be formed from the hydrolysis of urea. Urea or ammonia must also be continuously supplied, and there are cost issues as well as maintenance issues involved with this [23].

Using methane combustion as a $\mathrm{NO}_{\mathrm{X}}$ reduction technique was initially suggested for regenerable flue gas clean up processes. In large coal fired power plants $\mathrm{NO}_{\mathrm{X}}$ emissions can be reduced by injecting natural gas and $\mathrm{O}_{2}$ into the hot flue gas that comes from coal 
combustion. This process is very similar to the SNR process discussed in this thesis in that the main purpose of this gas reburning is to reduce $\mathrm{NO}_{\mathrm{X}}$ emissions in the flue gas. In 1987 Yeh et al. [24] modeled the $\mathrm{NO}_{\mathrm{X}}$ conversion process using an early version of CHEMKIN, which at the time was being developed by Sandia National Laboratories. The equilibrium-based CHEMKIN solver was used to calculate the thermodynamic feasibility of the gas reburning technology. Equilibrium calculations were performed for various flame temperatures, and varying NO injection quantities. The results showed that natural gas reburning in flue gas could be implemented to reduce over $90 \%$ of the $\mathrm{NO}_{\mathrm{X}}$ emissions [24]. In 1998 the U.S. D.O.E. released a final report on retrofit gas reburning technology in coal fired boilers for flue gas $\mathrm{NO}_{\mathrm{X}}$ reduction [25]. These researchers achieved a cost effective solution with over $60 \% \mathrm{NO}_{\mathrm{X}}$ reduction in various types of coal fired boilers. A chemical kinetic solver was also used in these simulations. The solver used 60 chemical species and 209 reaction mechanisms that define coal devolitilization and combustion. In this case a boiler heat transfer model was used for temperature profiles when modeling $\mathrm{NO}_{\mathrm{X}}$ conversion and equilibrium values were not investigated. A Plug Flow Reactor (PFR) was used to model the flow of gases with varying temperature profiles.

The SNR process, developed in 1998 by Krutzsch et al. [2, 3] for diesel and gasoline engines, found similar trends for $\mathrm{NO}_{\mathrm{X}}$ conversion. In 2005, Vellaisamy et al. [26, 27], confirmed these conversion properties in a 1992 DDC series 60 diesel engine, with detailed effects of the SNR process on PM and other regulated emissions. These researchers achieved $\mathrm{NO}_{\mathrm{X}}$ conversion rates exceeding $50 \%$ in turbocharged diesel engines operated with direct fuel injection. They used similar techniques for finding the 
$\mathrm{NO}_{\mathrm{X}}$ conversion efficiencies, and also performed constant concentration $\mathrm{NO}_{\mathrm{X}}$ conversion studies as will be described in detail in the following sections. A form of the following equation was also taken from [2], which describes the $\mathrm{NO}_{\mathrm{X}}$ conversion efficiency as the flux of $\mathrm{NO}_{\mathrm{X}}$ in the exhaust.

$$
\eta_{N O X}=1-\frac{\left(N O_{X 1}-N O_{X 2}\right)}{N O_{\text {Xfeed }}}
$$

Here $\mathrm{NO}_{\mathrm{X} 1}$ and $\mathrm{NO}_{\mathrm{X} 2}$ represent the $\mathrm{NO}_{\mathrm{X}}$ concentration with and without $\mathrm{NO}$ injection respectively, and $\mathrm{NO}_{\text {Xfeed }}$ is the quantity of $\mathrm{NO}$ injected. Krutzsch et al. [2] found that increased engine load enhanced the conversion efficiency, and also found that the influence of engine speed was small.

Figure 2, taken from Krutzsch et al. [2], represents $\mathrm{NO}_{\mathrm{X}}$ conversion for varying relative air-fuel ratio $(\lambda)$ in a spark ignited (SI) gasoline engine. It was found that running the SI gasoline engine under lean conditions, with a relative air-fuel ratio of 1.45 , the $\mathrm{NO}_{\mathrm{X}}$ conversion efficiency dropped to $20 \%$. This drop in conversion efficiency as the air fuel mixture became leaner in an SI gasoline engine was also predicted for the Cummins L10 natural gas engine used for this research using the CHEMKIN software package. 


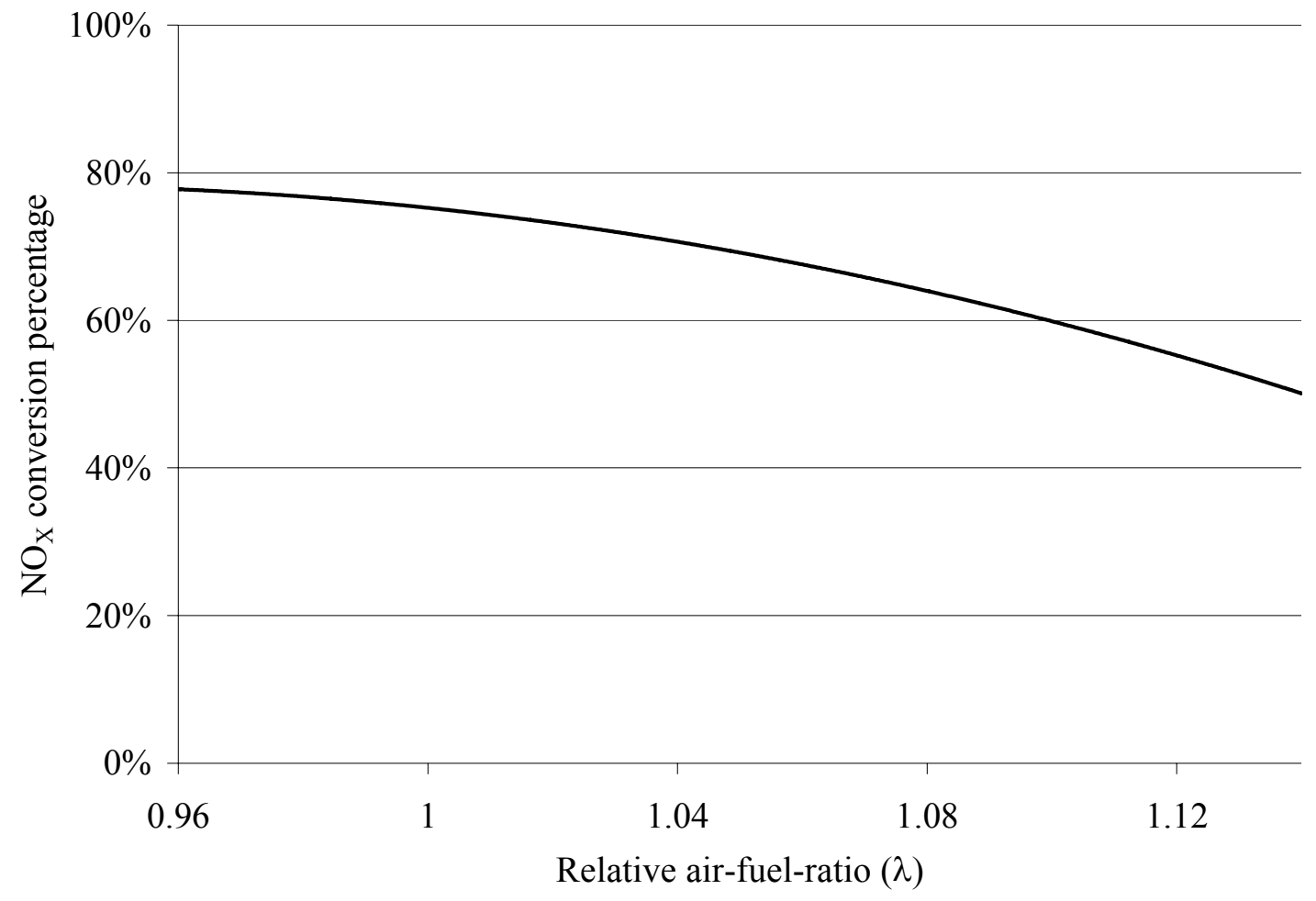

Figure 2: $\mathrm{NO}_{\mathrm{X}}$ conversion percent for varying $\lambda[2]$ 


\section{EXPERIMENTAL SETUP}

The testing procedures and data reduction techniques presented in this thesis are similar to those used by Tissera et al. [28]. NO was injected in varying quantities to represent the concentrated $\mathrm{NO}_{\mathrm{X}}$ stream that would come from the exhaust gas $\mathrm{NO}_{\mathrm{X}}$ adsorber. CHEMKIN was then used to model the chemical kinetics of the $\mathrm{NO}_{\mathrm{X}}$ conversion process. The goal of this modeling was to be able to match experiment and theory. If a correspondence between experiment and theory were found, then CHEMKIN could be used to model other variations of this process, including the addition of EGR and other engine operating conditions, without the expensive cost of experimentation, as with any computational model.

\subsection{ENGINE AND INSTRUMENTATION}

The specifications for the Cummins spark ignited natural gas engine used in this study are listed in Table 1.

Table 1: Test engine specifications

\begin{tabular}{|c|c|}
\hline Engine serial \# & 34683888 \\
\hline Displacement & 10 liters \\
\hline Number of cylinders & 6 (in-line) \\
\hline Firing order & $1-5-3-6-2-4$ \\
\hline Bore & $125 \mathrm{~mm}(4.921 \mathrm{in})$ \\
\hline Stroke & $136 \mathrm{~mm}(5.354 \mathrm{in})$ \\
\hline Compression ratio & $10.5: 1$ \\
\hline Rated power & $240 \mathrm{hp}$ \\
\hline Rated speed & $2100 \mathrm{rpm}$ \\
\hline
\end{tabular}


A $300 \mathrm{hp} \mathrm{Mustang} \mathrm{eddy} \mathrm{current} \mathrm{dynamometer,} \mathrm{controlled} \mathrm{by} \mathrm{a} \mathrm{DYN-LOC} \mathrm{IV} \mathrm{Digital}$ Dynamometer Controller, was used to absorb power output from the engine. The engineout emissions were characterized by directing the exhaust gas to a full-scale dilution tunnel, and employing research grade analyzers to quantify concentrations of the species. All gas measurements taken during this testing followed the procedures outlined for a constant volume sampling system (CVS) in CFR Title 40 part 86 [30]. The dilution tunnel measured 18 inches in diameter, 20 feet in length and was constructed of stainless steel. The dilution tunnel mixing orifice diameter of 10 inches was located 3 feet from the entrance to the tunnel for a uniform mixing of gases. Sample probes for the gas analyzers were located 15 feet, or 10 diameters, from the entrance of the tunnel. The flow in the dilution tunnel was set to $3000 \mathrm{scfm}$.

The gas analyzer bench was capable of quantifying $\mathrm{HC}, \mathrm{CO}, \mathrm{CO}_{2}$ and $\mathrm{NO}_{\mathrm{X}}$. The individual gas detection methods and manufacturers of each gas analyzer are shown in Table 2.

Table 2: Bench analyzers

\begin{tabular}{|c|c|c||}
\hline $\begin{array}{c}\text { Analyzer } \\
\text { Hydrocarbon } \\
\text { analyzer }\end{array}$ & Detection method & Manufacturer \\
\hline $\begin{array}{c}\mathrm{NO}_{\mathrm{X}} \\
\text { analyzers }\end{array}$ & Chemiluminescent & $\begin{array}{c}\text { Rosemont } \\
\text { Analytical }\end{array}$ \\
\hline $\mathrm{CO}$ analyzer & $\begin{array}{c}\text { Non-dispersive } \\
\text { infrared }\end{array}$ & $\begin{array}{c}\text { Horiba } \\
\text { Instruments }\end{array}$ \\
\hline $\mathrm{CO}_{2}$ analyzer & $\begin{array}{c}\text { Non-dispersive } \\
\text { infrared }\end{array}$ & $\begin{array}{c}\text { Horiba } \\
\text { Instruments }\end{array}$ \\
\hline
\end{tabular}


The gas analyzers were calibrated with $\pm 1.0 \%$ accuracy research grade calibration gases. The Rosemount Analytical Chemiluminescent Model $955 \mathrm{NO} / \mathrm{NO}_{\mathrm{X}}$ analyzer used had an accuracy of $\pm 0.5 \%$ of full scale. Since the $\mathrm{NO}_{\mathrm{X}}$ injections were mostly over $50 \%$ of full scale measurement this yielded an overall $\mathrm{NO}_{\mathrm{X}}$ measurement accuracy of $\pm 2.0 \%$. The tunnel flow was calculated using the following relationship:

$$
V_{\text {mix }}=\frac{K \cdot P}{\sqrt{T}}
$$

where $\mathrm{V}_{\text {mix }}$ is the dilution tunnel flow, $\mathrm{K}$ is the venturi coefficient found during calibration, $\mathrm{P}$ is the pressure at the venturi throat, and $\mathrm{T}$ is the absolute venturi throat temperature. Using the root sum of squares (RSS) method of calculating experimental error:

$$
\Delta V_{\text {mix }}=\sqrt{\left(\frac{\partial V_{\text {mix }}}{\partial K} \Delta K\right)^{2}+\left(\frac{\partial V_{\text {mix }}}{\partial P} \Delta P\right)^{2}+\left(\frac{\partial V_{\text {mix }}}{\partial T} \Delta T\right)^{2}} \quad \text { Equation } 6
$$

yielded an uncertainty of $\pm 0.5 \%$ for the tunnel flow when accounting for pressure and temperature measurement device inaccuracies. Using the RSS method of final time yielded an inaccuracy of $\pm 2.5 \%$ for the $\mathrm{NO}_{\mathrm{X}}$ measurements. Due to the nature of this study, steady state comparative study between $\mathrm{NO}_{\mathrm{X}}$ readings operated under the same conditions for each data set, dynamometer and engine setting inaccuracies were not included in this analysis, and since $\mathrm{NO}_{\mathrm{X}}$ is the major relevant species involved in this work, only the uncertainty analysis for $\mathrm{NO}_{\mathrm{X}}$ is shown here. For a detailed uncertainty analysis of the WVU emissions testing laboratory's measurement systems refer to [29]. 


\subsection{TEST DESCRIPTION}

Baseline emissions were taken for $\mathrm{HC}, \mathrm{NO}_{\mathrm{X}}, \mathrm{CO}$ and $\mathrm{CO}_{2}$, at operating conditions shown in Table 3. These emissions data were taken one day prior to the NO injection tests that were performed. These operating conditions were chosen to mimic reaction time scales associated with low speed large stationary engine operation. The sampling rate for the gas analyzers was set to $1 \mathrm{~Hz}$, and the engine operating conditions were set and then allowed to stabilize for $60 \mathrm{~s}$ periods. The emissions were then averaged over $50 \mathrm{~s}$ modes for each operating condition. The $\mathrm{NO}_{\mathrm{X} 1}$ and $\mathrm{NO}_{\mathrm{X} 2}$ data were taken from two separate $\mathrm{NO}_{\mathrm{X}}$ analyzers at the same time to verify the accuracy of the $\mathrm{NO}_{\mathrm{X}}$ readings. Standard deviation of $\lambda$ was less than 0.015 for each engine operating condition. Having small variations in the relative air-fuel ratio $(\lambda)$ were considered important, because $\lambda$ plays a major role in $\mathrm{NO}_{\mathrm{X}}$ production and conversion.

Table 3: Baseline emissions for $\mathrm{HC}, \mathrm{CO}, \mathrm{CO}_{2}$, and $\mathrm{NO}_{\mathrm{X}}$ for varying loads

\begin{tabular}{|c|c|c|c|c|c|}
\hline & $\begin{array}{l}100 \mathrm{ft}-\mathrm{lbs} \\
\text { (a) } 800 \mathrm{rpm}\end{array}$ & $\begin{array}{l}175 \mathrm{ft}-\mathrm{lbs} \\
\text { @ } 800 \mathrm{rpm}\end{array}$ & $\begin{array}{l}250 \mathrm{ft}-\mathrm{lbs} \\
\text { @ } 800 \mathrm{rpm}\end{array}$ & $\begin{array}{l}325 \mathrm{ft}-\mathrm{lbs} \\
\text { @ } 800 \mathrm{rpm}\end{array}$ & $\begin{array}{l}400 \mathrm{ft}-\mathrm{lbs} \\
\text { (a) } 800 \mathrm{rpm}\end{array}$ \\
\hline HC (g/bhp-hr) & 3.60 & 3.43 & 2.92 & 2.83 & 3.17 \\
\hline CO (g/bhp-hr) & 2.59 & 1.79 & 1.52 & 1.43 & 1.38 \\
\hline $\mathrm{CO}_{2}$ (g/bhp-hr) & 670 & 573 & 498 & 440 & 413 \\
\hline $\mathrm{NO}_{\mathrm{x}}(\mathrm{g} / \mathrm{bhp}-\mathrm{hr})$ & 1.82 & 0.68 & 0.61 & 0.84 & 1.09 \\
\hline $\mathrm{NO}_{\mathrm{x} 2}(\mathrm{~g} / \mathrm{bhp}-\mathrm{hr})$ & 1.75 & 0.64 & 0.59 & 0.80 & 1.07 \\
\hline $\mathrm{HC}(\mathrm{g} / \mathrm{s})$ & 0.0158 & 0.0250 & 0.0317 & 0.0388 & 0.0519 \\
\hline $\mathrm{CO}(\mathrm{g} / \mathrm{s})$ & 0.0114 & 0.0130 & 0.0165 & 0.0196 & 0.0227 \\
\hline $\mathrm{CO}_{2}(\mathrm{~g} / \mathrm{s})$ & 2.93 & 4.17 & 5.41 & 6.04 & 6.76 \\
\hline $\mathrm{NO}_{\mathrm{x}}(\mathrm{g} / \mathrm{s})$ & 0.0080 & 0.0049 & 0.0066 & 0.0115 & 0.0178 \\
\hline $\mathrm{NO}_{\mathrm{x} 2}(\mathrm{~g} / \mathrm{s})$ & 0.0076 & 0.0047 & 0.0064 & 0.0110 & 0.0175 \\
\hline Lambda $(\lambda)$ & 1.26 & 1.36 & 1.40 & 1.41 & 1.40 \\
\hline
\end{tabular}

Figure 3 shows the $\mathrm{NO}_{\mathrm{X} 1}$ and $\mathrm{NO}_{\mathrm{X} 2}$ analyzer readings for each of the $50 \mathrm{~s}$ modes, and

Figure 4 shows the set and measured load. The sharp variations in the $\mathrm{NO}_{\mathrm{X}}$ readings were 
due to the data acquisition procedures used in this testing. The $\mathrm{NO}_{\mathrm{X}}$ analyzers were zeroed and spanned based on the peak $\mathrm{NO}_{\mathrm{X}}$ values reached during $\mathrm{NO}$ injections. This gave a low resolution measurement for the baseline $\mathrm{NO}_{\mathrm{X}}$ values shown in Figure 3. The accuracy of this measurement does not significantly effect the overall $\mathrm{NO}_{\mathrm{X}}$ conversion calculation, since the baseline engine emissions are all at least one order of magnitude smaller than the $\mathrm{NO}$ injection quantities. $\mathrm{NO}_{\mathrm{X}}$ readings for the $800 \mathrm{rpm}, 400 \mathrm{ft}-\mathrm{lb}$ set point appear to rise slightly over time relative to the initial $\mathrm{NO}_{\mathrm{X}}$ reading at this engine set point, with a standard deviation about the mean for this set point still less than $9 \%$. This may be due to an increase in the combustion temperature throughout the test, which can also be seen in the load plot in Figure 4. Continuous exhaust gas temperature was not monitored during this test but later measurements showed temperature rises on the order of $20^{\circ} \mathrm{F}$ when changing from 325 to $400 \mathrm{ft}-\mathrm{lb}$ load. During initial testing the set point of $400 \mathrm{ft}-\mathrm{lb}$ and $800 \mathrm{rpm}$ was attained, but when $\lambda$ was increased to 1.4 , the engine only attained an average of $384 \mathrm{ft}-\mathrm{lb}$. Figures 5, 6, and 7 show the baseline $\mathrm{HC}, \mathrm{CO}$, and $\mathrm{CO}_{2}$ emissions, respectively. 


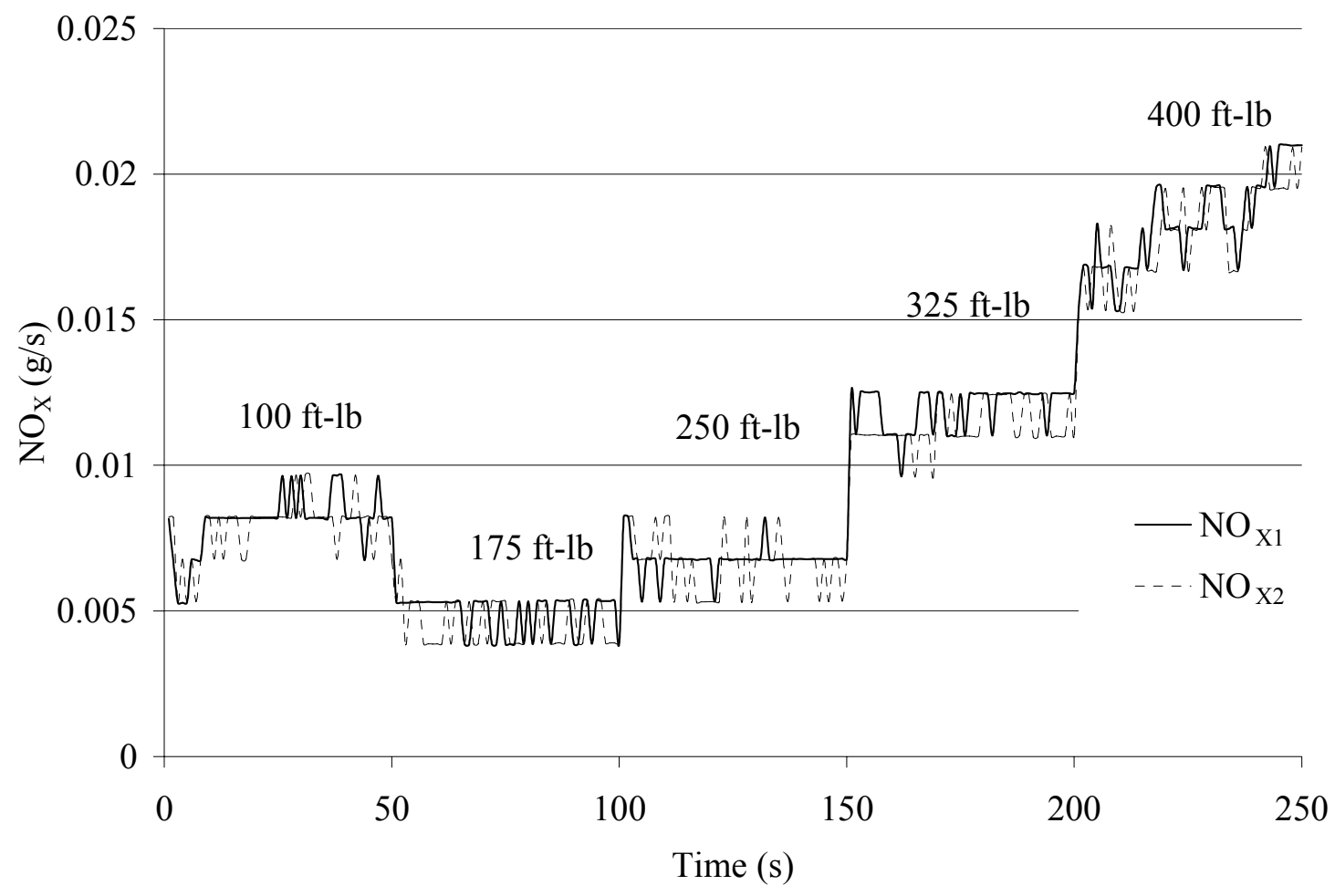

Figure 3: Baseline $\mathrm{NO}_{\mathrm{X}}$ emissions for the Cummins $\mathrm{L} 10 \mathrm{G}$ test engine, reported as $\mathrm{g} / \mathrm{s}$ of $\mathrm{NO}_{2}$, for varying loads at $800 \mathrm{rpm}$ 


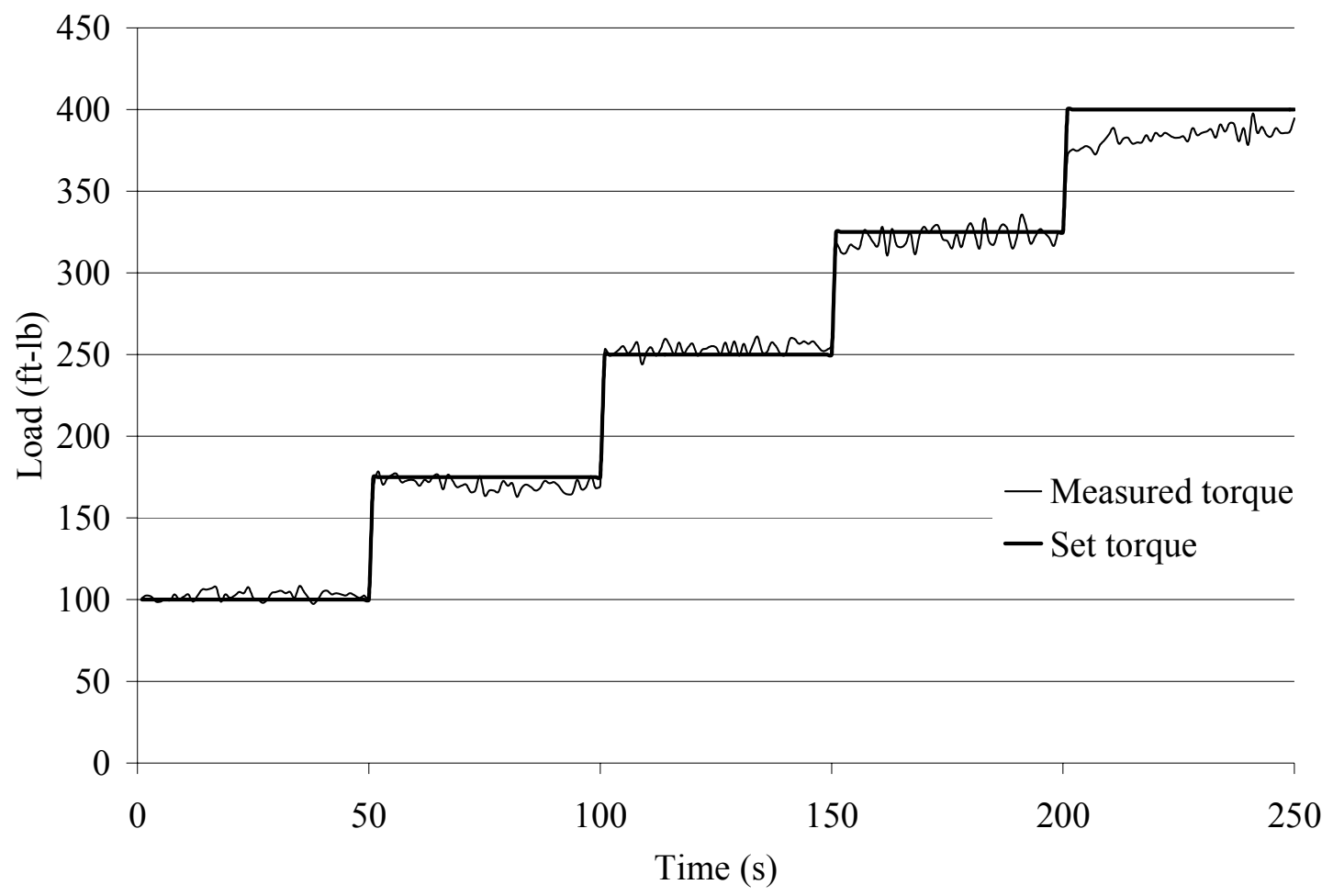

Figure 4: Set and measured load for the $800 \mathrm{rpm}$ set point

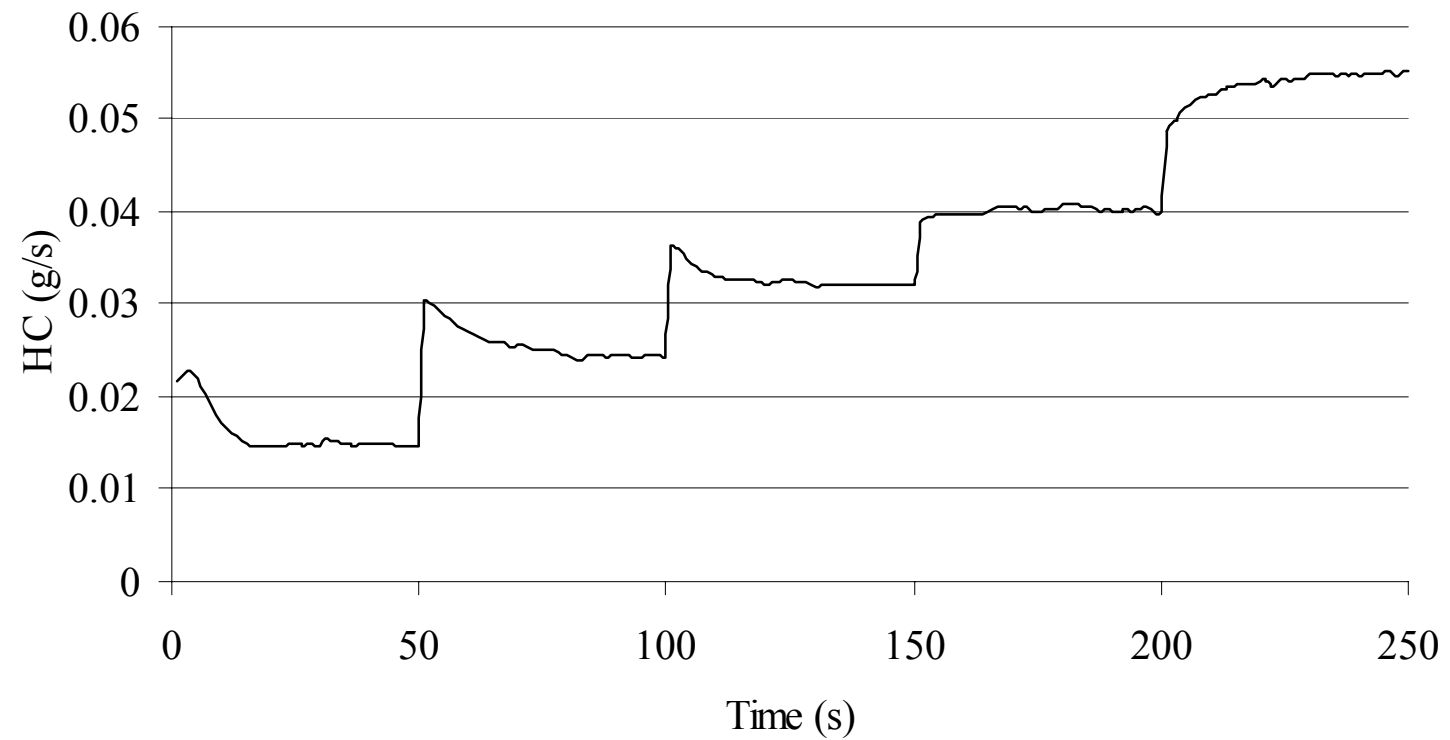

Figure 5: Baseline $\mathrm{HC}$ emissions for the Cummins L10 G test engine for varying loads at $800 \mathrm{rpm}$ 


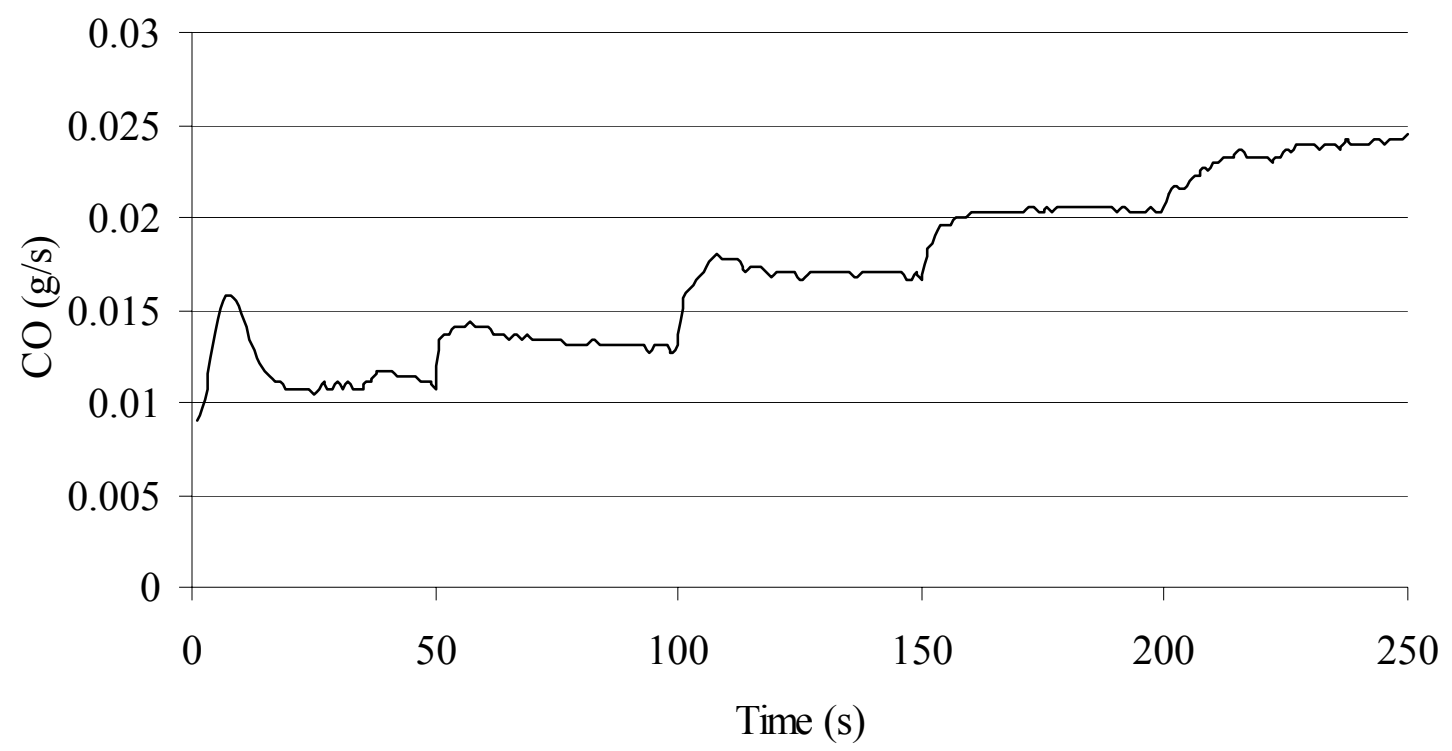

Figure 6: Baseline $\mathrm{CO}$ emissions for the natural gas engine for varying loads at $800 \mathrm{rpm}$

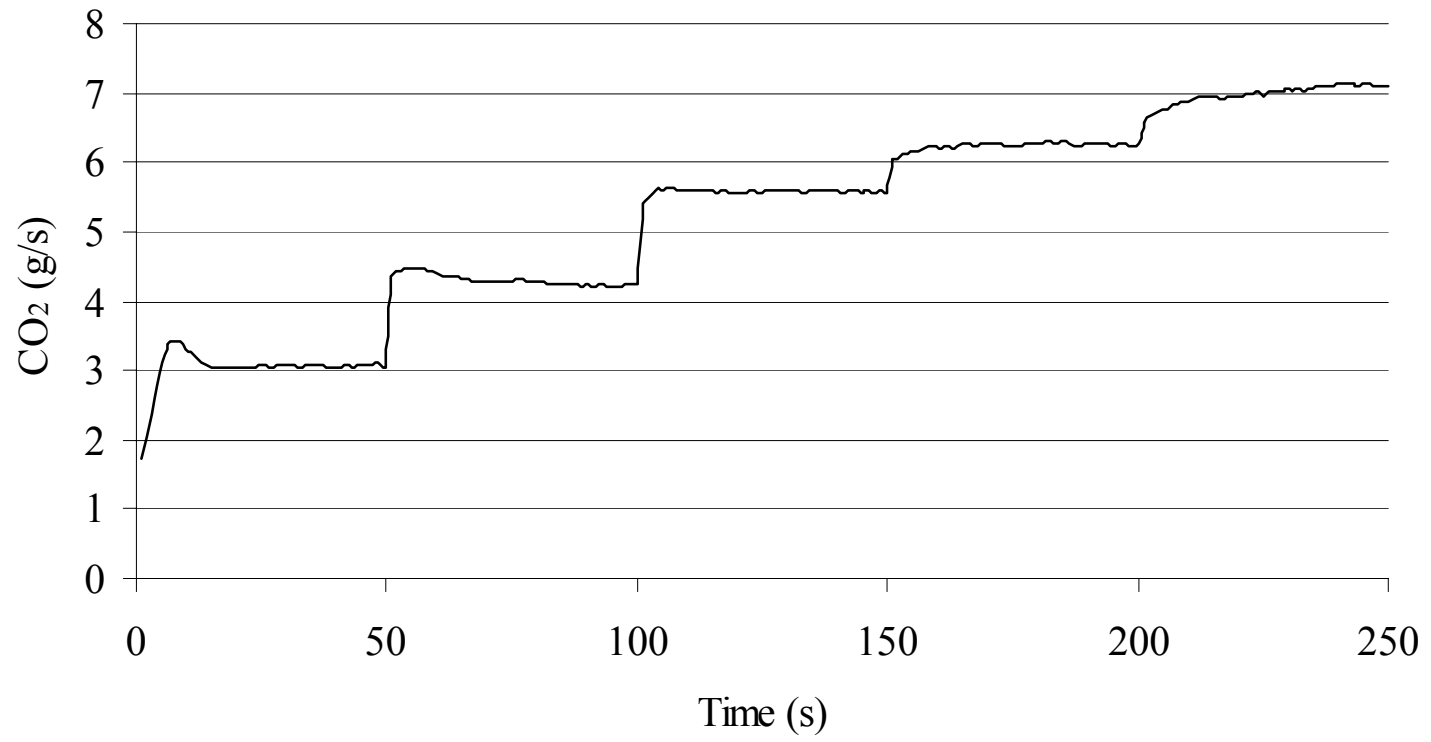

Figure 7: Baseline $\mathrm{CO}_{2}$ emissions for the natural gas engine for varying loads at $800 \mathrm{rpm}$ 
To simulate the SNR process, commercially available nitric oxide (NO, 98.8\% purity) injected into the engine air intake was used to mimic the $\mathrm{NO}_{\mathrm{X}}$ recirculation process. To inject a precise quantity of NO into the engine's intake air, a mass flow controller capable of injecting up to $100 \mathrm{slpm}$, or approximately $2 \mathrm{~g} / \mathrm{s}$, of $\mathrm{NO}$ was used. The $\mathrm{NO}_{\mathrm{X}}$ analyzers mentioned in Table 2 were employed to quantify the amount of $\mathrm{NO}_{\mathrm{X}}$ produced by the engine, with varying quantities of $\mathrm{NO}$ being injected, and also to validate the injection quantities and determine if noticeable percentages of NO are being converted after combustion has occurred. It should be noted that the $\mathrm{NO}_{\mathrm{X}}$ analyzers reported all values of $\mathrm{NO}_{\mathrm{X}}$ in terms of mass $\mathrm{NO}_{2}$ as per CFR regulations [30]. All values of $\mathrm{NO}_{\mathrm{X}}$ throughout this paper, other than those listed in Table 3 and Figure 3, which are reported as mass of $\mathrm{NO}_{2}$, are reported in terms of mass of $\mathrm{NO}$, which is a deviation from the CFR due to the makeup of the injection gas.

During the first test, varying concentrations of NO were injected at an engine speed of $800 \mathrm{rpm}$ and load of $400 \mathrm{ft}-\mathrm{lb}$, Table 4 . The engine was allowed to stabilize at $400 \mathrm{ft}-\mathrm{lb}$ and then NO was injected at rates varying from $0.39 \mathrm{~g} / \mathrm{s}$ to $1.82 \mathrm{~g} / \mathrm{s}$ for 20 second periods into the engine's air intake upstream of the fuel mixer (gas carburetor). Injecting for 20 second periods allowed the flow and the analyzer output to stabilize, while still minimizing the NO usage for each test. NO injection quantities in Table 4 represent the quantities as calculated by the mass flow controller. 
Table 4: Varying injection quantities of NO at constant engine speed and load

\begin{tabular}{||c|c|c|c|c||}
\hline \hline Speed & Load & $\begin{array}{c}\text { NO } \\
\text { injected }\end{array}$ & $\begin{array}{c}\text { NO in } \\
\text { intake }\end{array}$ & $\begin{array}{c}\text { Engine } \\
\text { intake flow }\end{array}$ \\
\hline Rpm & ft-lb & $\mathrm{g} / \mathrm{s}$ & $\mathrm{ppm}$ & slps \\
\hline 800 & 400 & 0.39 & 5,100 & 62 \\
\hline 800 & 400 & 0.78 & 10,000 & 62 \\
\hline 800 & 400 & 1.17 & 15,000 & 62 \\
\hline 800 & 400 & 1.56 & 20,000 & 62 \\
\hline 800 & 400 & 1.96 & 25,000 & 62 \\
\hline
\end{tabular}

On the second set of tests, engine speed and intake NO concentrations were kept constant, while varying the engine load, as seen in Table 5. At constant engine speed and varying loads, it is clear that the intake air flow rate fluctuates. To keep the percentage of NO in the intake air constant, the injected NO mass flow was altered accordingly. In doing this, it was predicted that better correlation between intake injection concentrations could be seen than by only holding the injection quantity constant. This held the molar fraction of NO in the intake constant for varying loads, which gave insight as to how conversion rates vary with temperature, knowing that higher loads lead to higher temperatures.

Table 5: Varying engine load at constant engine speed and injection quantities of NO

\begin{tabular}{||c|c|c|c|c||}
\hline Speed & Load & $\begin{array}{c}\text { NO } \\
\text { injected }\end{array}$ & $\begin{array}{c}\text { NO in } \\
\text { intake }\end{array}$ & $\begin{array}{c}\text { Engine } \\
\text { intake flow }\end{array}$ \\
\hline $\mathrm{Rpm}$ & $\mathrm{ft}-1 \mathrm{~b}$ & $\mathrm{~g} / \mathrm{s}$ & $\mathrm{ppm}$ & slps \\
\hline 800 & 100 & 0.64 & 25,000 & 21 \\
\hline 800 & 175 & 1.13 & 25,000 & 36 \\
\hline 800 & 250 & 1.44 & 25,000 & 47 \\
\hline 800 & 325 & 1.8 & 25,000 & 57 \\
\hline 800 & 400 & 1.94 & 25,000 & 62 \\
\hline
\end{tabular}




\section{EXPERMIENTAL RESULTS}

\subsection{VARIED CONCENTRATION AND CONSTANT CONCENTRATON RESULTS}

Figure 8 and Figure 9 show the results for the two tests. From these data it was clear that NO was decomposed during the combustion process at varying loads and injection quantities (note that the exhaust data represents the amount of NO before conversion). NO was injected into the exhaust to validate the injection quantities. This means that the data labeled Exhaust in Figure 8 and Figure 9 represent the engines emissions plus the NO injection without any conversion of $\mathrm{NO}$, whereas the Intake data represents the amount of NO after conversion.

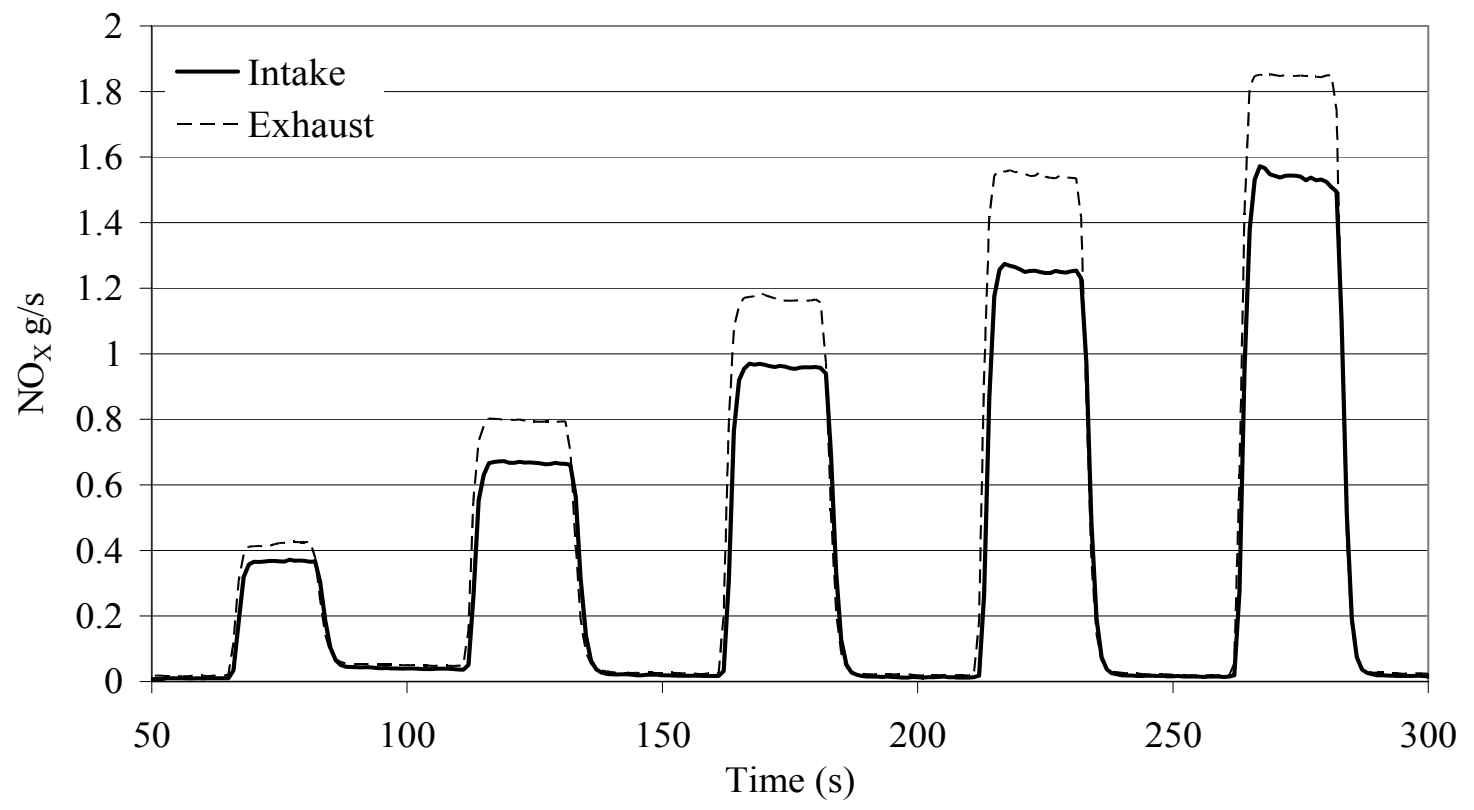

Figure 8: $\mathrm{NO}_{\mathrm{X}}$, reported as $\mathrm{NO}$, for lean combustion, at constant $800 \mathrm{rpm}$ engine speed and $400 \mathrm{ft}-\mathrm{lb}$ load, with varying NO injection quantities into the intake and exhaust 


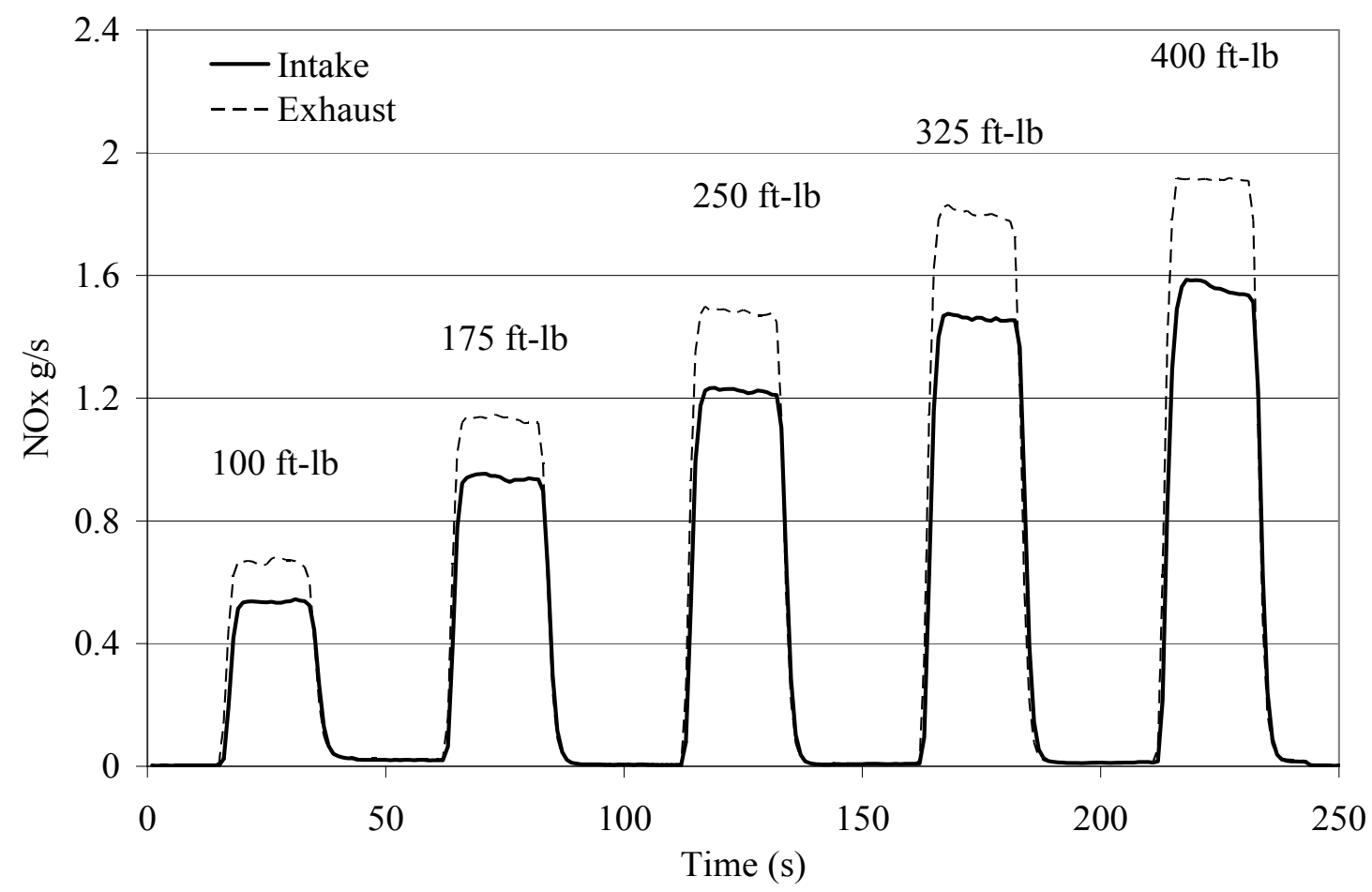

Figure 9: $\mathrm{NO}_{\mathrm{X}}$, reported as $\mathrm{NO}$ lean combustion at constant $800 \mathrm{rpm}$ engine speed and intake air NO injection concentrations of $25,000 \mathrm{ppm}$

The percentage of injected NO that was converted to oxidized products during the combustion process was calculated for each operating condition as follows. First, the average of the "flat" (steady state) portion of the two peaks, at each load, was calculated. The averages were taken over a ten second period, starting when the values came within $4 \%$ of the peak value. Then the average of the baseline (the $\mathrm{NO}_{\mathrm{x}}$ produced by the engine

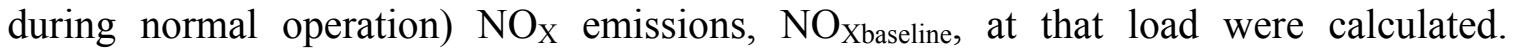
Subtracting the $\mathrm{NO}_{\text {Xbaseline }}$ from the $\mathrm{NO}_{\text {Xpeak_exhaust }}$ value represents the amount of $\mathrm{NO}$ injected by the NO mass flow controller. These value show good correlation with the values from the mass flow controller for both the varying and constant concentration 
cases, as seen in Table 6 and Table 7. They also show that an insignificant percent of NO is being reduced in the exhaust line and dilution tunnel measurement system.

Table 6: Comparison of mass flow controller and gas analyzer NO values for the constant load and varied concentration experiment

\begin{tabular}{||c|c|c|c|c||}
\hline Speed & $\begin{array}{c}\text { Set } \\
\text { load }\end{array}$ & $\begin{array}{c}\text { NO }_{\text {Xpeak_exhaust }}-\mathrm{NO}_{\text {Xbaseline }} \\
\text { analyzer reading }\end{array}$ & $\begin{array}{c}\text { Mass flow } \\
\text { controller }\end{array}$ & $\begin{array}{c}\text { Percent } \\
\text { difference }\end{array}$ \\
\hline $\mathrm{rpm}$ & $\mathrm{ft}-\mathrm{lb}$ & $\mathrm{g} / \mathrm{s}$ & $\mathrm{g} / \mathrm{s}$ & $\%$ \\
\hline 800 & 400 & 0.42 & 0.39 & 6.0 \\
\hline 800 & 400 & 0.79 & 0.78 & 1.2 \\
\hline 800 & 400 & 1.16 & 1.17 & 0.9 \\
\hline 800 & 400 & 1.55 & 1.56 & 1.1 \\
\hline 800 & 400 & 1.85 & 1.96 & 5.6 \\
\hline
\end{tabular}

Table 7: Comparison of mass flow controller and gas analyzer NO values for the constant concentration and varied load experiment

\begin{tabular}{||c|c|c|c|c||}
\hline Speed & $\begin{array}{c}\text { Set } \\
\text { load }\end{array}$ & NO $_{\text {Xpeak exhaust }}-\mathrm{NO}_{\text {Xbaseline }}$ & $\begin{array}{c}\text { Mass flow } \\
\text { controller }\end{array}$ & $\begin{array}{c}\text { Percent } \\
\text { difference }\end{array}$ \\
\hline $\mathrm{rpm}$ & $\mathrm{ft}-\mathrm{b}$ & $\mathrm{g} / \mathrm{s}$ & $\mathrm{g} / \mathrm{s}$ & $\%$ \\
\hline 800 & 100 & 0.66 & 0.65 & 1.9 \\
\hline 800 & 175 & 1.13 & 1.13 & 0.3 \\
\hline 800 & 250 & 1.48 & 1.48 & 0.2 \\
\hline 800 & 325 & 1.79 & 1.80 & 0.1 \\
\hline 800 & 400 & 1.91 & 1.94 & 1.3 \\
\hline
\end{tabular}

Next the $\mathrm{NO}_{\text {Xbaseline }}$ was subtracted from the $\mathrm{NO}_{\text {Xpeak_exhaust }}$ value. This value represents the amount of $\mathrm{NO}_{\mathrm{X}}$ that was seen by the $\mathrm{NO}_{\mathrm{X}}$ analyzer due to the injection with conversion during the combustion process. This value was then taken as a percentage of the original amount of NO that was injected, to find the percentage of NO converted $\left(\eta_{c}\right)$ 
at each load and injection quantity as seen below in Equation 7. This is a similar method to that used by Krutzsch et al. [2].

$$
\eta_{c}=1-\frac{\left(N O_{\text {Xpeak_int ake }}-N O_{\text {Xbaseline }}\right)}{\left(N O_{\text {Xpeak_exhaust }}-N O_{\text {Xbaseline }}\right)}
$$

The NO decomposition percentages for the data given in Figure 8 and Figure 9 are shown in Figure 10 and Figure 11, respectively. Error bars represent $\pm 2.5 \%$ inaccuracy in the NO measurement, which sums to $\pm 5.0 \%$ overall inaccuracy when subtracting these values as shown in Equation 7. It was observed that the $\mathrm{NO}$ conversion rates varied between 14 to $20 \%$ as seen in Figure 10 for varying injection quantities, and between 18 to $23 \%$ for a constant $25,000 \mathrm{ppm} \mathrm{NO}$ concentration at $800 \mathrm{rpm}$ and varying loads, as seen in Figure 11.

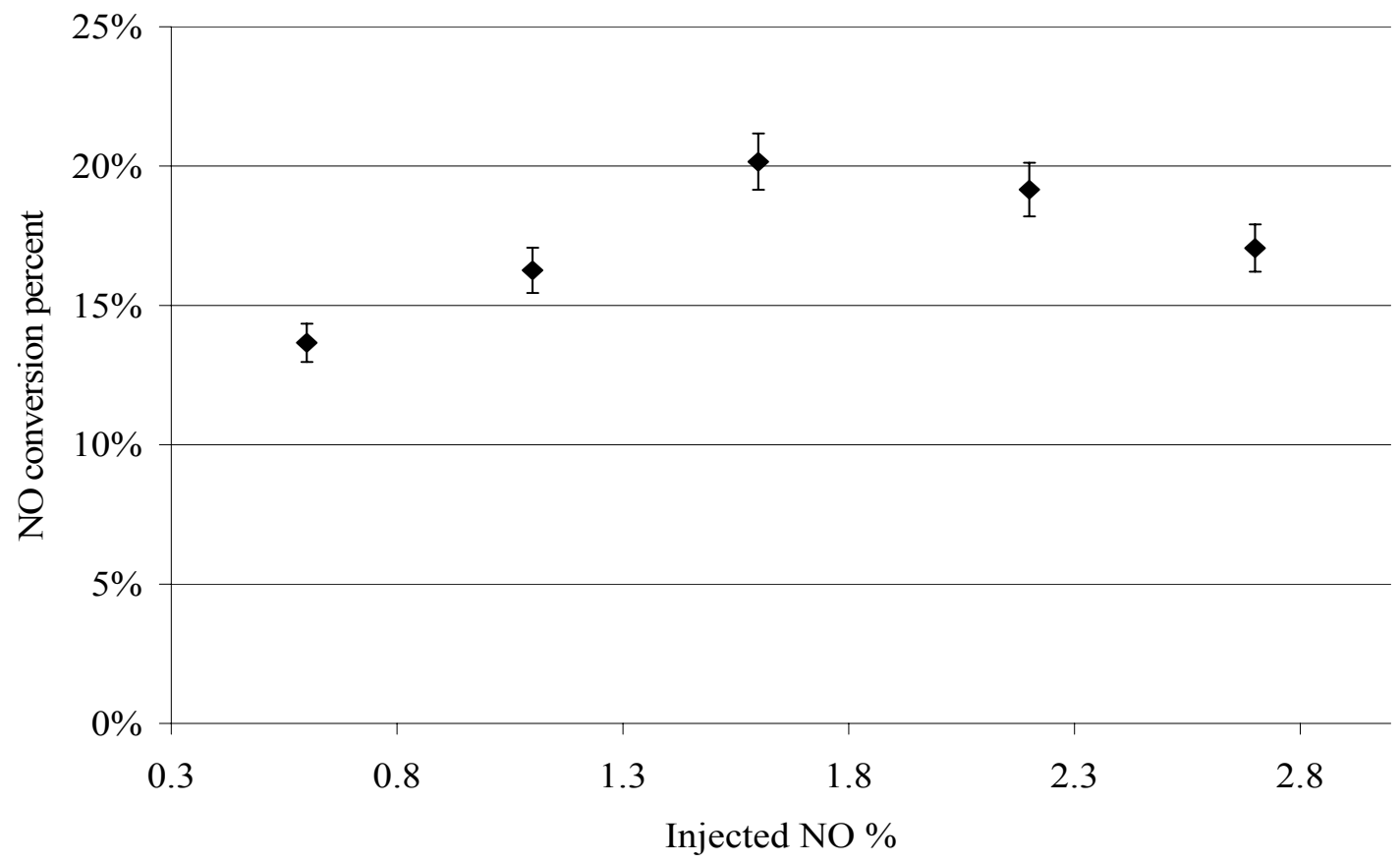

Figure 10: NO decomposition for varying NO quantities at constant engine speed and load 


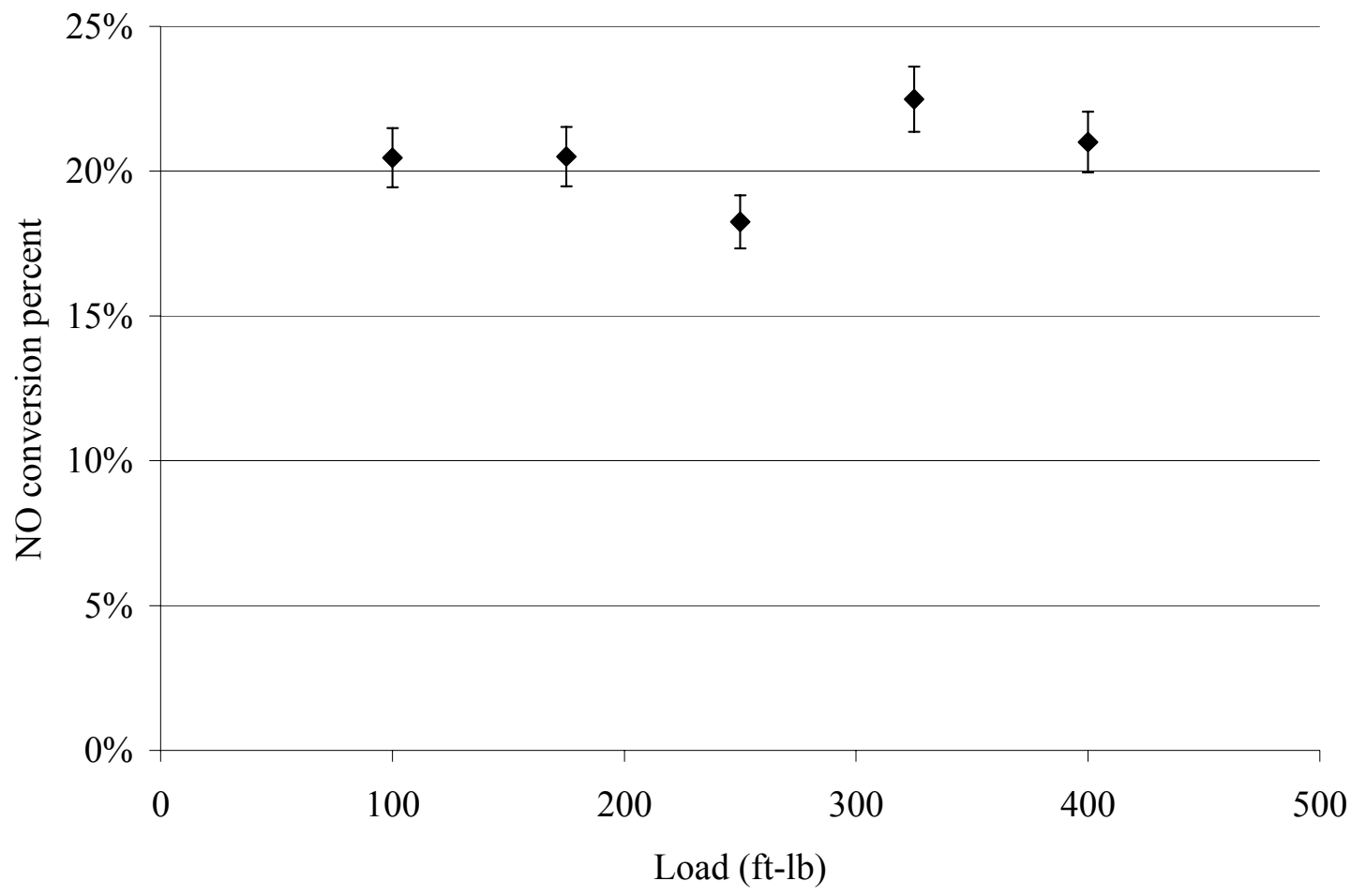

Figure 11: NO decomposition vs. engine load for constant concentration and engine speed

The results shown in Figure 11 suggest NO conversion is not a strong function of engine load. The inability to hold the air-fuel ratio at the 100 and $175 \mathrm{ft}-1 \mathrm{~b}$ load levels may have skewed these results. The richer air-fuel ratios may have given more NO conversion than would have been seen at leaner levels, due to the increased HC levels. NO injection effects on other emissions are represented in Figure 12 and Figure 13. These results show $20 \%$ reductions in $\mathrm{HC}$ emissions and a decrease in $\mathrm{CO}$ emissions during $\mathrm{NO}$ injections. 


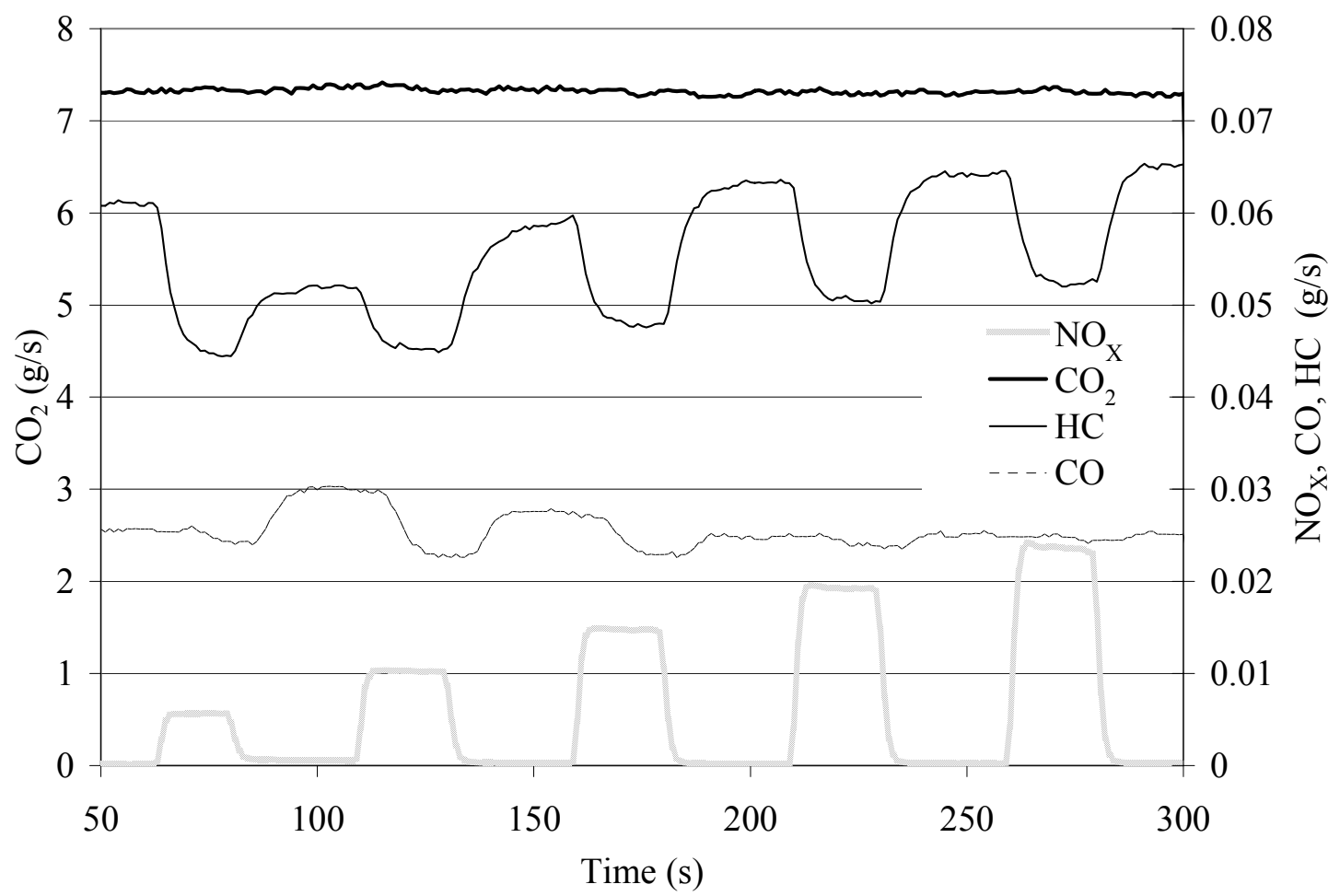

Figure 12: Result of varying concentration NO injections on other emissions for the constant $800 \mathrm{rpm}$ and $400 \mathrm{ft}-\mathrm{lb}$ load experiment 


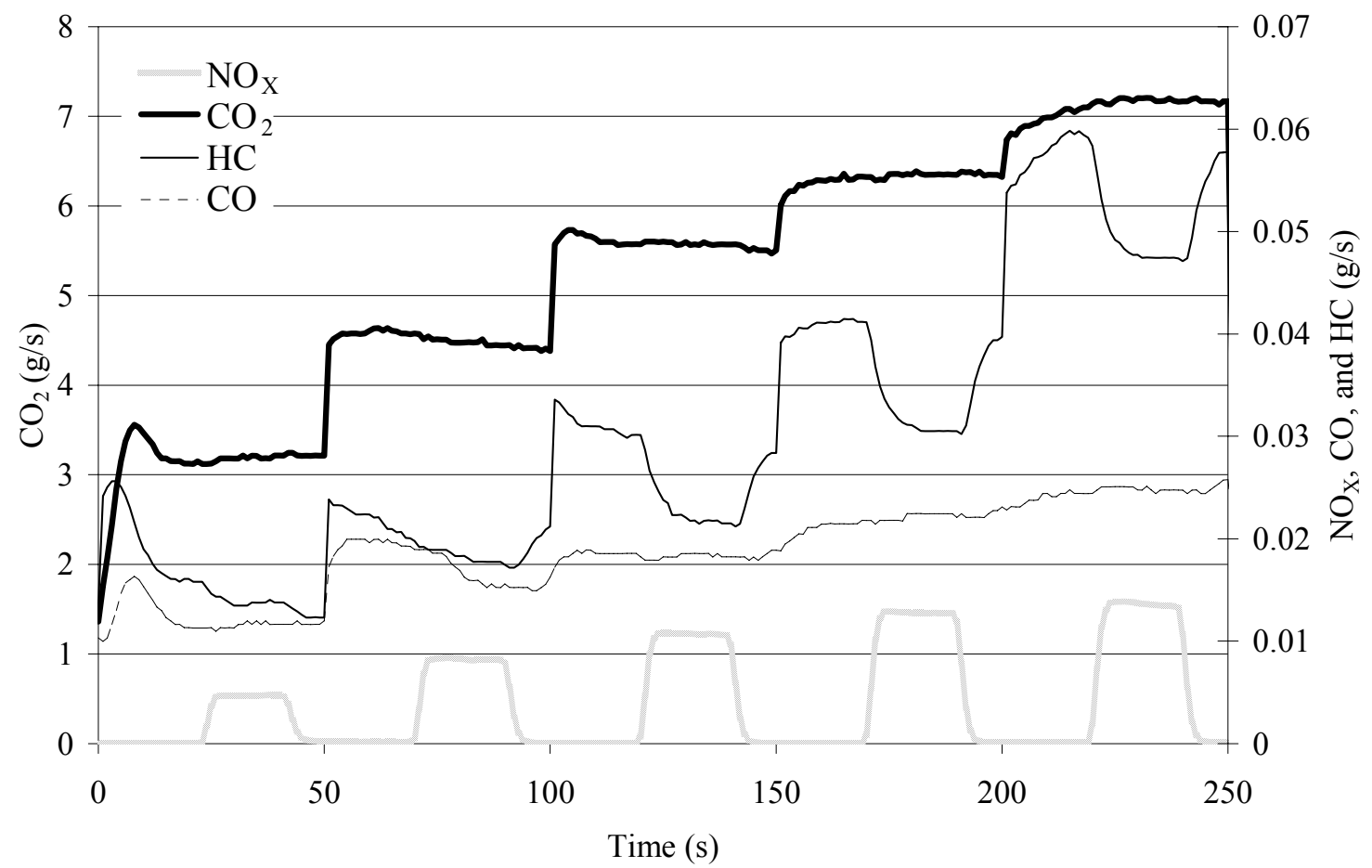

Figure 13: Result of NO injections on other emissions for the $800 \mathrm{rpm}$ constant concentration and varied engine load experiment

\subsection{REPEATABILITY}

Figure 14 shows the $800 \mathrm{rpm} 400 \mathrm{ft}-\mathrm{lb}$ engine set point data for each of the NO injection experiments shown in Figure 8 and Figure 9. The Exhaust 1 and Intake 1 data represent the varied NO concentration test, and Exhaust 2 and Intake 2 represent the constant concentration test. This set point was chosen to show repeatability, because the same quantity of NO was injected in each separate test on different test days. The $\lambda$ variation for the 5 experiments (baseline and exhaust and intake injections for each NO injection experiment) was 1.38 to 1.42 and the day-to-day average engine torque variation was 385 to $402 \mathrm{ft}-\mathrm{lb}$. These variations also represent the maximum variation of $\lambda$ and torque 
throughout all of the testing. Therefore, the percentage variation in the NO conversion efficiency due to day-to-day testing variations should not exceed what is shown here for any other test points. The reason for the large torque variation at this set point, as shown in Figure 4, was discussed previously. $\lambda$ and torque were measured over the entire mode for each engine set point. NO injections did slightly affect $\lambda$, but $\lambda$ remained within this range. Engine speed variation from day-to-day was negligible. The NO conversion for the varied concentration experiment and constant concentration experiment were $17 \%$ and $21 \%$ respectively.

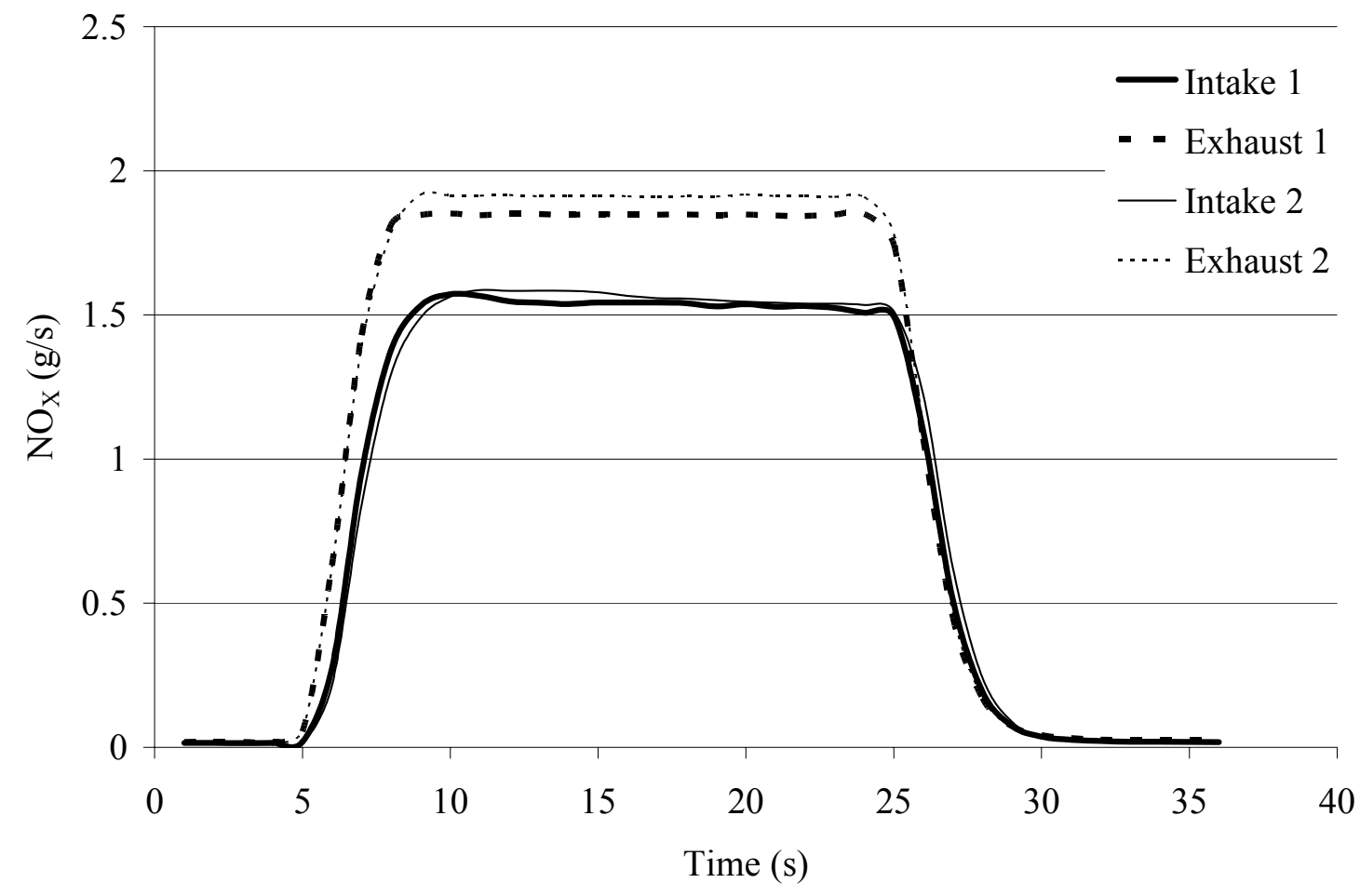

Figure 14: Two sets of NO injections at $800 \mathrm{rpm}$ and $400 \mathrm{ft}-1 \mathrm{~b}$ load on different test days 


\section{CHEMICAL KINETIC MODELING}

On a microscopic scale, one may consider the reduction of NO in a "packet" of gas as the flame front approaches, consumes, and leaves behind the reactants. In this work, it was assumed that a packet was initially at the temperature and pressure due to compression; clearly little reaction occurs at this temperature. The temperature was modeled to rise rapidly with the flame temperature, and the pressure modeled to rise in sympathy, by holding the specific volume of the gases constant. The reactions that occur during this time must consider both the flame chemistry (changing composition) and the elevated temperature. In the post-flame period, the gas composition will change less, but the temperature will remain elevated, which can be mimicked well by maintaining a constant specific volume. What was not modeled is the change in pressure (and hence temperature) due to the combustion of other packets of gas before and after the combustion of the packet in question. It is acknowledged, therefore, that this modeling represents a simplification, but it can provide trends.

CHEMKIN was used to model these packets of gas in a simulation of a closed homogenous batch reactor held at constant volume. A range of temperatures were used with the assumption that the highest temperature of any packet would not exceed the adiabatic flame temperature of $1900 \mathrm{~K}$ as calculated below. This type of model is zerodimensional because it models a single packet of gases, and does not account for flame front motion or volume change due to piston motion. One-dimensional models use measured in-cylinder pressure as a function of time or crank angle to find an average 
temperature trace. The unburned gas temperature history is calculated assuming the unburned fuel-air mixture is adiabatically compressed and expanded. These temperatures and pressures are then used to model the chemical reaction kinetics [31]. Two-zone models involve a burned and unburned gas region. One-dimensional two-zone models use the average pressure and calculated average temperature as a function of time to find heat transfer correlations for the two-zones [32]. A zero-dimensional model was preferred over the two-zone because the assumption of average temperature and pressure necessary for this type of model would not increase the overall accuracy of the model over a zerodimensional one as described here. If detailed spatial relationships for temperature and pressure were known then a symmetric two-dimensional model may be of use. The fact that this packet is modeled over a range of actual combustion temperatures allows the model to be valid over the entire cylinder volume when a range of values is being considered. In 1998, Dodge et al. [33] found that a similar zero-dimensional model well predicted the $\mathrm{NO}_{\mathrm{X}}$ emission from lean burn natural gas engines.

\subsection{FLAME TEMPERATURE CALCULATION}

To estimate the temperature and pressure at which these reactions occur, an adiabatic flame temperature calculation was performed for each of the varying A/F ratios and EGR cases. The compression stroke was modeled as an isentropic compression. The gases at an initial temperature and pressure of $298 \mathrm{~K}$ and $1 \mathrm{~atm}$, were compressed to a temperature of $679 \mathrm{~K}$ and pressure of 23.9 atm. The initial pressure of 1 atm was chosen to be representative of an engine operating without turbo boost pressure. This is the case for the Cummins L10 when operating under low speed, $800 \mathrm{rpm}$ conditions. To account for 
valve timing, a 90\% volumetric efficiency was assumed, which yielded a pressure of 21.5 atm, before reactions have occurred.

\subsubsection{LEAN BURN CASE}

Emissions data at $800 \mathrm{rpm}$ and $400 \mathrm{ft}-\mathrm{lb}$ load were used as shown in Table 3, to calculate the adiabatic flame temperature for the engine test point used for simulation. NO injections only further decreased the calculated flame temperature, but by an amount less than $2 \%$, which was considered negligible by the author. An energy balance was performed assuming an adiabatic flame. Enthalpy values for reactants and products were taken from the JANAF tables [34], and Table 8 and Table 9 show the enthalpies and temperatures used in calculating the adiabatic flame temperature of $1910 \mathrm{~K}$. This temperature was rounded down to $1900 \mathrm{~K}$ during modeling, to evenly distribute the data. It should be noted that the enthalpy of $\mathrm{NO}_{2}$ was used when calculating the enthalpy of $\mathrm{NO}_{\mathrm{X}}$, which gives a slightly higher flame temperature.

Table 8: Reactant enthalpies (intake composition)

\begin{tabular}{||c|c|c|c||}
\hline & $\mathrm{g} / \mathrm{s}$ & $\mathrm{h} \mathrm{(kcal/mol)} \mathrm{@} \mathrm{679} \mathrm{K}$ & $\mathrm{h}(\mathrm{kcal} / \mathrm{s})$ \\
\hline $\mathrm{CH}_{4}$ & 3.01 & -10.8 & -2.03 \\
\hline $\mathrm{O}_{2}$ & 17.2 & 3.03 & 1.63 \\
\hline $\mathrm{N}_{2}$ & 53.3 & 3.17 & 6.04 \\
\hline & & sum & 5.63 \\
\hline
\end{tabular}


Table 9: Product enthalpies (exhaust composition)

\begin{tabular}{||c|c|c|c||}
\hline & $\mathrm{g} / \mathrm{s}$ & $\mathrm{h}(\mathrm{kcal} / \mathrm{mol}) @ 1910 \mathrm{~K}$ & $\mathrm{H}(\mathrm{kcal} / \mathrm{s})$ \\
\hline $\mathrm{CO}$ & 0.027 & -12.2 & -0.012 \\
\hline $\mathrm{CO}_{2}$ & 7.04 & -70.3 & -11.3 \\
\hline $\mathrm{H}_{2} 0(\mathrm{gas})$ & 6.78 & -36.2 & -13.7 \\
\hline $\mathrm{NO}_{\mathrm{X}}$ & 0.212 & 30.0 & 0.138 \\
\hline $\mathrm{CH}_{4}$ & 0.039 & 22.2 & 0.055 \\
\hline $\mathrm{N}_{2}$ & 53.2 & 14.5 & 27.7 \\
\hline $\mathrm{O}_{2}$ & 5.87 & 14.7 & 2.70 \\
\hline & & sum & 5.63 \\
\hline
\end{tabular}

\subsubsection{STOICHIOMETRIC CASE}

To find an estimate of the maximum flame temperature reached during the stoichiometric combustion of methane $\left(\mathrm{CH}_{4}\right)$, an adiabatic flame temperature calculation was performed assuming no dissociation of molecules. Again, the contribution of NO in the initial mixture was assumed negligible in the calculation of stoichiometric flame temperature.

Table 10: Reactant enthalpies for stoichiometric combustion of $\mathrm{CH}_{4}$

\begin{tabular}{||c|c|c|c||}
\hline \hline & mole fraction & $\mathrm{h}(\mathrm{kcal} / \mathrm{mol}) @ 679 \mathrm{~K}$ & $\mathrm{~h}(\mathrm{kcal})$ \\
\hline $\mathrm{CH}_{4}$ & 0.09 & -10.8 & -1.03 \\
\hline $\mathrm{O}_{2}$ & 0.20 & 3.03 & 0.60 \\
\hline $\mathrm{N}_{2}$ & 0.71 & 3.17 & 2.24 \\
\hline & & sum & 1.82 \\
\hline
\end{tabular}

Table 11: Reactant enthalpies for stoichiometric combustion of $\mathrm{CH}_{4}$

\begin{tabular}{||c|c|c|c||}
\hline & mole fraction & $\mathrm{h}(\mathrm{kcal} / \mathrm{mol}) @ 2342 \mathrm{~K}$ & $\mathrm{~h}(\mathrm{kcal})$ \\
\hline $\mathrm{CO}_{2}$ & 0.10 & -60.1 & -5.8 \\
\hline $\mathrm{H}_{2} 0$ (gas) & 0.19 & -29.4 & -5.6 \\
\hline $\mathrm{N}_{2}$ & 0.71 & 18.6 & 13.2 \\
\hline & & sum & 1.83 \\
\hline
\end{tabular}




\subsubsection{EGR AND RICH CASES}

For the rich case the maximum flame temperature was calculated to be $2374 \mathrm{~K}$ based on no dissociation of products. For the lean burn with 20\% EGR case, the flame temperature was calculated assuming no dissociation and only $\mathrm{CO}_{2}$ and $\mathrm{H}_{2} \mathrm{O}$ as the EGR constituents. The values used for $\mathrm{CO}_{2}$ and $\mathrm{H}_{2} \mathrm{O}$ for this case will be discussed in subsequent sections. For $20 \%$ EGR the flame temperature calculated was $1990 \mathrm{~K}$. It should be noted that EGR should lower the flame temperature, but the flame temperature appears to have increased from the lean burn case to the lean burn with EGR case. This is because of the assumptions that were made, and the use of actual data for the lean with no EGR case. The value of $1900 \mathrm{~K}$ was taken when modeling both lean burn and lean burn with EGR, to simplify the test matrices.

\subsection{CHEMKIN MODELING}

\subsubsection{LEAN BURN CASE}

The closed homogeneous batch reactor within CHEMKIN was used to model chemical reactions occurring at a constant specific volume. CHEMKIN computations were performed in two sets, both at a relative air-fuel ratio of 1.4 , corresponding to an air-fuel ratio of 24. First the concentration of NO in the initial mixture of gases was varied while holding the temperature at $1700 \mathrm{~K}$ and constant volume. To model this process completely a temperature range varying from $1300 \mathrm{~K}$ to the adiabatic flame temperature of $1900 \mathrm{~K}$ should be modeled, but in this case since only the general trend of $\mathrm{NO}_{\mathrm{X}}$ conversion with varying concentration is being examined, only one mid-range 
temperature was modeled. The initial pressure was chosen to be representative of the pressure which would occur from the isentropic compression of the gases in the engine cylinder, followed by a constant volume process which brings the packet of gas up to the flame temperature assumed here to be $1700 \mathrm{~K}$, with no chemical reactions occurring. After assuming a 90\% volumetric efficiency this yielded a pressure of 53.9 atm at 1700 $\mathrm{K}$. The pressure was left to vary slightly as the molar quantity changed in the cylinder as a result of reaction. The initial mole fractions of each mixture of $\mathrm{CH}_{4}, \mathrm{O}_{2}, \mathrm{~N}_{2}$, and $\mathrm{NO}$ are shown in Table 12, note the injection amount in ppm is before fuel is added.

Table 12: Mole fractions of mixtures used in modeling the constant volume process

\begin{tabular}{||c|c|c|c|c||}
\hline $\begin{array}{c}\text { NO injection } \\
\text { amount (ppm) }\end{array}$ & \multicolumn{4}{|c||}{ Mole fractions of initial mixtures } \\
\hline & $\mathrm{NO}$ & $\mathrm{CH}_{4}$ & $\mathrm{O}_{2}$ & $\mathrm{~N}_{2}$ \\
\hline 0 & 0 & 0.0697 & 0.2047 & 0.7256 \\
\hline 625 & 0.0006 & 0.0697 & 0.2045 & 0.7252 \\
\hline 1,250 & 0.0012 & 0.0697 & 0.2044 & 0.7248 \\
\hline 1,720 & 0.0016 & 0.0696 & 0.2043 & 0.7244 \\
\hline 2,500 & 0.0023 & 0.0696 & 0.2042 & 0.7239 \\
\hline 5,000 & 0.0047 & 0.0694 & 0.2037 & 0.7222 \\
\hline 10,000 & 0.0093 & 0.0691 & 0.2028 & 0.7188 \\
\hline 20,000 & 0.0186 & 0.0684 & 0.2008 & 0.7121 \\
\hline \hline
\end{tabular}

Second, the initial mole fractions of $\mathrm{CH}_{4}, \mathrm{O}_{2}, \mathrm{~N}_{2}$, and $\mathrm{NO}$ in the mixture were held constant throughout each computation. Reactions were constrained by maintaining a constant specific volume. An array of initial temperatures ranging from $1300 \mathrm{~K}$ to 1900 $\mathrm{K}$ was used as an input to model the NO versus time while the temperature during each computation was kept constant. Here the simulation pressure for each temperature was calculated in the same manner as mentioned previously, and is shown in Table 13 for 
each temperature. For this large range of temperatures, and therefore reaction rates, the time step for the CHEMKIN solver was varied for each temperature, along with the end time of each solution. To find a representative time in which complete combustion could be defined for each temperature, plots of $\mathrm{CH}_{4}$ versus time were examined in the chemical kinetic modeling results section of this thesis. After the $\mathrm{CH}_{4}$ levels dropped to near zero values at each temperature, the time for this reaction to occur was then at least doubled when finding an appropriate end time for the solution. The end times, the time at which at least $98 \%$ of the $\mathrm{CH}_{4}$ has been depleted, and solver time step, the time step used in the CHEMKIN code finite difference approximations, used for lean combustion modeling are shown in Table 13. Note, that at $1300 \mathrm{~K}$ and $1450 \mathrm{~K}$, the end time and time step were increased by one order of magnitude when $\mathrm{NO}$ was modeled as part of the initial mixture of gases for the stoichiometric and EGR cases. This is because of the reduced reaction rates of $\mathrm{CH}_{4}$ and $\mathrm{NO}_{\mathrm{X}}$ that modeling exhibits.

Table 13: Temperature and initial pressure with CHEMKIN solver time step and end times for lean combustion

\begin{tabular}{||c|c|c|c||}
\hline $\begin{array}{c}\text { Temperature } \\
(\mathrm{K})\end{array}$ & $\begin{array}{c}\text { Initial Pressure } \\
(\mathrm{atm})\end{array}$ & $\begin{array}{c}\text { End time } \\
(\mathrm{s})\end{array}$ & $\begin{array}{c}\text { Solver time } \Delta \mathrm{t} \\
(\mathrm{s})\end{array}$ \\
\hline 1300 & 41.2 & $1.00 \mathrm{E}-02$ & $1.00 \mathrm{E}-07$ \\
\hline 1450 & 46.0 & $1.00 \mathrm{E}-03$ & $1.00 \mathrm{E}-08$ \\
\hline 1600 & 50.7 & $1.00 \mathrm{E}-03$ & $1.00 \mathrm{E}-08$ \\
\hline 1750 & 55.5 & $1.00 \mathrm{E}-04$ & $1.00 \mathrm{E}-09$ \\
\hline 1900 & 60.3 & $1.00 \mathrm{E}-04$ & $1.00 \mathrm{E}-09$ \\
\hline
\end{tabular}




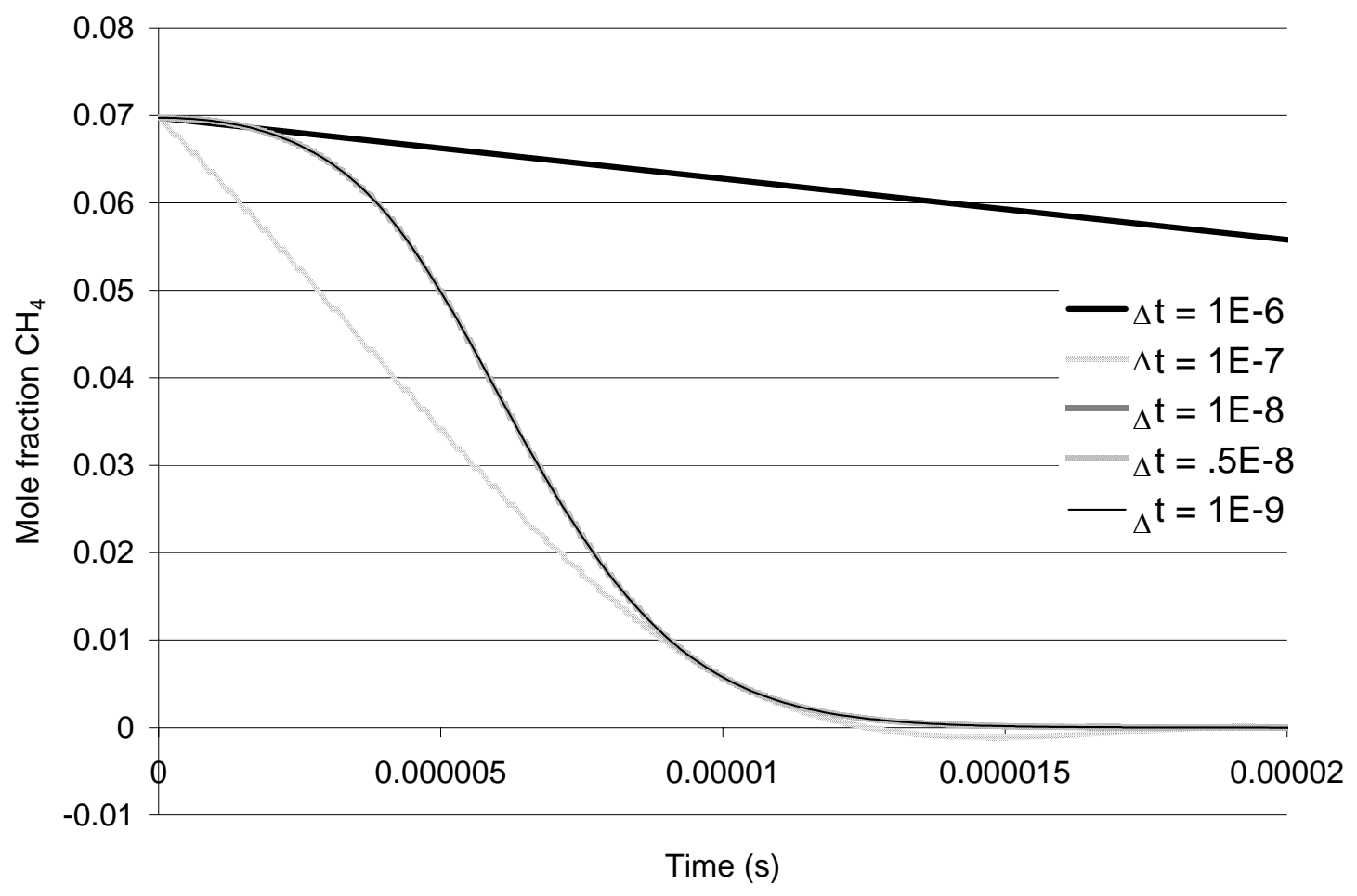

Figure 15: Check for solution independence of time step

Figure 15 shows $\mathrm{CH}_{4}$ as a function of time for a lean $(\lambda=1.4)$ mixture without NO. The solver time step was decreased until the solution showed solver time step independence.

\subsubsection{STOCHIOMETRIC CASE}

When modeling stoichiometric combustion with $\mathrm{NO}$ in the intake air stream, the NO concentration was held constant at 25,000 ppm (before fuel was added), while varying the temperature of reaction from $1300 \mathrm{~K}$ to the adiabatic flame temperature for stoichiometric combustion of $2350 \mathrm{~K}$. Stoichiometric combustion has a relative air-fuel ratio of 1 , which corresponds to an air-fuel ratio of 17.3 for methane combustion. These values were used when calculating the initial mole fractions of the initial mixture of gases for modeling purposes. For this large range of temperatures, and therefore reaction rates, the time step for the CHEMKIN solver was varied for each temperature, along with the 
end time of each solution, as was described previously. The end times and solver time steps used for stoichiometric combustion modeling are shown in

Table 14: Temperature and initial pressure with CHEMKIN solver time step and end times for stoichiometric combustion

\begin{tabular}{||c|c|c|r||}
\hline $\begin{array}{c}\text { Temperature } \\
(\mathrm{s})\end{array}$ & $\begin{array}{c}\text { Initial Pressure } \\
(\mathrm{atm})\end{array}$ & $\begin{array}{c}\text { End time } \\
(\mathrm{s})\end{array}$ & $\begin{array}{c}\text { Solver time } \Delta \mathrm{t} \\
(\mathrm{s})\end{array}$ \\
\hline 1300 & 41.2 & $1.00 \mathrm{E}-02$ & $1.00 \mathrm{E}-07$ \\
\hline 1450 & 46.0 & $1.00 \mathrm{E}-03$ & $1.00 \mathrm{E}-08$ \\
\hline 1600 & 50.7 & $1.00 \mathrm{E}-03$ & $1.00 \mathrm{E}-08$ \\
\hline 1750 & 55.5 & $1.00 \mathrm{E}-04$ & $1.00 \mathrm{E}-09$ \\
\hline 1900 & 60.3 & $1.00 \mathrm{E}-04$ & $1.00 \mathrm{E}-09$ \\
\hline 2050 & 65.0 & $1.00 \mathrm{E}-04$ & $1.00 \mathrm{E}-09$ \\
\hline 2200 & 69.8 & $1.00 \mathrm{E}-05$ & $1.00 \mathrm{E}-10$ \\
\hline 2350 & 74.5 & $1.00 \mathrm{E}-06$ & $1.00 \mathrm{E}-11$ \\
\hline
\end{tabular}

\subsubsection{EGR CASE}

Before modeling it was not clear as to how EGR will affect the SNR process. Plans to run the natural gas engine with EGR and the SNR process have been put into place at the time of completion of this thesis. The purpose of this modeling is to predict if EGR will increase the $\mathrm{NO}_{\mathrm{X}}$ conversion efficiency, and therefore increase the overall efficiency of the SNR process.

\subsubsection{LEAN BURN WITH EGR CASE}

To model the SNR process with EGR exhaust gas composition data was taken from the Cummins L10 natural gas engine, Table 3. It was assumed that SNR, or the simulated NO injections, will not play a major role in the exhaust gas composition from a steady state 
standpoint, but it should be noted that this will affect exhaust gas composition. To simplify the computational matrices only the $20 \%$ EGR case was modeled. This is a general estimate of the amount of EGR that may be needed to maximize the conversion efficiencies, and values ranging from 0 to $40 \%$ have been shown to be acceptable levels in a spark ignited engine [14]. $20 \%$ of the intake air was assumed to be replaced with EGR at standard conditions. The air-fuel ratio was then based on assuming that the $20 \%$ EGR would not displace a significant amount of $\mathrm{O}_{2}$ in an engine operating under lean conditions. Therefore a relative air-fuel of 1.4 would result in the same amount of fueling as the lean burn case without EGR. Tables 15, 16, and 17 show the resulting mixtures of EGR, intake air, $\mathrm{NO}$, and $\mathrm{CH}_{4}$. These tables together represent the method for calculating the initial mixture of gases that would be entering an engine cylinder with EGR and SNR. This method was defined in this manner to model the methods of injecting NO and mixing fuel that are already in place for experimentation on the Cummins L10 natural gas engine. Table 17 represents the mixture of gases that was modeled in CHEMKIN.

Table 15: EGR and intake air mixture for lean combustion with EGR

\begin{tabular}{||c|c||}
\hline Species & Mole fraction \\
\hline $\mathrm{NO}$ & $4.44 \mathrm{E}-05$ \\
\hline $\mathrm{CH}_{4}$ & $2.60 \mathrm{E}-04$ \\
\hline $\mathrm{O}_{2}$ & $1.91 \mathrm{E}-01$ \\
\hline $\mathrm{N}_{2}$ & $7.69 \mathrm{E}-01$ \\
\hline $\mathrm{CO}$ & $7.14 \mathrm{E}-05$ \\
\hline $\mathrm{CO}_{2}$ & $1.18 \mathrm{E}-02$ \\
\hline $\mathrm{H}_{2} 0$ & $2.86 \mathrm{E}-02$ \\
\hline $\mathrm{NO}_{2}$ & $7.83 \mathrm{E}-06$ \\
\hline
\end{tabular}


Table 16: EGR, intake air, and NO mixture for lean combustion with EGR

\begin{tabular}{||c|c||}
\hline Species & Mole fraction \\
\hline $\mathrm{NO}$ & $2.50 \mathrm{E}-02$ \\
\hline $\mathrm{CH}_{4}$ & $2.53 \mathrm{E}-04$ \\
\hline $\mathrm{O}_{2}$ & $1.86 \mathrm{E}-01$ \\
\hline $\mathrm{N}_{2}$ & $7.49 \mathrm{E}-01$ \\
\hline $\mathrm{CO}$ & $6.96 \mathrm{E}-05$ \\
\hline $\mathrm{CO}_{2}$ & $1.15 \mathrm{E}-02$ \\
\hline $\mathrm{H}_{2} \mathrm{O}$ & $2.79 \mathrm{E}-02$ \\
\hline $\mathrm{NO}_{2}$ & $7.63 \mathrm{E}-06$ \\
\hline
\end{tabular}

Table 17: EGR, intake air NO, and fuel mixture for lean combustion with EGR

\begin{tabular}{||c|c||}
\hline Species & Mole fraction \\
\hline $\mathrm{NO}$ & $2.27 \mathrm{E}-02$ \\
\hline $\mathrm{CH}_{4}$ & $9.31 \mathrm{E}-02$ \\
\hline $\mathrm{O}_{2}$ & $1.69 \mathrm{E}-01$ \\
\hline $\mathrm{N}_{2}$ & $6.80 \mathrm{E}-01$ \\
\hline $\mathrm{CO}$ & $6.32 \mathrm{E}-05$ \\
\hline $\mathrm{CO}_{2}$ & $1.05 \mathrm{E}-02$ \\
\hline $\mathrm{H}_{2} \mathrm{O}$ & $2.53 \mathrm{E}-02$ \\
\hline $\mathrm{NO}_{2}$ & $6.92 \mathrm{E}-06$ \\
\hline
\end{tabular}

\subsubsection{RICH BURN CASE}

For rich burn a relative air-fuel ratio of 0.9 was used. This yielded the following initial mixture of gases, Table 18.

Table 18: Initial mixture of gases for the rich burn case

\begin{tabular}{||c|c||}
\hline Species & Mole fraction \\
\hline $\mathrm{NO}$ & 0.022 \\
\hline $\mathrm{CH}_{4}$ & 0.102 \\
\hline $\mathrm{O}_{2}$ & 0.193 \\
\hline $\mathrm{N}_{2}$ & 0.683 \\
\hline
\end{tabular}




\section{CHEMICAL KINETIC MODELING RESULTS}

\subsection{LEAN BURN CASE}

Using a complete engine stroke yields a time reference on the order of milliseconds. NO mole fraction versus time is shown in Figure 16 for a time scale much longer than this. The curve shows varying amounts of initial NO concentration, which are held at $1700 \mathrm{~K}$ and $53.9 \mathrm{~atm}$ for $50 \mathrm{~s}$, which was three orders of magnitude longer than the time it takes to complete a stroke of the piston. The solver time step used was $0.01 \mathrm{~s}$.

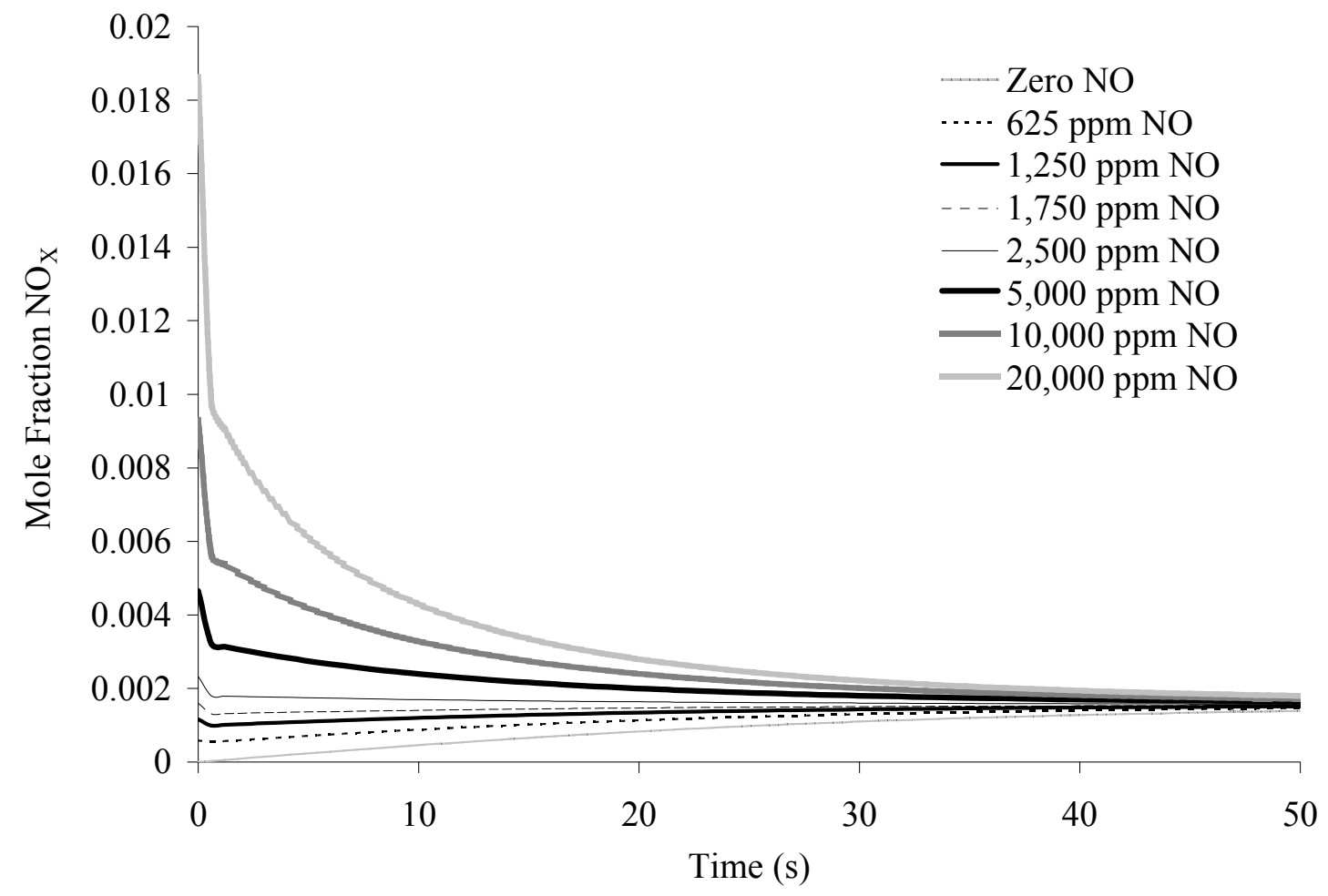

Figure 16: Mole fraction of $\mathrm{NO}_{\mathrm{X}}$, reported as $\mathrm{NO}$, for varying initial gas mixtures on a large time scale 
The highest line represents and initial concentration of $\mathrm{NO}$ in a mixture of $\mathrm{CH}_{4}, \mathrm{O}_{2}, \mathrm{~N}_{2}$, and NO, with NO making up 20,000 ppm of this mixture. This concentration corresponds to a 0.0186 mole fraction of $\mathrm{NO}$ if the relative air-fuel ratio is 1.4 and the concentrations of $\mathrm{N}_{2}$ and $\mathrm{O}_{2}$ in air were taken as 0.78 and 0.22 , respectively. The lowest curve represents the normal initial conditions for a natural gas engine (excluding residual gases) with only $\mathrm{CH}_{4}$, air, and no initial $\mathrm{NO}$ concentration.

In each of the curves shown in Figure 16, excluding the zero and $625 \mathrm{ppm}$ NO concentration levels, the mole fraction of NO drops, within the first second of reaction time. The actual time in which these conversions occur, due to the computational error for the large time step used, is on the order of milliseconds as seen in Figure 17. After this initial drop the rates of reaction slow until equilibrium is reached. With this particular mixture the equilibrium level is approximately 0.0016 mole fraction. The objective of this varied NO concentration model was to compare the varied concentrations experiments of Figure 8 and Figure 10. The experimental results do show slightly lower conversions at lower injection concentrations, but since the modeling was done after the experimentation quantities below this equilibrium level of .0016 mole fraction level were not tested.

After the effects of varying in cylinder concentration were modeled in CHEMKIN, the effects of constant concentration and varied temperature on NO conversion rates were explored in more detail, similar to experimental data in Figure 9. One method of determining the conversion rate of $\mathrm{NO}$ in the CHEMKIN models proposed by the author is the "line method." This is a simple method that is based on the assumption that there is 
a certain time interval in which all reactions are occurring, and after that all reactions will freeze. The second method proposed by the author is the " $\mathrm{CH}_{4}$ Method." This method assumes that after a certain percent of the $\mathrm{CH}_{4}$ is consumed, then the $\mathrm{NO}_{\mathrm{X}}$ conversion has also ceased.

\subsubsection{LINE METHOD}

More refined time steps and shorter end times were then tested for initial temperatures ranging from 1300 to $1900 \mathrm{~K}$ and initial $\mathrm{NO}$ concentration of $25,000 \mathrm{ppm}$ or 0.0233 mole fraction for this particular initial mixture of $\mathrm{CH}_{4}, \mathrm{O}_{2}, \mathrm{~N}_{2}$, and $\mathrm{NO}$ at a relative air-fuel ratio of 1.4. As with all models, the solutions were checked for solver time step independence. Figure 17 to Figure 20 show $\mathrm{NO}, \mathrm{NO}_{2}, \mathrm{CH}_{4}$, and $\mathrm{NO}_{\mathrm{X}}$ as a function of time for these small time scales, and Figure 21 shows $\mathrm{NO}_{\mathrm{X}}$ as a function of time on a larger time scale. These figures indicate that $\mathrm{NO}_{2}$ is being formed on the same time scale in which complete combustion of $\mathrm{CH}_{4}$ occurs. $\mathrm{NO}_{2}$ levels then decrease significantly. Conversely, $\mathrm{NO}$ levels drop rapidly then rise slightly as $\mathrm{NO}_{2}$ is depleted. This behavior leads to the conversion of $\mathrm{NO}_{\mathrm{X}}$ as seen in Figure 20.

The vertical dashed line in Figure 20 was put in place to clarify the area of interest in the combustion process. The results to the left of the dashed line represent high reaction rates which are occurring in a time frame on the order of magnitude of $10^{\circ}$ before and $10^{\circ}$ after TDC. For an engine running at $800 \mathrm{rpm}$ this corresponds to a time of 4 milliseconds. The results to the right of the dashed line represent reactions that would theoretically occur if the gases stayed at high temperatures. Although on this time scale it may seem that 
reactions have stopped occurring and $\mathrm{NO}_{\mathrm{X}}$ levels have reached some equilibrium level, this is not the case. The reactions rates have just slowed to a different rate which is not visible in Figure 20, but can easily be seen in Figure 21.

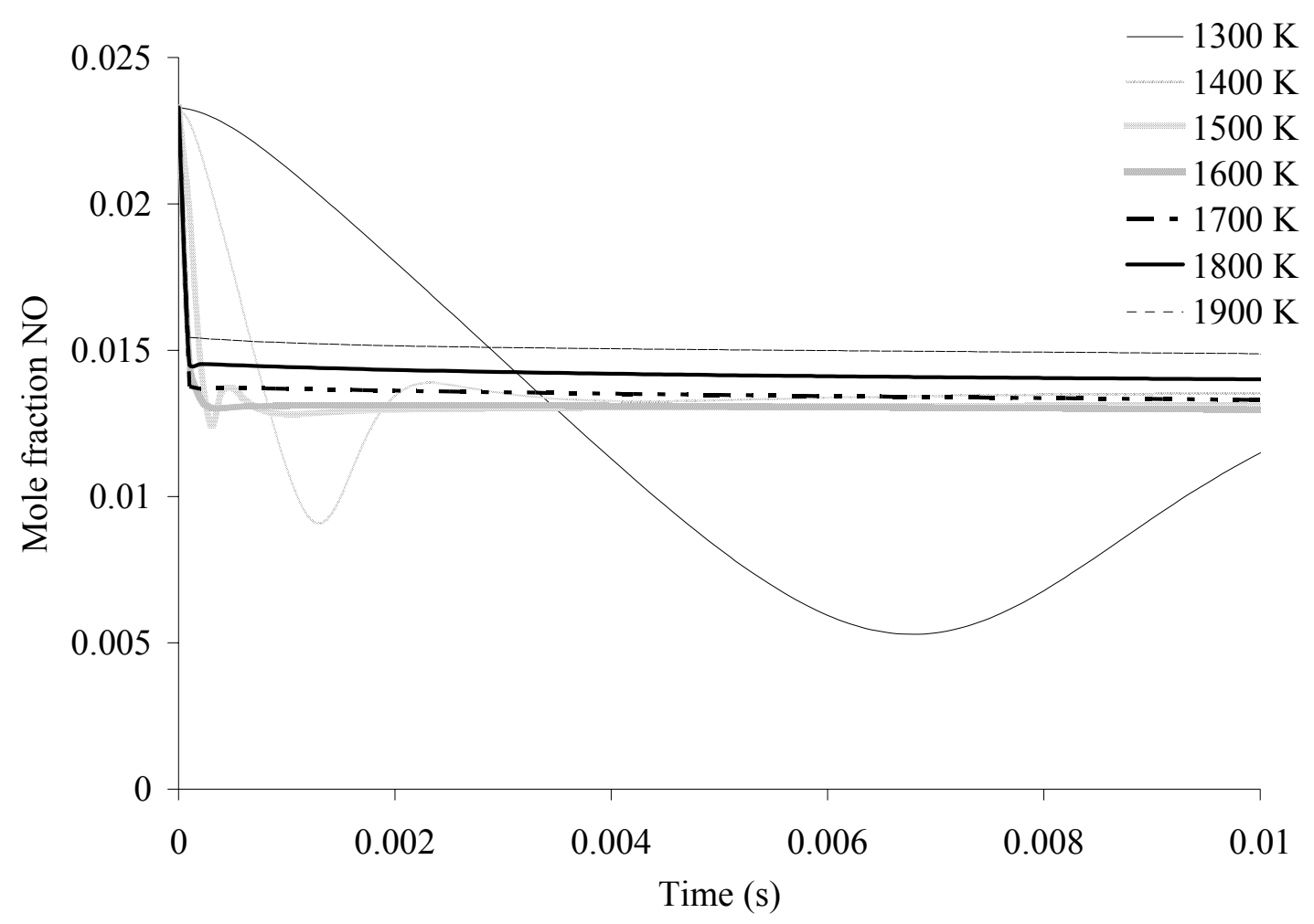

Figure 17: Mole fraction of NO for constant temperature processes 


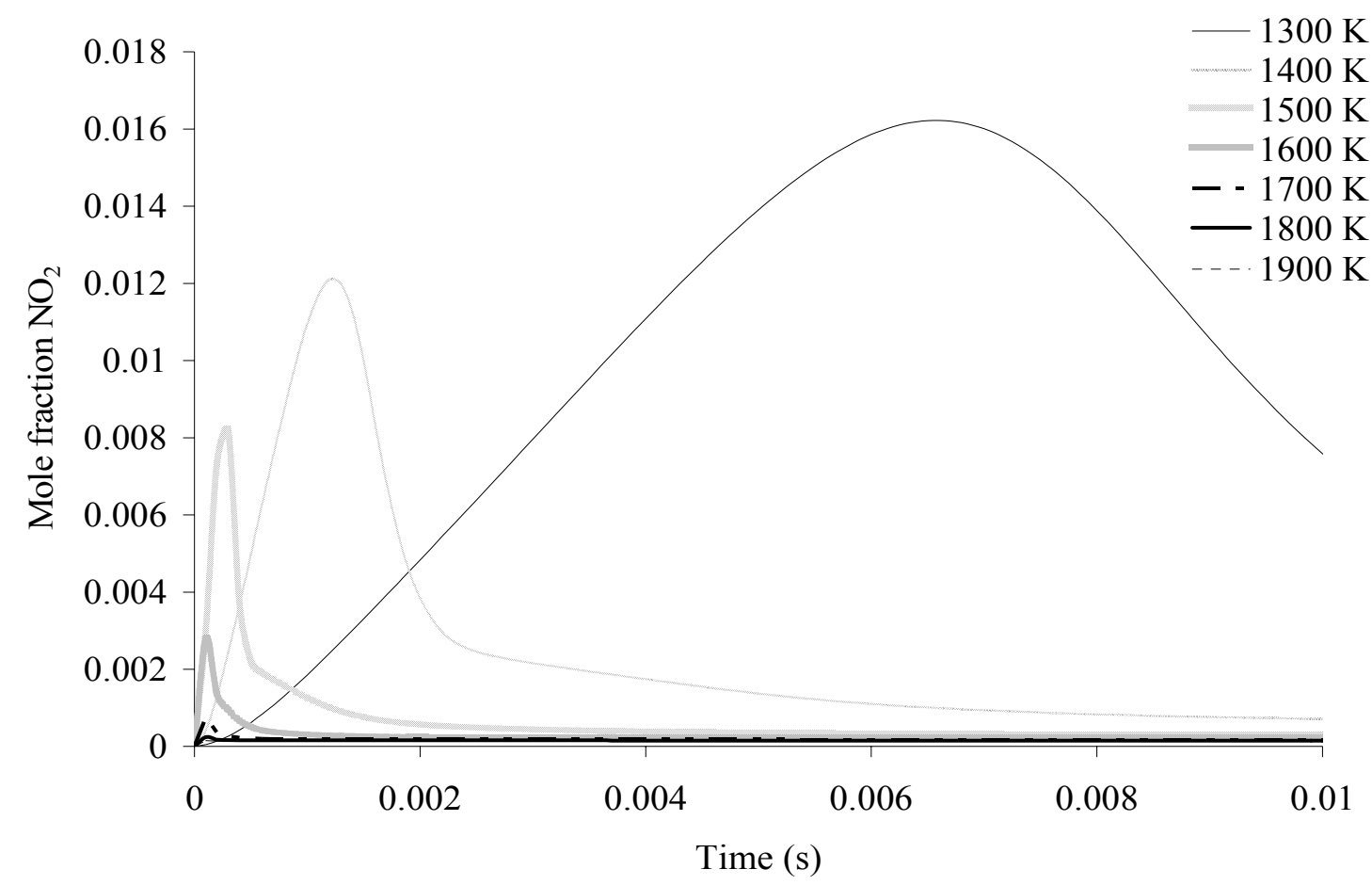

Figure 18: Mole fraction of $\mathrm{NO}_{2}$ for constant temperature processes

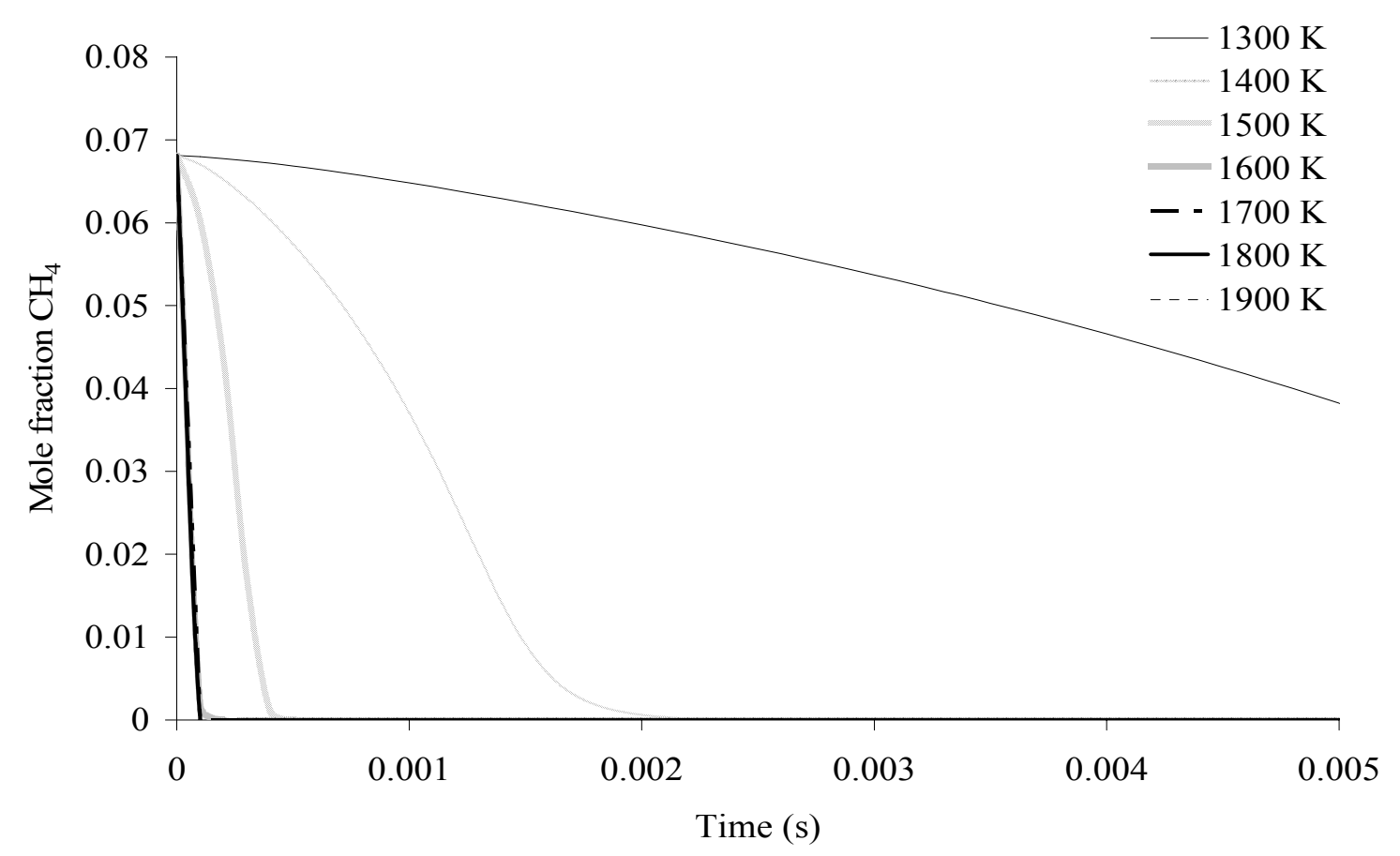

Figure 19: Mole fraction of $\mathrm{CH}_{4}$ for constant temperature processes 


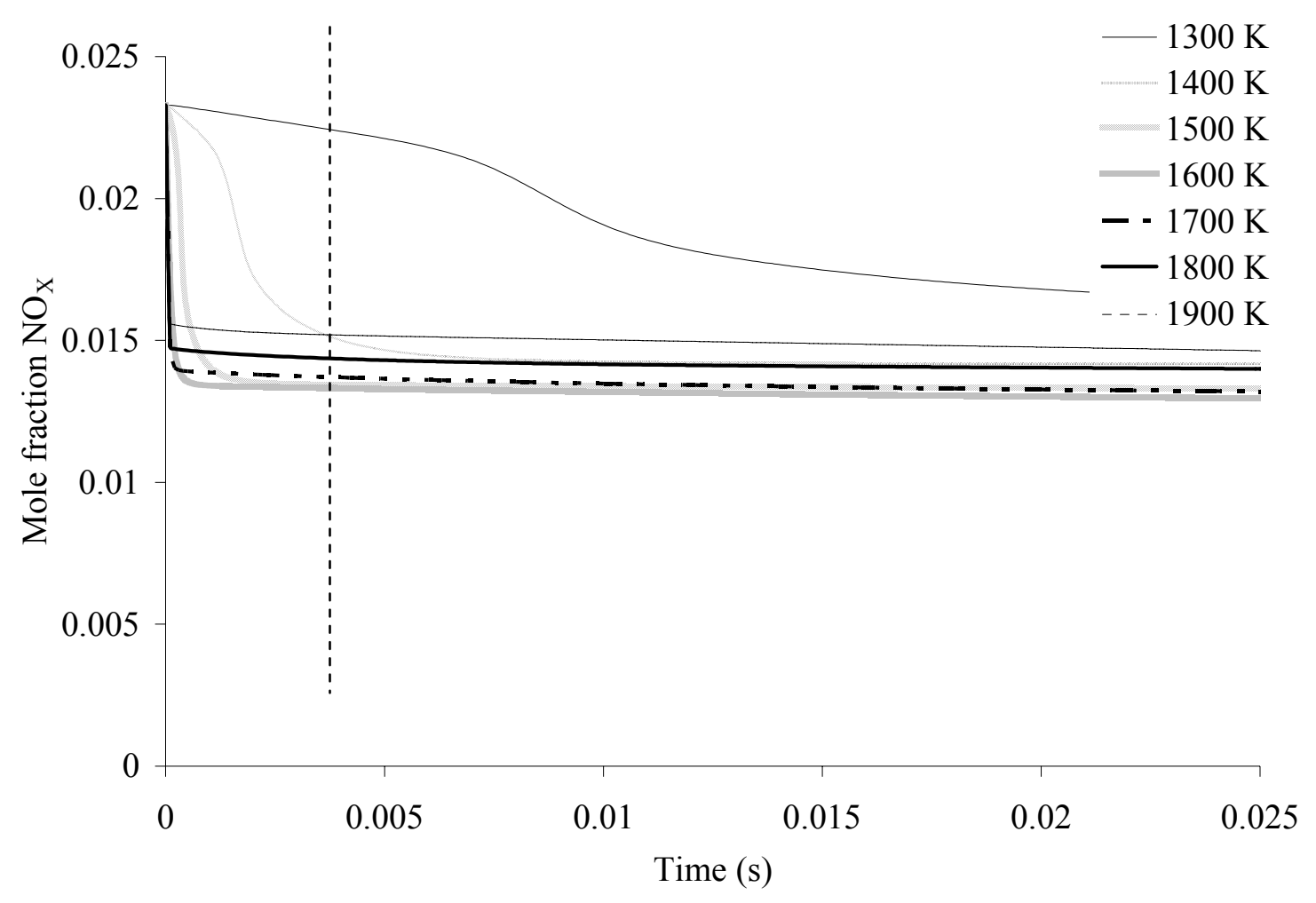

Figure 20: Mole fraction of $\mathrm{NO}_{\mathrm{X}}$, reported as $\mathrm{NO}$, for constant temperature processes on a small time scale 


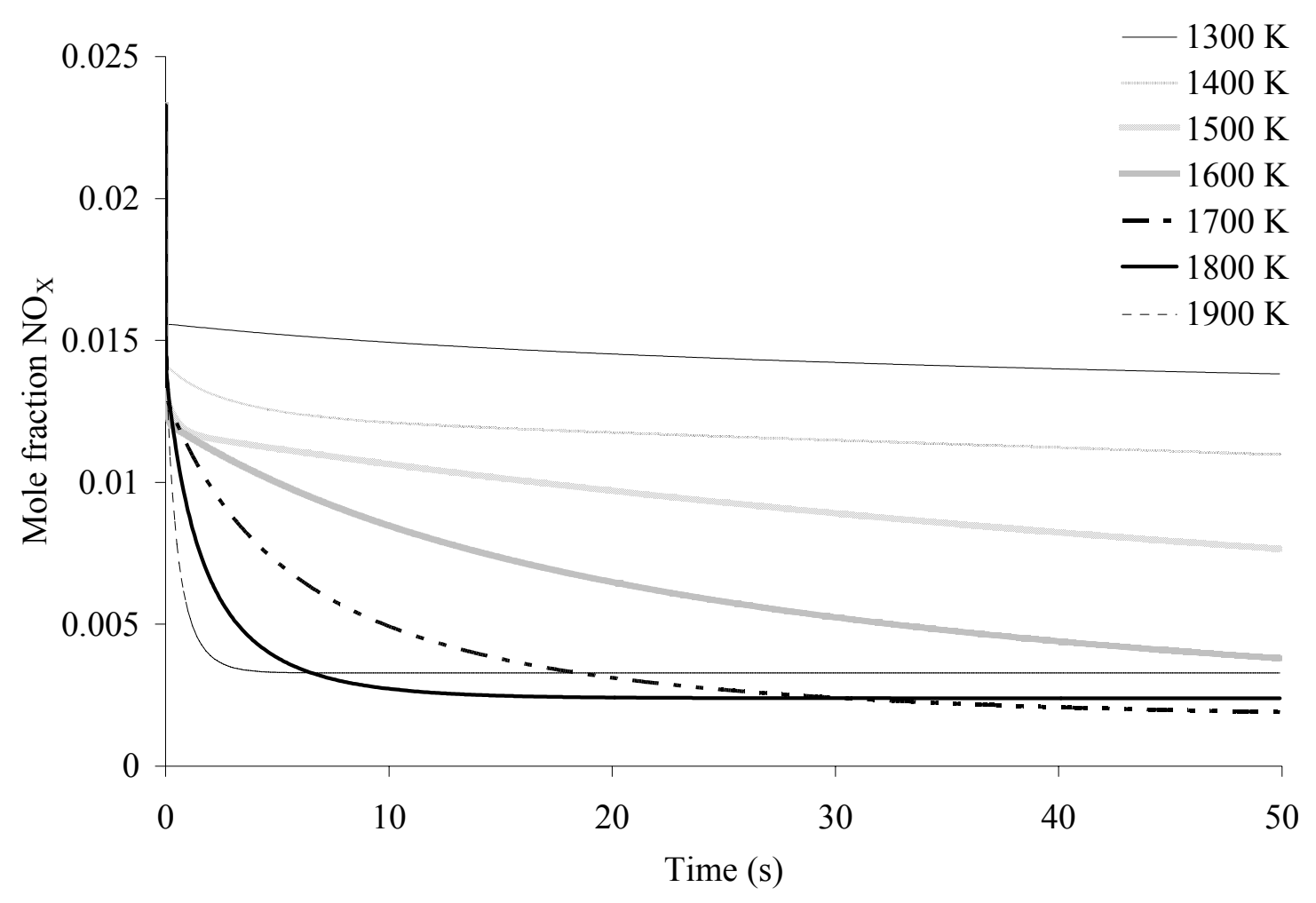

Figure 21: Mole fraction of $\mathrm{NO}_{\mathrm{X}}$, reported as $\mathrm{NO}$ for constant temperature processes on a large time scale 


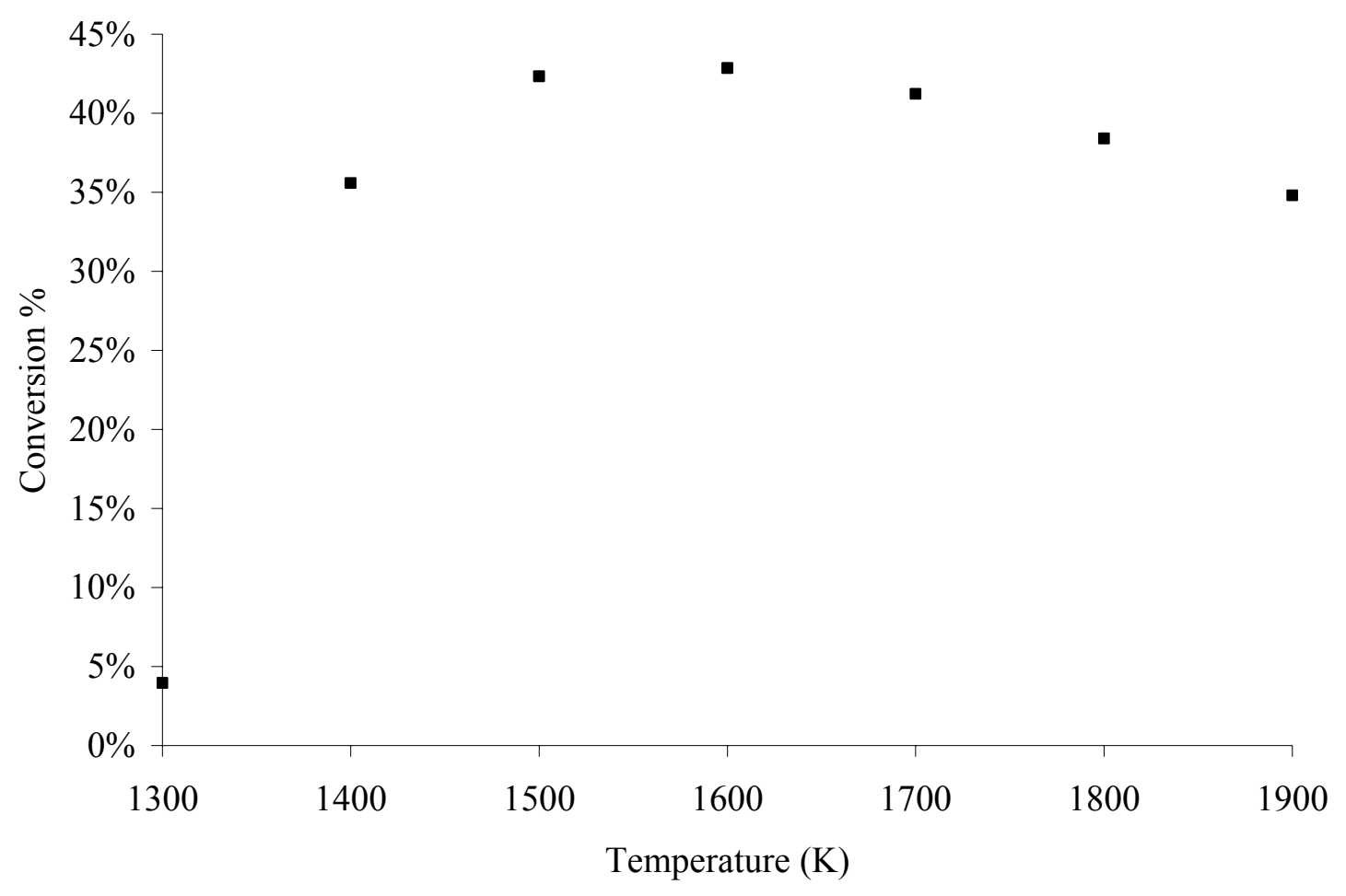

Figure 22: Conversion percentage at various temperatures

Figure 22 is a representation of NO conversion rates for varying combustion temperatures. These values represent the amount of $\mathrm{NO}_{\mathrm{X}}$ converted after 4 milliseconds, as seen by the vertical dashed line in Figure 22 .

\subsubsection{PERCENT $\mathrm{CH}_{4} \mathrm{METHOD}$}

This method of calculating the $\mathrm{NO}_{\mathrm{X}}$ conversion efficiency assumes that when $98 \%$ of the $\mathrm{CH}_{4}$ has been consumed, the reactions freeze, and $\mathrm{NO}_{\mathrm{X}}$ is no longer being converted. Another method that may have been used would be to assume different percentage conversion for each temperature. This value of $98 \%$ was chosen because it is representative of the time at which the $\mathrm{CH}_{4}$ reaction rates slowed to rates that were 
considered negligible as seen in Figure 23. This assumption was necessary because $100 \%$ combustion is not reached within CHEMKIN's solver, reaction rates are just slowed to near zero levels, and $\mathrm{CH}_{4}$ levels are reduced to $10^{-10}$ mole fraction or less. $99 \%$ and $97 \%$ $\mathrm{CH}_{4}$ burn percentages were also tested, with variations in the conversion percentage of less than $5 \%$. Another method that may have been used would be to assume different percentage conversion for each temperature. This would then require knowledge of in cylinder temperature distributions that is beyond the scope of this work. A simple logic statement was written to find the time at which $98 \%$ of the initial quantity of $\mathrm{CH}_{4}$ was consumed, for the lean case this corresponds to $98 \%$ of 0.07 mole fraction, or 0.0014 mole fraction of $\mathrm{CH}_{4}$. The time frame for this percentage of $\mathrm{CH}_{4}$ to be consumed varies with temperature, as can be seen in Figures 23, 25, 27, and 29 for the varying mixtures of gases. This time was then used to find the mole fraction of $\mathrm{NO}_{\mathrm{X}}$, shown in Figures 24, 26, 28 , and 30 , in the mixture at that time, which then gave the $\mathrm{NO}_{\mathrm{X}}$ conversion.

The percent $\mathrm{CH}_{4}$ method was chosen when evaluating EGR and stoichiometric characteristics. Since the in cylinder pressure is not yet measured, the time frame in which reactions are actually occurring is not yet known. This does not discredit the line method, but just means that more information is needed to make it a useful tool. In actuality a composite of the two methods may predict the $\mathrm{NO}_{\mathrm{X}}$ conversion efficiencies more accurately than either method alone. 


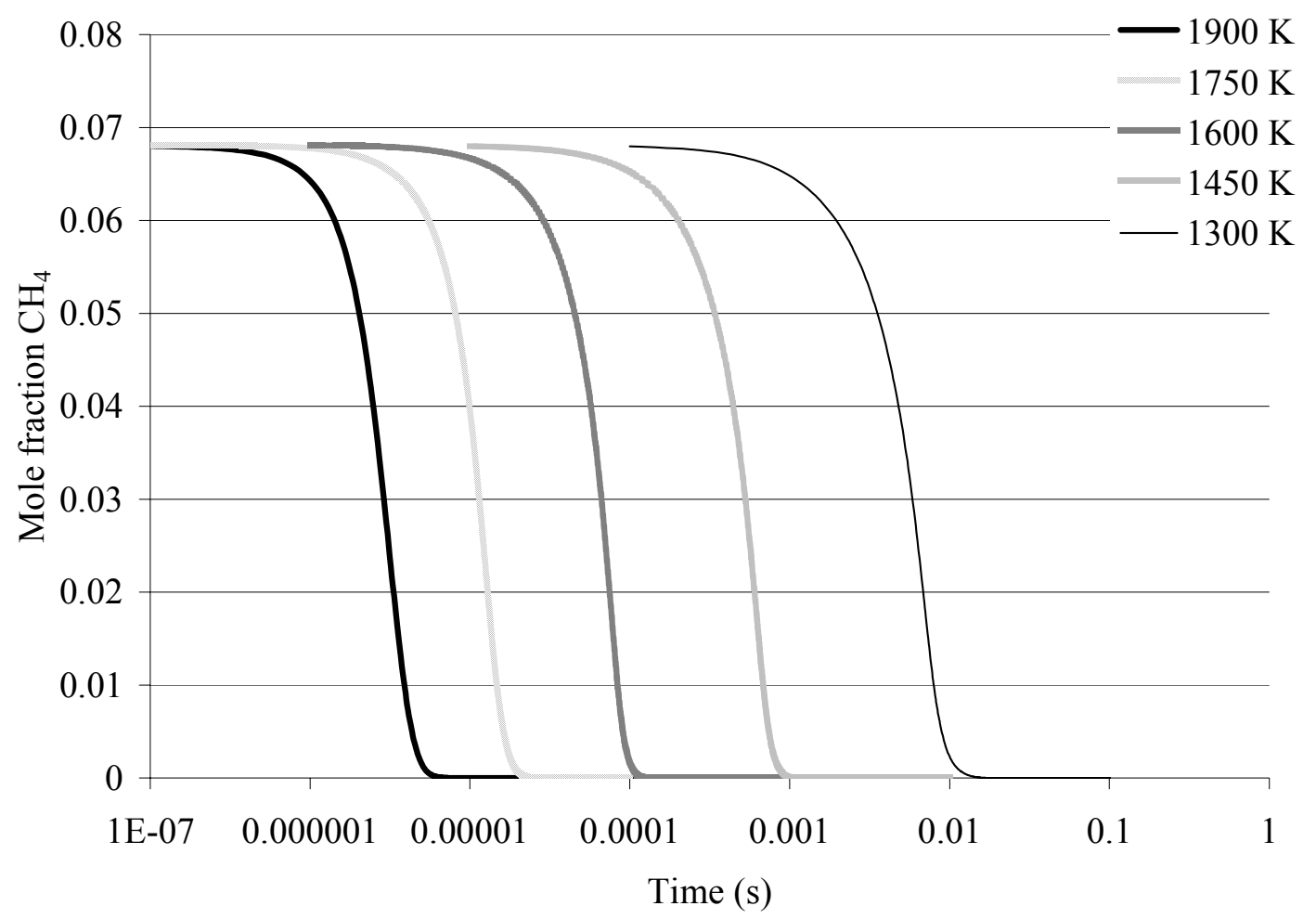

Figure 23: Mass depletion of $\mathrm{CH}_{4}$ for a lean ( $\lambda$ equals 1.4) mixture, with $25,000 \mathrm{ppm} \mathrm{NO}$ 


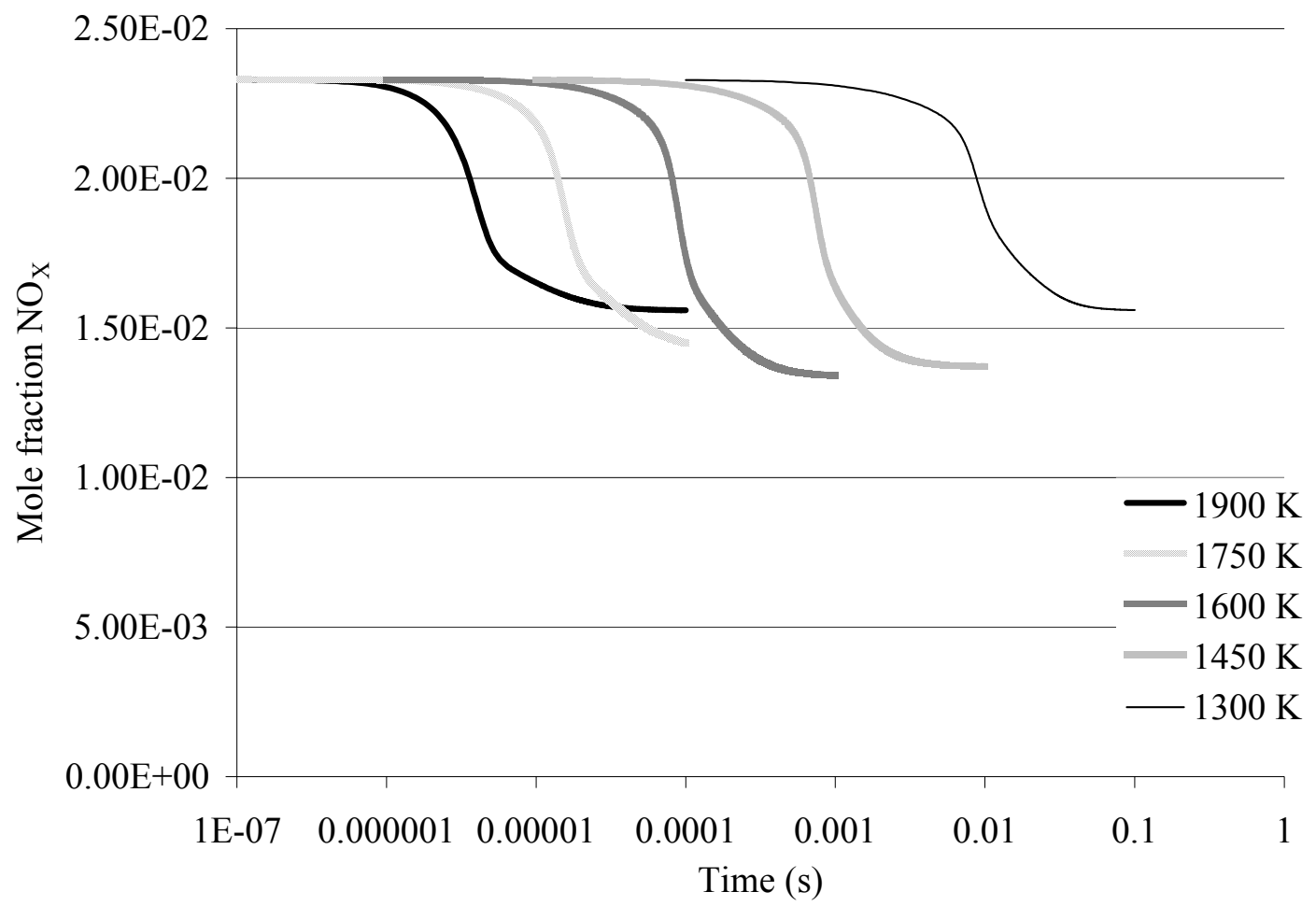

Figure 24: Mass conversion of $\mathrm{NO}_{\mathrm{X}}$ for a lean ( $\lambda$ equals 1.4) mixture, with 25,000 ppm NO

\subsection{STOICHIOMETRIC CASE}

Stoichiometric burn represented in Figure 25 and Figure 26 occurs at much higher flame temperatures than the lean burn case. Just as higher temperatures cause higher baseline $\mathrm{NO}_{\mathrm{X}}$ values from increased reaction rates, the reverse rates of reaction when elevated concentrations of NO are present in the intake air are also increased, leading to higher NO conversion than for the lean case. 


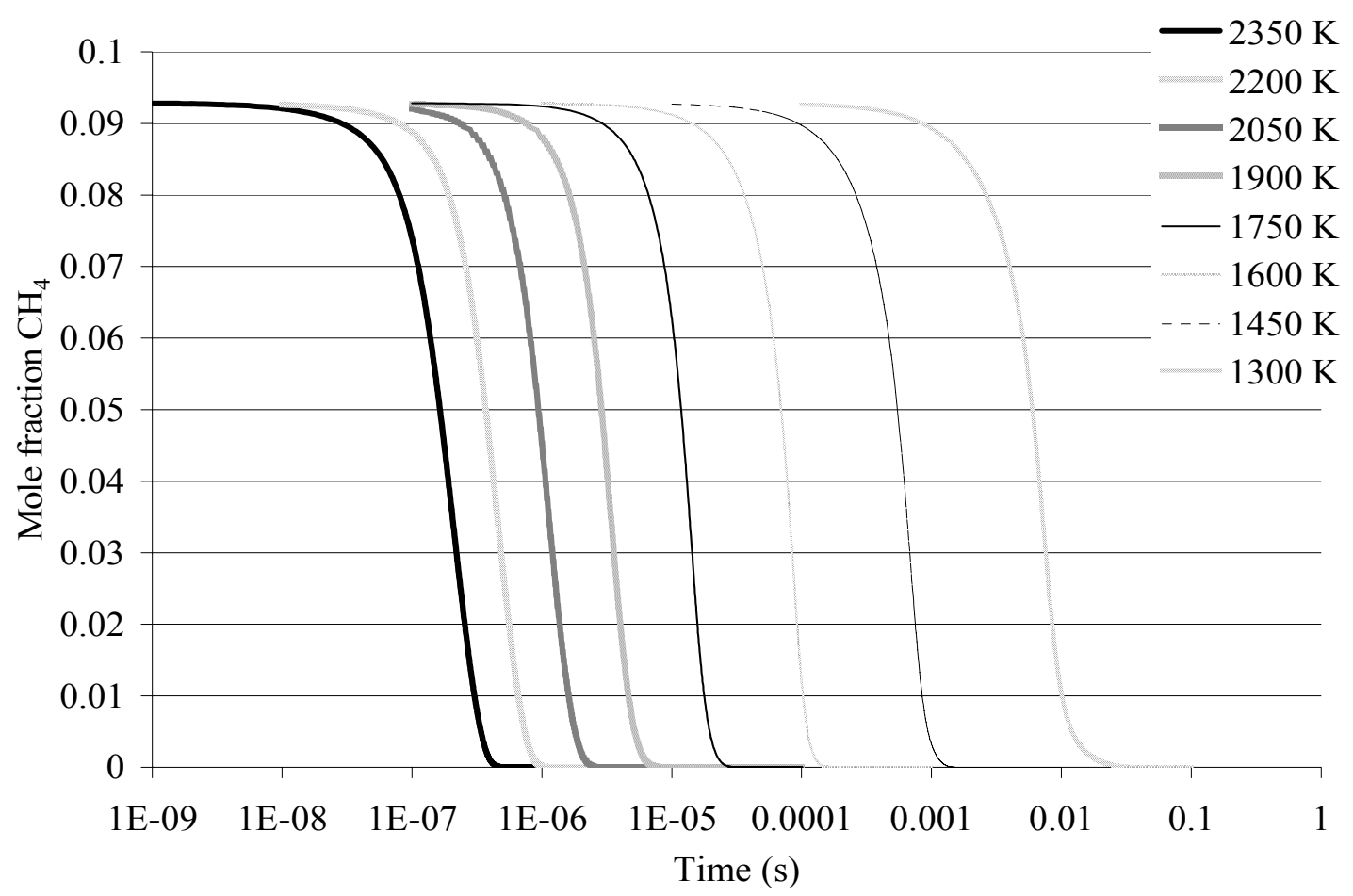

Figure 25: Mass depletion of $\mathrm{CH}_{4}$ for the stoichiometric ( $\lambda$ equals 1) mixture, with 25,000 ppm NO 


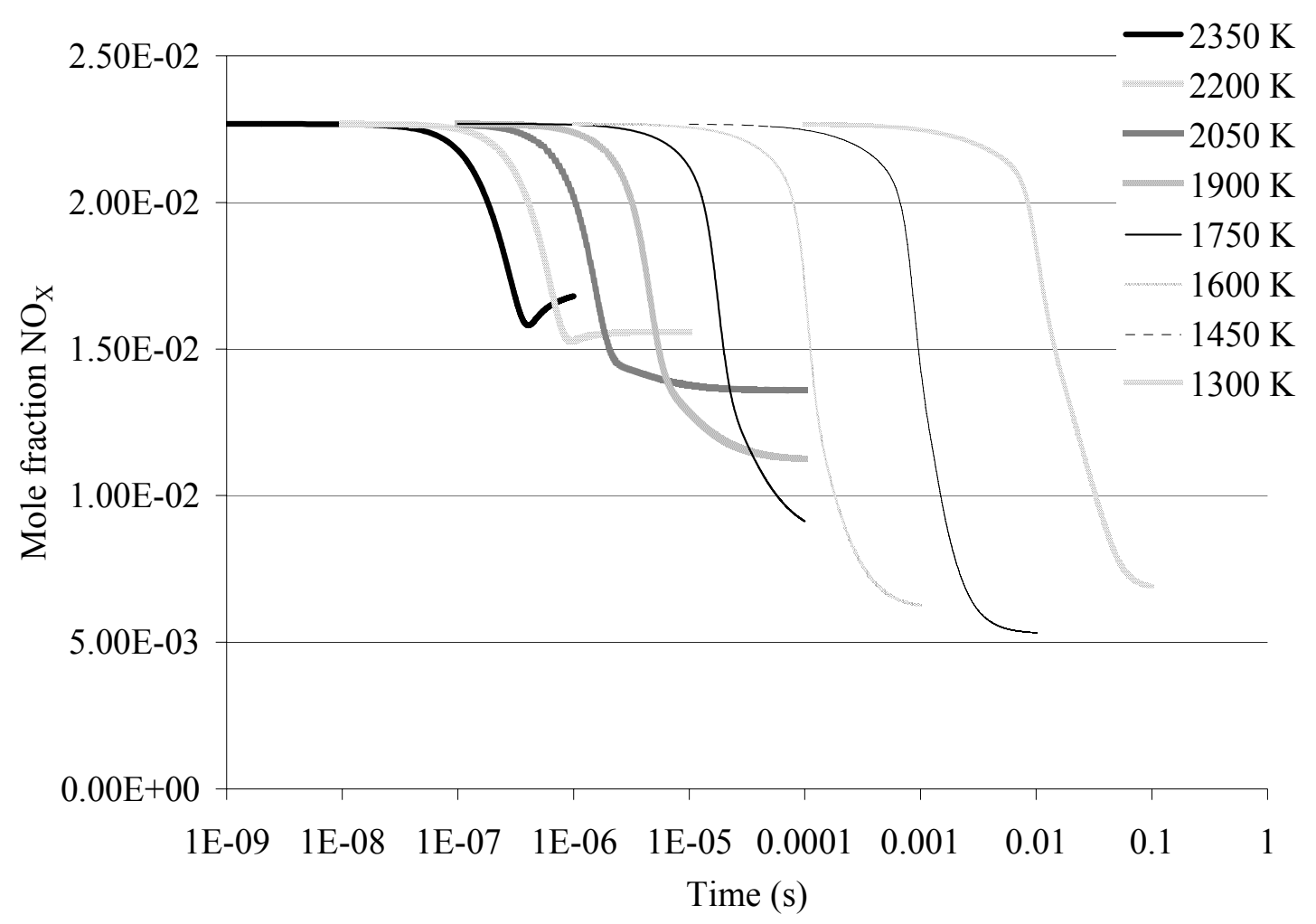

Figure 26: Mass conversion of $\mathrm{NO}_{\mathrm{X}}$ for the stoichiometric ( $\lambda$ equals 1 ) mixture, with

$$
\text { 25,000 ppm NO }
$$

\subsection{EGR CASE}

With an exhaust gas mixture in the intake air, the conversion rates have increased from those of the lean case. Even at the same combustion temperatures as the lean case the reaction rates are significantly higher. This leads to the conclusion that the added intake species $\mathrm{CO}, \mathrm{CO}_{2}$, and $\mathrm{H}_{2} \mathrm{O}$ are causing an increased rate of reaction and depletion of NO. 


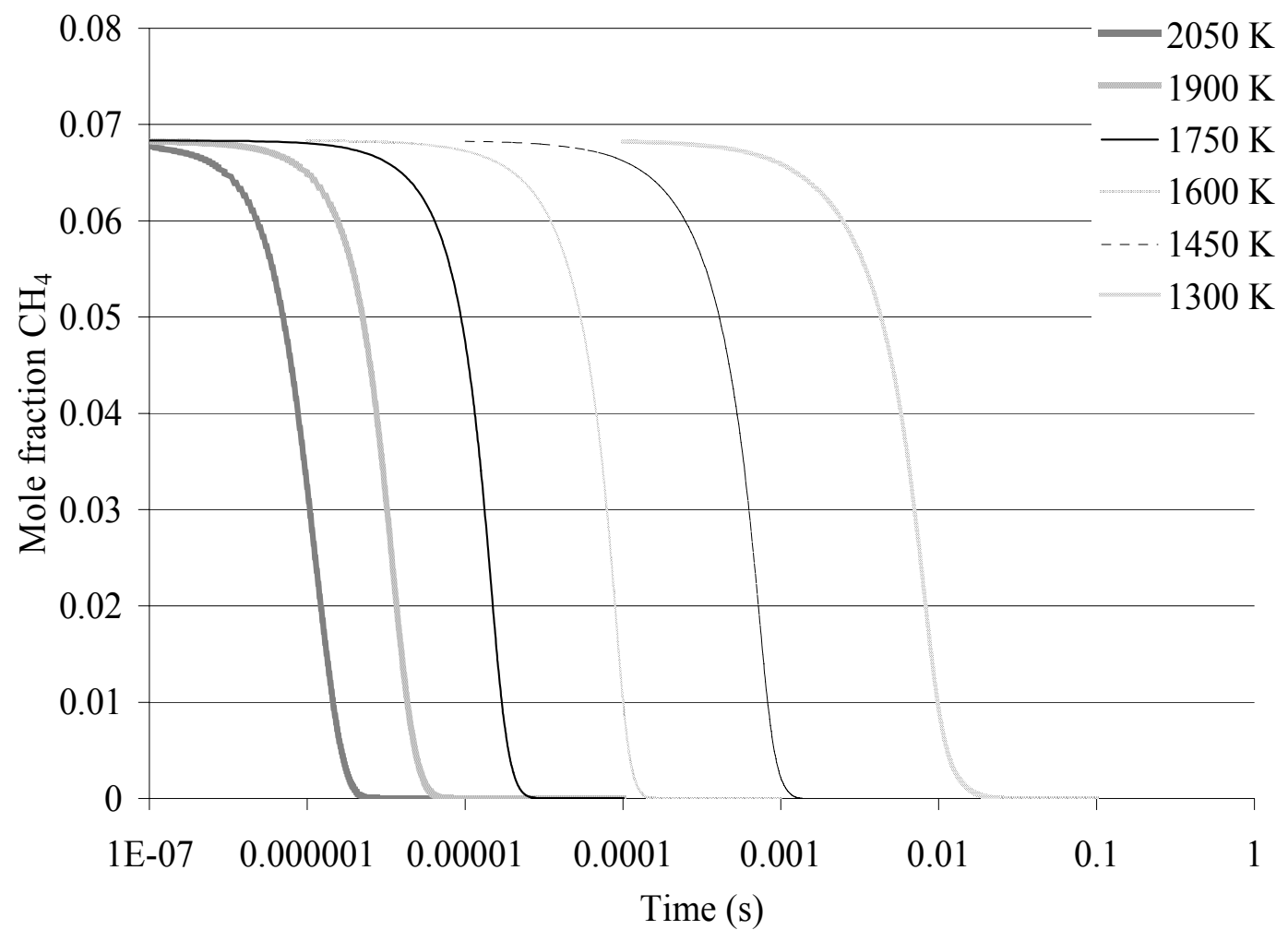

Figure 27: Mass depletion of $\mathrm{CH}_{4}$ for a lean ( $\lambda$ equals 1.4) mixture, with $20 \%$ EGR and $25,000 \mathrm{ppm} \mathrm{NO}$ and 


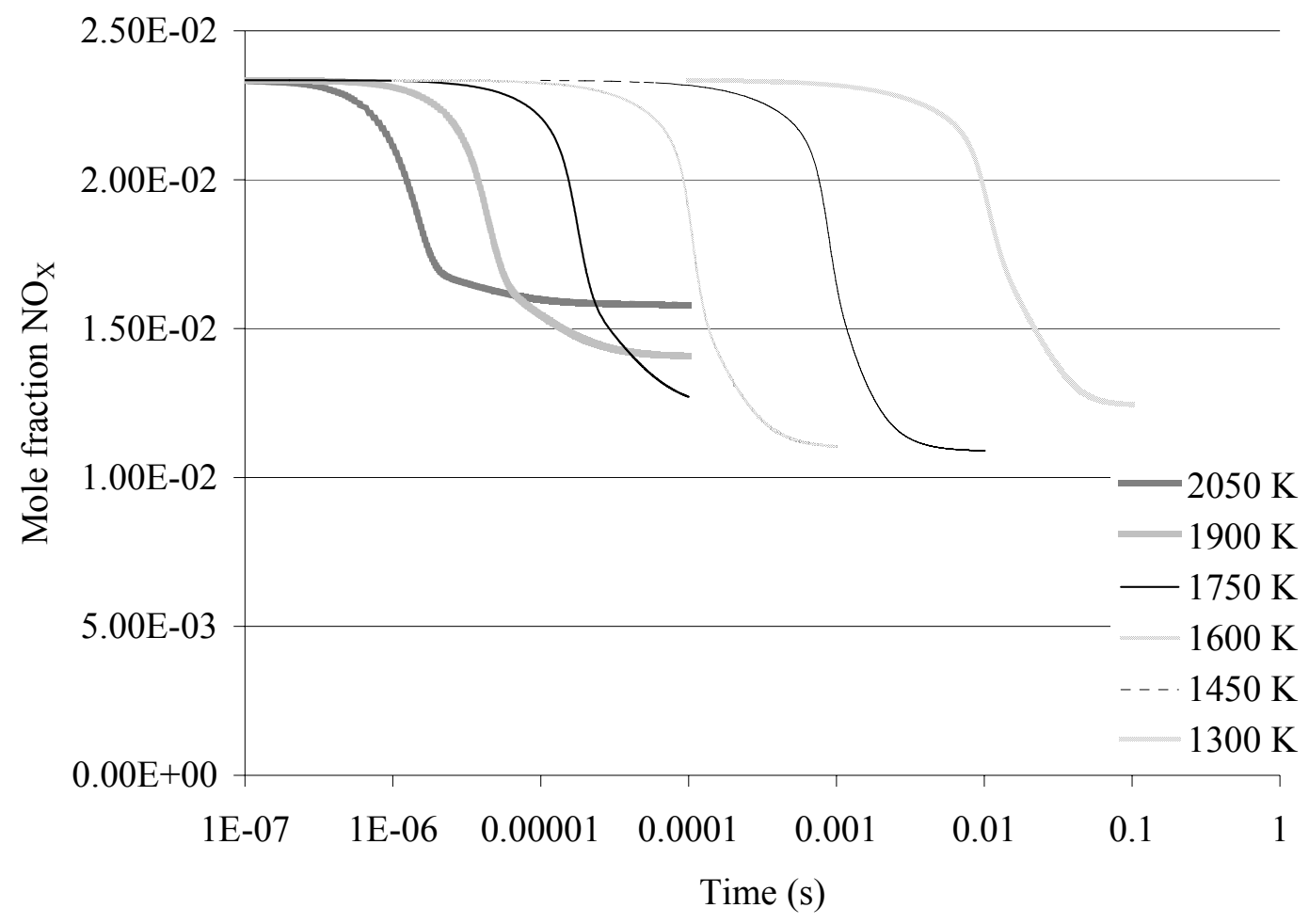

Figure 28: Mass conversion of $\mathrm{NO}_{\mathrm{X}}$ for a lean ( $\lambda$ equals 1.4) mixture, with $20 \%$ EGR and $25,000 \mathrm{ppm} \mathrm{NO}$ and

\subsection{RICH BURN CASE}

The rich burn case exhibits the highest overall modeled conversion efficiencies. Conversion efficiencies ranging from 35 to $50 \%$ are shown here using the $\mathrm{CH}_{4}$ method. This rich burn model shows that heightened levels of $\mathrm{CH}_{4}$ in the intake air give the largest overall reduction in NO. This also leads the author to believe that by increasing the dwell time of the gasses in the engine cylinder, and allowing lower combustion temperatures will yield conversion rates exceeding $90 \%$. This is demonstrated by the vertical dashed line in Figure 30, which shows that at combustion temperatures of $1450 \mathrm{~K}$ $90 \%$ conversion will be achieved if the gasses are kept at these elevated temperature 
(increased dwell time). The vertical dashed line is drawn at $4 \mathrm{~ms}$, which corresponds to the time it takes the piston to go from $10^{\circ}$ before to $10^{\circ}$ after TDC at $800 \mathrm{RPM}$.

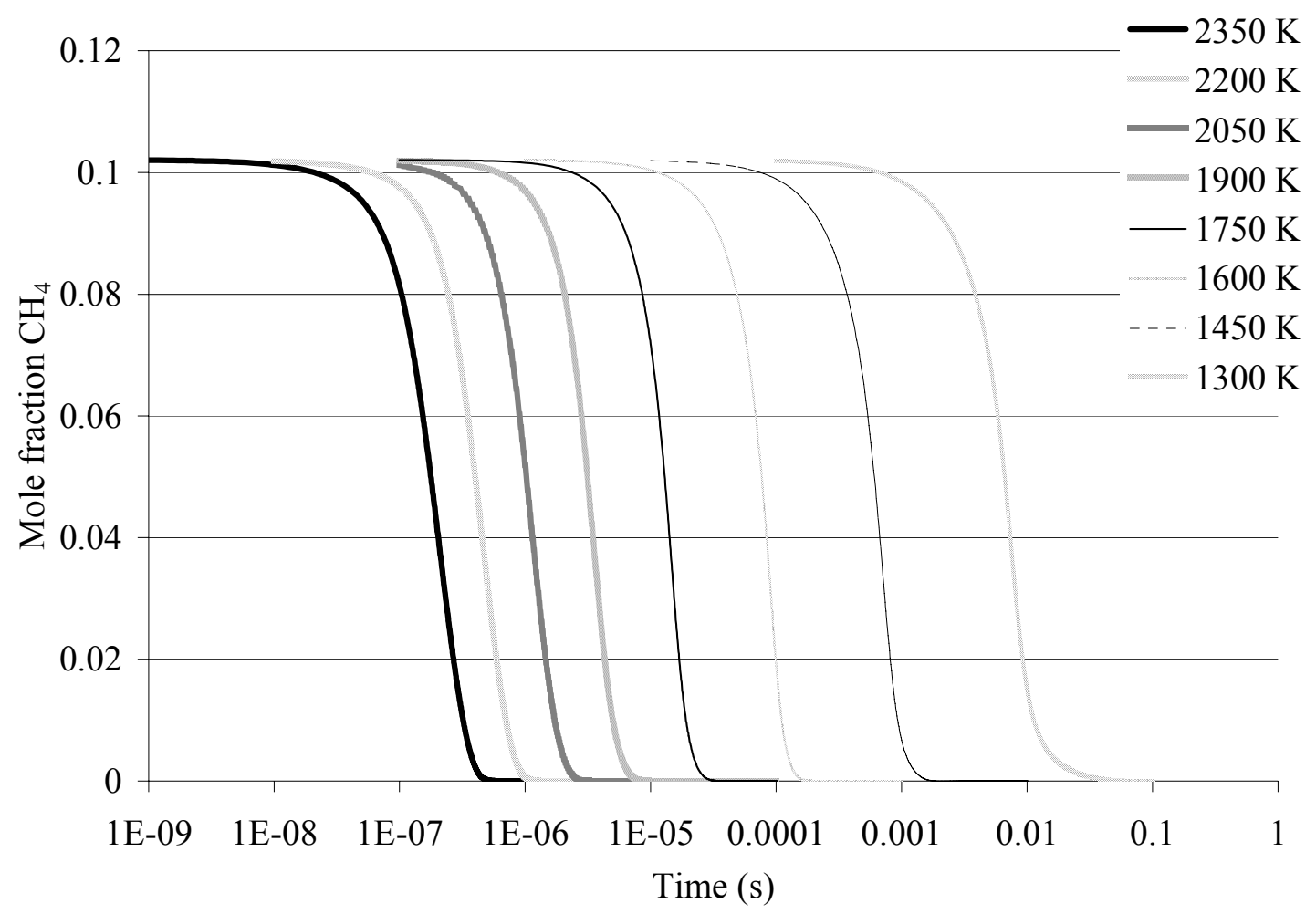

Figure 29: Mass depletion of $\mathrm{CH}_{4}$ for the rich ( $\lambda$ equals .9) mixture with 25,000 ppm NO 


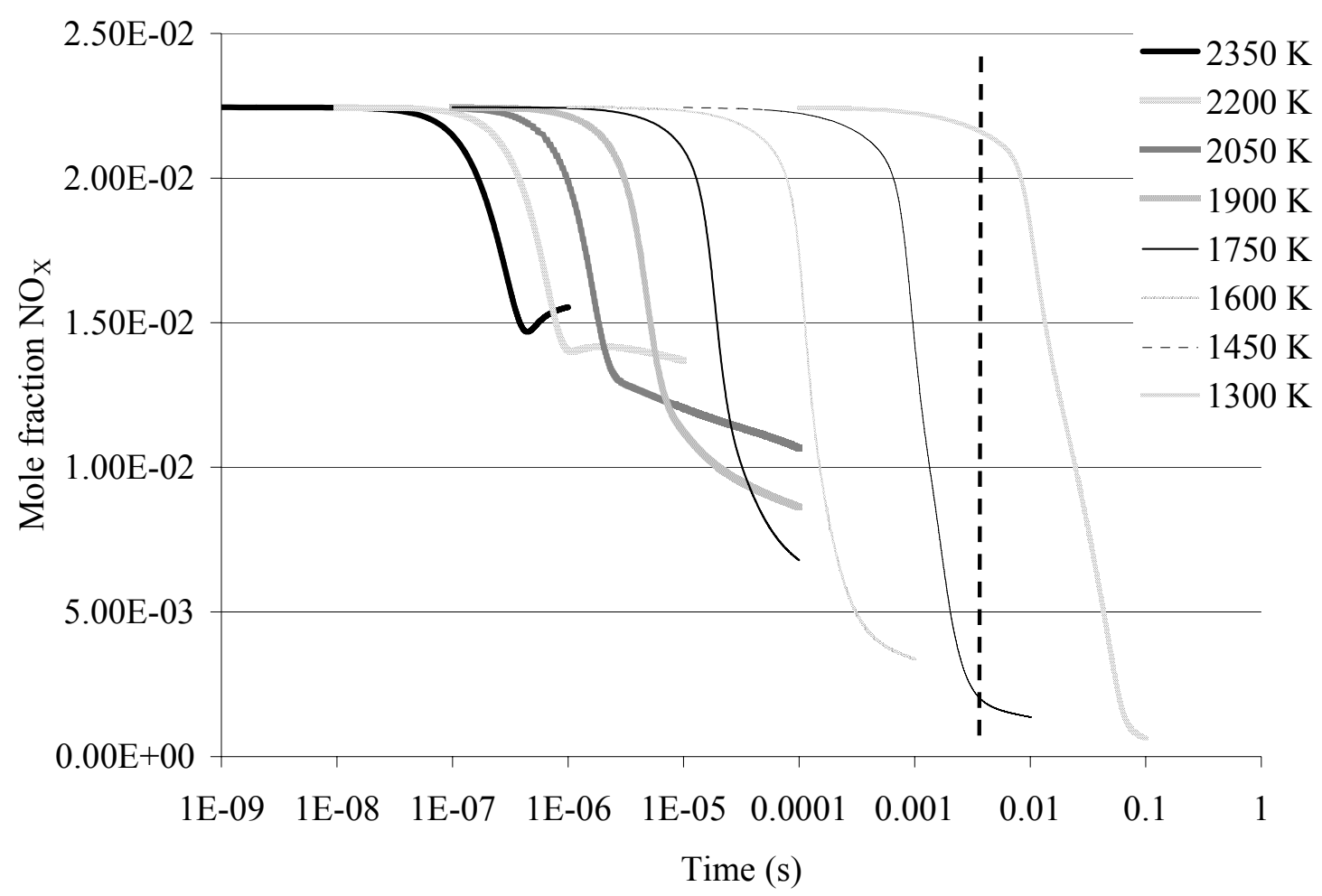

Figure 30: Mass conversion of $\mathrm{NO}_{\mathrm{X}}$ for a rich ( $\lambda$ equals .9 ) mixture with $25,000 \mathrm{ppm} \mathrm{NO}$

\subsection{SUMMARY OF CHEMICAL KINETIC MODELING RESULTS}

The chemical kinetic modeling attempts to show that for a given initial mixture of gases in an engine cylinder, reacting at varying in cylinder temperatures, the NO conversion rate can be modeled by a single packet of gases reacting at varying temperatures, and the conversion rate of the gases in the cylinder should lie within the bounds of the conversion rates of the individual packets, as seen in Figure 31, which shows the NO conversion rates using the $\mathrm{CH}_{4}$ method of calculation. The upper bound for the combustion temperature range was set by the theoretical adiabatic flame temperature, and the lower bound of $1300 \mathrm{~K}$ was based on plots of $\mathrm{CH}_{4}$ and $\mathrm{NO}_{\mathrm{X}}$ for temperatures lower than 1300 $\mathrm{K}$. The plots of $\mathrm{NO}_{\mathrm{X}}$ versus time for each of the cases show that for $1300 \mathrm{~K}$ combustion 
temperatures, the reactions take on the order of .1 seconds to occur. This is much larger than the time in which reactions are actually occurring in the engine cylinder, so temperatures less than this value were neglected. Although $\mathrm{NO}_{\mathrm{X}}$ conversion may not have time to occur when considering the actual time scales for combustion when compared to the time scales for reaction at $1300 \mathrm{~K}$, the percentage of gases that are reacting at this temperature in the engine cylinder are relatively low, and the trend of increasing $\mathrm{NO}_{\mathrm{X}}$ conversion with added EGR and more fuel rich mixtures should still be valid. These modeling results lead to the conclusion that heightened combustion temperatures and excess $\mathrm{CH}_{4}$ associated with rich and stoichiometric burn increase NO conversion efficiencies. EGR components of $\mathrm{CO}, \mathrm{CO}_{2}$, and $\mathrm{H}_{2} \mathrm{O}$ also increase $\mathrm{NO}$ reaction rates and conversion efficiencies. These results also lead the author to believe that conversions up to $90 \%$ can be achieved with proper management air-fuel ratio as shown in Figure 30, which is similar to the results obtained for a gasoline engine operating under stoichiometric conditions [2]. 


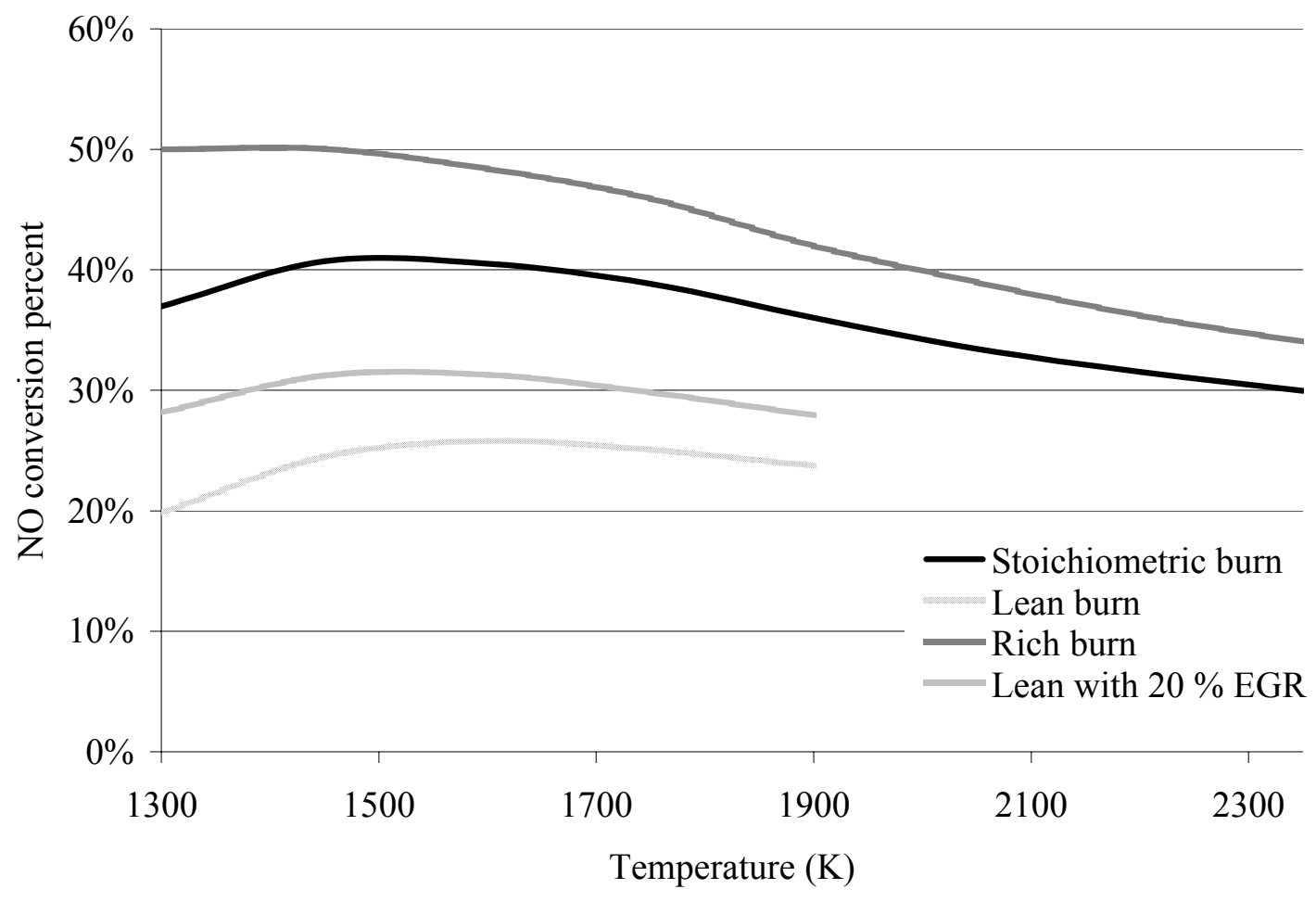

Figure 31: Summary of NO conversion percentages for all cases 


\section{OVERALL SNR EFFICIENCY}

\subsection{ADSORBER CHARACTERISTICS}

Sorbent Technologies Corporation of Twinsburgh, OH completed initial testing of the carbon based $\mathrm{NO}_{\mathrm{X}}$ adsorbent material [35]. Shown below in Figure 32 and Figure 33 are the results of this testing.

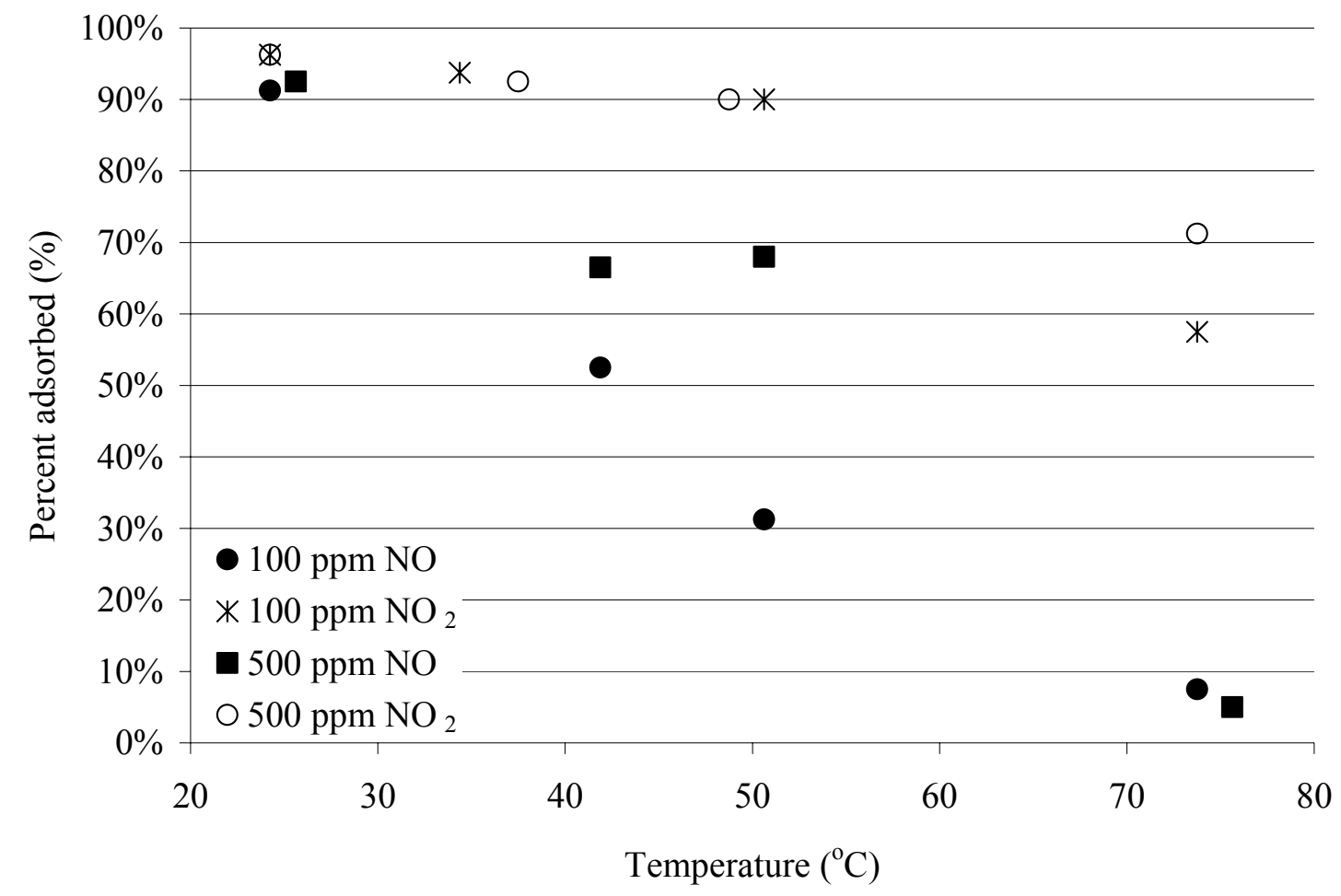

Figure 32: Adsorption efficiency as a function of the cooled exhaust gas temperature for varied concentrations of $\mathrm{NO}$ and $\mathrm{NO}_{2}$ averaged over 60 minutes [35]

Quantities of $\mathrm{NO}$ and $\mathrm{NO}_{2}$ mixed with air were fed through the adsorber at 100 and 500 ppm levels and varying inlet gas temperature. The objective of this experiment was to mimic typical large bore stationary engine exhaust $\mathrm{NO}$ and $\mathrm{NO}_{2}$ emissions, and test the adsorbers efficiency for removing $\mathrm{NO}_{\mathrm{X}}$ at these levels. Figure 32 shows that increasing 
$\mathrm{NO}$ and $\mathrm{NO}_{2}$ concentration only slightly increase adsorber efficiency, and that exhaust gas temperature plays a major role in adsorber efficiency.

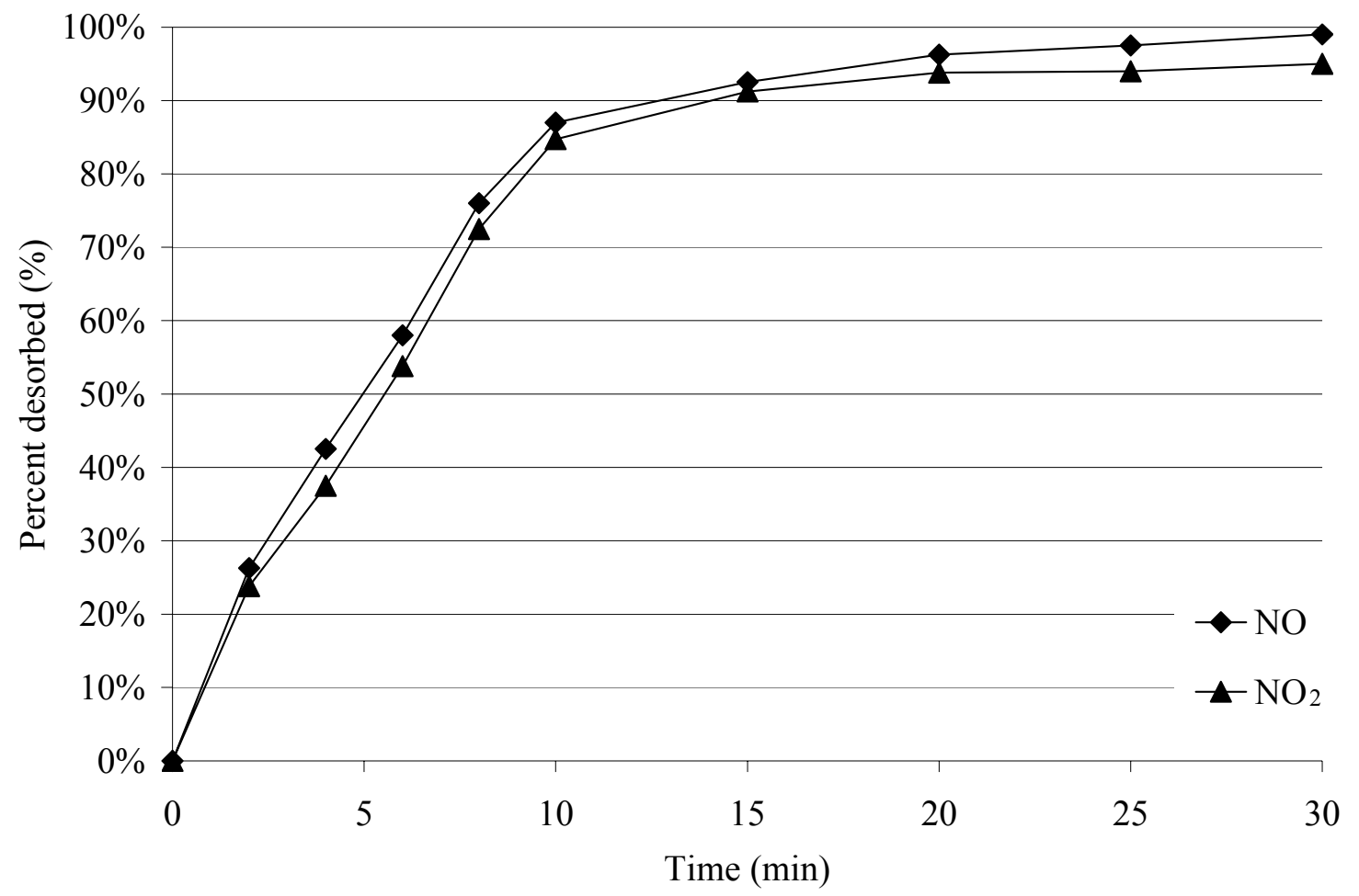

Figure 33: Desorption efficiency as a function of desorb time for $\mathrm{NO}$ and $\mathrm{NO}_{2}$ [35]

In the second set of tests, shown in Figure 33, the adsorber was first exposed to $1000 \mathrm{ppm}$ NO ladened air, in which the adsorber adsorbed 2.0 weight percent $\mathrm{NO}$ in the first cycle before the adsorption efficiency dropped below $85 \%$. The bed then desorbed $90 \%$ of the adsorbed gas when air heated to $300{ }^{\circ} \mathrm{C}$ was passed through the adsorber. Subsequent cycles showed the adsorber to adsorb 2.0 weight percent $\mathrm{NO}$ and desorb effectively all off it during the heated air adsorber regeneration. Secondly the effects of $\mathrm{NO} 2$ on the adsorption and desorption process were investigated [35]. 


\subsection{TWO ADSORBER SYSTEM EFFICIENCY}

To obtain an estimate of the maximum overall process conversion a two adsorber system was chosen. The advantage of this being that when one adsorber is in desortption mode, and passing concentrated $\mathrm{NO}_{\mathrm{X}}$ through the engine for conversion, the other adsorber will be adsorbing the concentrated $\mathrm{NO}_{\mathrm{X}}$ stream as it is leaving the engine. The baseline engine out $\mathrm{NO}_{\mathrm{X}}, \dot{m}_{\text {engine_out }}$, for this overall process conversion efficiency model was assumed to be $0.018 \mathrm{~g} / \mathrm{s}$ (value reported as $\mathrm{g} / \mathrm{s} \mathrm{NO}_{2}$ ), that of the Cummins L10G at the steady state engine operating point of $800 \mathrm{rpm}$ and $400 \mathrm{ft}-\mathrm{lb}$ load, Table 3 . At this operating condition the intake flow is 62 slps, Table 5. For a first approximation, the intake flow was assumed to be equal to the exhaust flow, which yielded a concentration of $144 \mathrm{ppm}$. The adsorber's adsorption efficiency, $\eta_{a}$, is approximately $90 \%$ for this concentration with the appropriate exhaust gas temperature. The $\mathrm{NO}_{\mathrm{X}}$ capacity of the adsorber, $m_{a}$, was assumed to be $0.2 \mathrm{~kg}$ of $\mathrm{NO}_{\mathrm{X}}$, and the desorption time, $t_{d}$, which is a function of the thermal transients of the adsorbent material and residence time of the exhaust gas in the adsorber, was assumed to be 10 minutes. The adsorber was modeled to completely desorb all of the adsorbed $\mathrm{NO}_{\mathrm{X}}$. In reality, the adsorber would have to be sized to hold slightly more $\mathrm{NO}_{\mathrm{X}}$ than this to account for residual $\mathrm{NO}_{\mathrm{X}}$ that was not desorbed. Finally, the engine conversion, $\eta_{\mathrm{c}}$, was assumed to be $50 \%$, which CHEMKIN modeling has shown can be reached with EGR and slightly rich operation.

Assuming the two adsorber system starts with the first adsorber full and desorbing into the second adsorber, the flow out of the first adsorber, $\dot{m}_{\text {adsorber_out }}$ would be: 


$$
\dot{m}_{\text {adsorber_out }}=m_{a} / t_{d}
$$

Equation 8

The engine then converts a percentage of this flow, and the amount of $\mathrm{NO}_{\mathrm{X}}$ going into the second adsorber, $\dot{m}_{\text {adsorber_inl }}$, is the adsorption efficiency, times the sum of the baseline engine out $\mathrm{NO}_{\mathrm{X}}$ plus this desorbed flow after conversion:

$$
\dot{m}_{\text {adsorber_in1 }}=\eta_{a}\left[\dot{m}_{\text {engine_out }}+\left(1-\eta_{c}\right)\left(\dot{m}_{\text {adsorber_out }}\right)\right]
$$

Equation 9

The adsorber also allows a percentage of the flow to pass through the adsorber during this time:

$$
\dot{m}_{\text {adsorber_out } 1}=\left(1-\eta_{a}\right)\left[\dot{m}_{\text {engine_out }}+\left(1-\eta_{c}\right)\left(\dot{m}_{\text {adsorber_out }}\right)\right]
$$

Equation 10

Once the first adsorber has completed desorption, the adsorber finishes adsorbing baseline engine out $\mathrm{NO}_{\mathrm{X}}, \dot{m}_{\text {engine_out }}$, until the adsorption capacity, $m_{a}$, is reached. The amount of $\mathrm{NO}_{\mathrm{X}}$ entering the adsorber during this time can be expressed as:

$$
\dot{m}_{\text {adsorber_in2 }}=\eta_{a} \cdot \dot{m}_{\text {engine_out }}
$$

Equation 11

The flow allowed to pass through the adsorber during this time can be expressed as:

$$
\dot{m}_{\text {adsorber_out } 2}=\left(1-\eta_{a}\right) \dot{m}_{\text {engine_out }}
$$


The total adsorption time, $t_{a}$, can then be expressed as the desorption time plus the remaining time to reach the adsorption capacity.

$$
t_{a}=t_{d}+\left[m_{a}-\dot{m}_{\text {adsorber_in1 }}\left(t_{d}\right)\right] / \dot{m}_{\text {engine_in } 2}
$$

Figure 34 shows the resulting $\mathrm{NO}_{\mathrm{X}}$ emissions after the two adsorber system has been applied. The dashed line represents the real time system out $\mathrm{NO}_{\mathrm{X}}$. This was then time averaged to investigate overall process conversion.

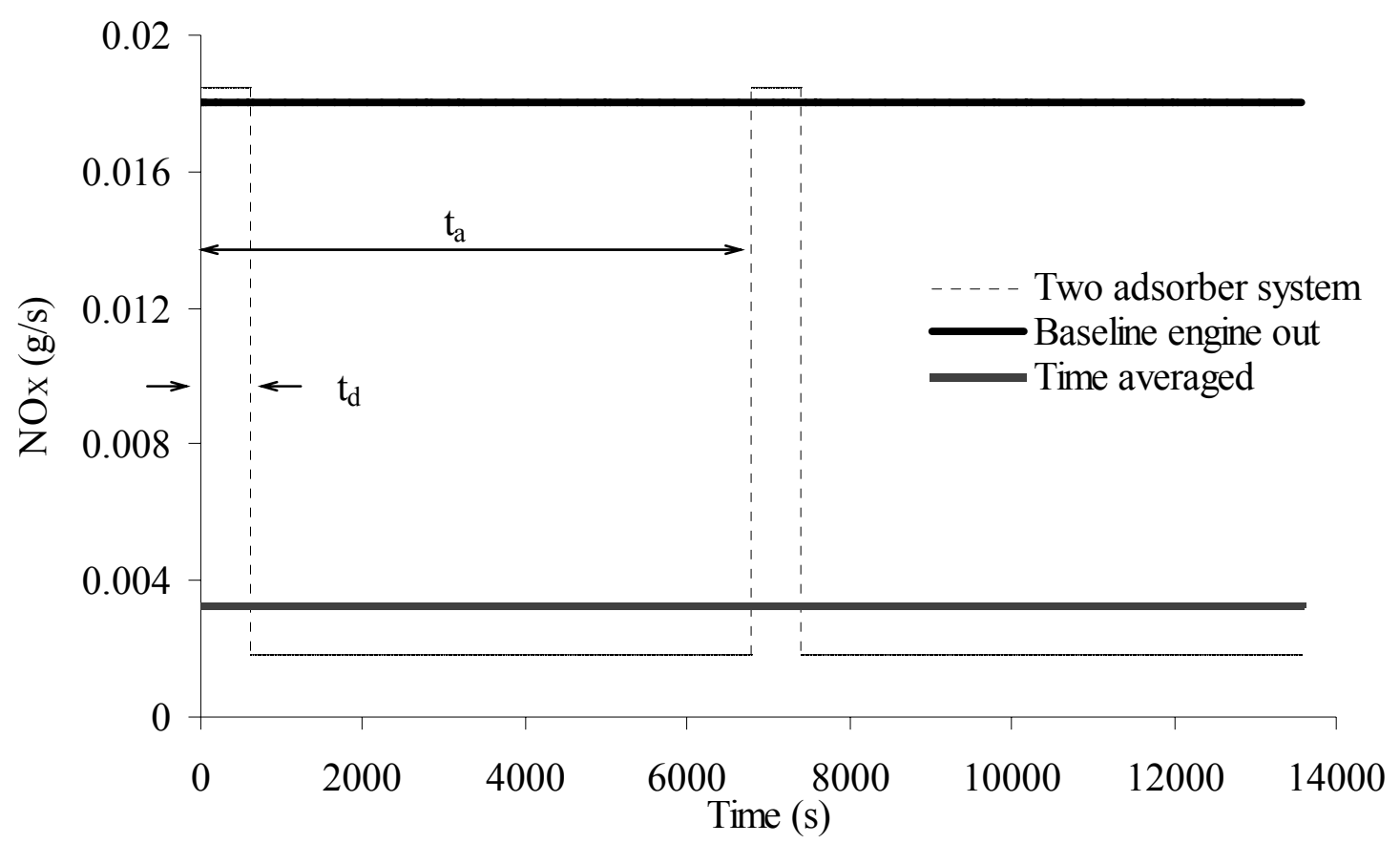

Figure 34: $\mathrm{NO}_{\mathrm{X}}$ emissions for the two adsorber model, with $0.018 \mathrm{~g} / \mathrm{s}$ engine out emissions without aftertreatment and 90\% adsorber efficiency 
The periodic spikes in the dashed line of Figure 34 represent the time periods in which concentrated desorbed gas is being passed through the engine for conversion. This process will be repeated until the adsorbent material is degraded to the point that it needs replaced. The time averaged line Figure 34 represents an average overall conversion of $82 \%$ for the two adsorber system. As the engine conversion efficiency approaches $100 \%$ overall conversion approaches the adsorber efficiency. If an adsorber efficiency of $90 \%$ could be achieved through close exhaust gas temperature control, and close $\mathrm{NO}_{\mathrm{X}}$ concentration control through adsorption and desorption timing, and engine conversion efficiencies of $90 \%$ were achieved through slightly rich operation, as the CHEMKIN modeling suggests may be possible, overall $\mathrm{NO}_{\mathrm{X}}$ conversions exceeding $90 \%$ could be achieved. 


\section{CONCLUSIONS}

In conclusion it is possible to convert NO into harmless gases by passing it through a spark ignited natural gas engine at sufficiently high concentrations and engine loads. It was found that the NO conversion rates varied only slightly as load increased, as seen in Figure 11. This behavior may be linked to that of Figure 22, which indicates at temperatures of $1400 \mathrm{~K}$ and above, the conversion rates varied only by $7 \%$ as compared to a variation of only $5 \%$ in Figure 11 . Although Figure 22 represents the conversion percentage in a packet of gases at particular temperatures, a continuum of packets with temperatures in the same range would also exhibit the same behavior, as in an engine cylinder. Conversion rate predictions from $35 \%$ to $42 \%$ were estimated using the line method and $20 \%$ to $26 \%$ using the $\mathrm{CH}_{4}$ method, and conversions of $18 \%$ to $23 \%$ were observed experimentally. The overestimate of NO conversion by using the line method comes from not knowing the actual time period in which reactions are occurring in the engine cylinder. The $\mathrm{CH}_{4}$ method predicts the range of values for $\mathrm{NO}_{\mathrm{X}}$ conversion that occurred in experiments within $\pm 3 \%$. Knowledge of in-cylinder pressure measure may prove to be a very useful tool in determining a better estimate for the time frame in which reactions are occurring. The NO conversion for slightly rich operation, shown in Figure 30 , of $90 \%$ may be achieved with close control of combustion temperatures and timing.

The data to the left of the vertical dashed line in Figure 20 represent the time frame in which NO conversions would actually occur in an internal combustion engine. Since the mixture has not yet reached equilibrium, the $\mathrm{NO}_{\mathrm{X}}$ conversion phenomenon can be labeled as a rate limited process, rather than equilibrium limited. This means that the NO 
conversion rate is a function of the reaction rates for the various reactions leading to $\mathrm{NO}_{\mathrm{X}}$ production. This also gives insight into why Figure 10 only showed modest increases in the NO conversion rate as the initial concentration of NO was increased.

It was observed that the air-fuel ratio had little effect on $\mathrm{CO}_{2}$ and a modest effect on $\mathrm{CO}$ and $\mathrm{HC}$ baseline emissions during actual engine testing, but it had a substantial effect on $\mathrm{NO}_{\mathrm{X}}$. This effect is widely acknowledged [36]. CHEMKIN showed similar trends when reaction rates with varying air-fuel ratios were compared, and showed that increasing $\lambda$ lead to increased reaction rates of NO, leading to increased conversion rates. Addition of EGR also showed increased NO reaction and conversion rates. The variations in air fuel ratio may have effected some of the conversion percentage trends that were shown in the experimental data, but even at the set points where constant air-fuel ratio was achieved, $\mathrm{NO}_{\mathrm{X}}$ conversion remained relatively constant for varying injection quantities and loads.

With proper control of a two adsorber system and management of air-fuel ratio and EGR $90 \%$ overall $\mathrm{NO}_{\mathrm{X}}$ conversion efficiencies should be achieved with the SNR process. If a normally lean burn natural gas engine is operated under stoichiometric or slightly rich conditions with EGR for short periods of time, long enough to convert the desorbed NO, $90 \%$ engine conversion should be achieved. 


\section{REFERENCES}

[1]. R. W. Weeks and J. J. Moskwa, "Transient Air Flow Rate Estimation in a Natural Gas Engine Using a Nonlinear Observer," SAE 940759, Society of Automotive Engineers, Warrendale, PA 1994.

[2]. B. Krutzsch, G. Wenninger, M. Weibel, P. Stapf, A. Funk, D. E. Webster, E. Chaize, B. Kasemo, J. Martens, and A. Kiennemann, "Reduction of $\mathrm{NO}_{\mathrm{X}}$ in Lean Exhaust by Selective $\mathrm{NO}_{\mathrm{X}}-$ Recirculation (SNR -Technique), Part II: $\mathrm{NO}_{\mathrm{X}}$ Storage Materials," SAE 982592, Society of Automotive Engineers, Warrendale, PA 1998.

[3]. E. Chaize, D. E. Webster, B. Krutzsch, G. Wenninger, M. Weibel, S. Hodjati, C. Petit, V. Pitchon, A. Kiennemann, R. Loenders, O. Monticelli, P. A. Jacobs, J. Martens, and B. Kasemo, "Reduction of $\mathrm{NO}_{\mathrm{X}}$ in Lean Exhaust by Selective $\mathrm{NO}_{\mathrm{X}}$ - Recirculation (SNR -Technique), Part I: System and Conversion Process," SAE 982592, Society of Automotive Engineers, Warrendale, PA 1998.

[4]. R. J. Kee, F. M. Rupley, J. A. Miller, M. E. Coltrin, J. F. Grcar, E. Meeks, H. K. Moffat, A. E. Lutz, G. Dixon Lewis, M. D. Smooke, J. Warnatz, G. H. Evans, R. S. Larson, R. E. Mitchell, L. R. Petzold, W. C. Reynolds, M. Caracotsios, W. E. Stewart, P. Glarborg, C. Wang, O. Adigun, W. G. Houf, C. P. Chou, S. F. Miller, P. Ho, and D. J. Young, CHEMKIN Release 4.0, Reaction Design, Inc., San Diego, CA 2004.

[5]. S. Rousseau, B. Lemoult, and M. Tazerout, "Combustion Characterization of Natural Gas in a Lean Burn Spark-Ignition Engine," Proceedings of the Institution of Mechanical Engineers Part D-Journal of Automobile Engineering 213(D5):481-489, Département Systèmes Energétiques et Environment, Ecole des Mines de Nantes, France 1999.

[6]. S. C. Kong and R. D. Reitz, "Application of Detailed Chemistry and CFD for Predicting Direct Injection HCCI Engine Combustion and Emissions," Proceedings of the Combustion Institute 29:663-669, Chicago, IL 2003.

[7]. S. C. Kong and R. D. Reitz, "Use of Detailed Chemical Kinetics to Study HCCI Engine Combustion with Consideration of Turbulent Mixing Effects," Journal of Engineering for Gas Turbines and Power-Transactions of the ASME 124(3):702707, American Society of Mechanical Engineers, New York, NY 2002.

[8]. G. Smith, D. Golden, M. Frenklach, N. Moriarty, B. Eiteneer, M. Goldenberg, C. Bowman, R. Hanson, S. Song, W. Gardiner, V. Lissianski, and Z. Qin, http:// www.me.berkeley.edu/gri_mech, Berkely, CA 2004. 
[9]. K. S. Varde, J. C. Cherng, C. J. Bailey, and W. A. Majewski, "Emissions and Their Control in Natural Gas Fueled Engines," SAE 922250, Society of Automotive Engineers, Warrendale, PA 1992.

[10]. A. Manivannan, P. Tamil porai, S. Chandrasekaran, and R. Ramprabhu, "Lean Burn Natural Gas Spark Ignition Engine - An Overview," SAE 2003-01-0638, Society of Automotive Engineers, Warrendale, PA 2003.

[11]. S. Bhargarva, N. N. Clark, and M. W. Hildebrand, "Exhaust Gas Recirculation in a Lean-Burn Natural Gas Engine," SAE 922250, Society of Automotive Engineers, Warrendale, PA 1992.

[12]. T. Sakonji and F. Shoji, "Study on Improvement of Natural Gas Fueled Spark Ignition Engines -Effect of EGR Utilization," SAE 971714, Society of Automotive Engineers, Warrendale, PA 1997.

[13]. R. R. Raine, G. Zhang, and A. Pflug, "Comparison of Emissions from Natural Gas and Gasoline Fuelled Engines - Total Hydrocarbon and Methane Emissions and Exhaust Gas Recirculation Effects," SAE 970743, Society of Automotive Engineers, Warrendale, PA 1997.

[14]. K. B. Looney, "EGR as an Emission Reduction Strategy in a Spark-Ignited Natural Gas Engine," M. S. Thesis, West Virginia University, Morgantown, WV 1995.

[15]. C. Nellen and K. Boulouchos, "Natural Gas Engines for Cogeneration: Highest Efficiency and Near-Zero-Emissions through Tubocharging, EGR and 3-Way Catalytic Converter," SAE 2000-01-2825, Society of Automotive Engineers, Warrendale, PA 2000.

[16]. G. R. Neame, D. P. Gardiner, R. W. Mallory, V. K. Rao, M. F. Bardon, and V. Battista, "Improving the Fuel Economy of Stoichiometrically Fuelled S.I. Engines by menas of EGR and Enhanced Ignition - A Comparison of Gasoline, Methanol and Natural Gas," SAE 952376, Society of Automotive Engineers, Warrendale, PA 1995.

[17]. B. West, S. Huff, J. Parks, S. Lewis, J. Choi, W. Partridge, and J. Storey, "Assessing Reductant Chemistry During In-Cylinder Regeneration of Diesel Lean $\mathrm{NO}_{\mathrm{X}}$ Traps," SAE 2004-01-3023, Society of Automotive Engineers, Warrendale, PA 2004.

[18]. O. H. Bailey, "NOx Adsorbers for Diesel Applications: General Considerations and Operational Issues," DieselNet Technical Report, Ecopoint, Inc., Brampton, ON, Canada 1997.

[19]. W. A. Majewski, "Lean $\mathrm{NO}_{\mathrm{X}}$ Catalyst," DieselNet Technical Report, Revision 2004.01, Ecopoint, Inc., Brampton, ON, Canada 2004. 
[20]. W. A. Majewski, "NO $\mathrm{X}_{\mathrm{X}}$ Adsorbers," DieselNet Technical Report, Revision 2004.01, Ecopoint, Inc., Brampton, ON, Canada 2002.

[21]. T. Kobayashi, T. Yamada, and K. Kayano, "Study of $\mathrm{NO}_{\mathrm{X}}$ Trap Reaction by Thermodynamic Calculation," SAE 970745, Society of Automotive Engineers, Warrendale, PA 1997.

[22]. R. M. Heck and R. J. Farrauto, "Catalytic Air Pollution Control: Commercial Technology," Van Nostrand Reinhold, New York, NY 1995.

[23]. W. A. Majewski, "Selective Catalytic Reduction," DieselNet Technical Report, Revision 2003.11, Ecopoint, Inc., Brampton, ON, Canada 2003.

[24]. J. J. Yeh, H. Pennline, and C. Drummond, "New Strategy to Decompose Nitrogen Oxides from Regenerable Flue Gas Cleanup Processes," $194^{\text {th }}$ ACS National Metting, American Chemical Society, New Orleans, LA 1987.

[25]. "Enhancing the Use of Coals by Gas Reburning," Final Report, U.S. Department of Energy, Office of Fossil Energy, Federal Energy Technology Center, Morgantown, WV 1998.

[26]. R. Vellaisamy, N. N. Clark, G. J. Thompson, R. J. Atkinson, C. A. Tissera, and M. M. Swartz, "Assesment of $\mathrm{NO}_{\mathrm{X}}$ Destruction in Diesel Engines by Injecting NO in the Intake Manifold," SAE 2005-01-0379, Society of Automotive Engineers, Warrendale, PA 2005.

[27]. R. Vellaisamy, “Assesment of $\mathrm{NO}_{\mathrm{X}}$ Destruction in Diesel Engines by Injecting NO in the Intake," M. S. Thesis, West Virginia University, Morgantown, WV 1997.

[28]. C. A. Tissera, M. M. Swartz, E. Tatli, R. Vellaisamy, N. N. Clark, G. J. Thompson, R. D. Nine, and R. J. Atkinson, "Selective $\mathrm{NO}_{\mathrm{X}}$ Recirculation for Stationary Lean-Burn Natural Gas Engines," ICEF2004-839, ASME Fall 2004 Technical Conference, American Society of Mechanical Engineers, New York, NY 2004.

[29]. J. A. Hoppie, "Defining Drivetrain Losses in Developing a Cycle for Engine and Chassis Dynamometer Test Compliance and Uncertainty Analysis of Emissions Test Facilities,” M. S. Thesis, West Virginia University, Morgantown, WV 1997.

[30]. Code of Federal Regulations, Title 40, Part 86, "Emission Regulations for New Otto-Cycle and Diesel Heavy-Duty Engines; Gaseous and Particulate Exhaust Test Procedures," Washington, D.C. 1998.

[31]. W. S. Wayne, "A Paremetric Study of Knock Control Strategies for a Bi-Fuel Engine," Dissertation, West Virginia University, Morgantown, WV 1997. 
[32]. J. Cowart, M. Haghgooie, C. Newman, G. Davis, W. Pitz, and C. Westbrook, "The Intensity of Knock in an Internal Combustion Engine: An Experimental and Modeling Study," SAE 922327, Society of Automotive Engineers, Warrendale, PA 1992.

[33]. L. Dodge, J. Kubesh, D. Naegeli, and P. Campbell, "Modeling $\mathrm{NO}_{\mathrm{X}}$ Emissions from Lean-Burn Natural Gas Engines," SAE 981389, Society of Automotive Engineers, Warrendale, PA 1998.

[34]. M. W. Chase and D. R. Lide, "JANAF Thermochemical Tables," Journal of Physical and Chemical Reference Data, American Chemical Society, Washington, D.C. 1986.

[35]. B. W. Nelson, "Demonstration of a New Emission Control System for Stationary Diesel and Natural Gas Fired Engines," Final Report, California Air Resources Board, Sorbent Technologies Corporation, Twinsburgh, OH 2004.

[36]. J. Heywood, "Internal Combustion Engine Fundamentals," McGraw Hill, New York, NY 1988. 


\section{APPENDIX A: GRIMECH VERSION 3.0 CHEMKIN INPUT FILE}

The following description of the GRImech input file, used as the chemical kinetics input file that describes methane combustion, was taken from the CHEMKIN user manuals [4]. "First, the file specifies the elements and species that appear in the mechanism, and then includes the reaction mechanism description. The input is essentially format free. The elements and species names need only be separated by blank spaces. The character string that describes the reaction appears on the left and is followed by the three Arrhenius coefficients (pre-exponential factor, temperature exponent, and activation energy). Enhanced third body efficiencies for selected species are specified in the line following that for a reaction which contains an arbitrary third body, M. Exclamation marks signify the beginning of comments and the remainder of the line is ignored."

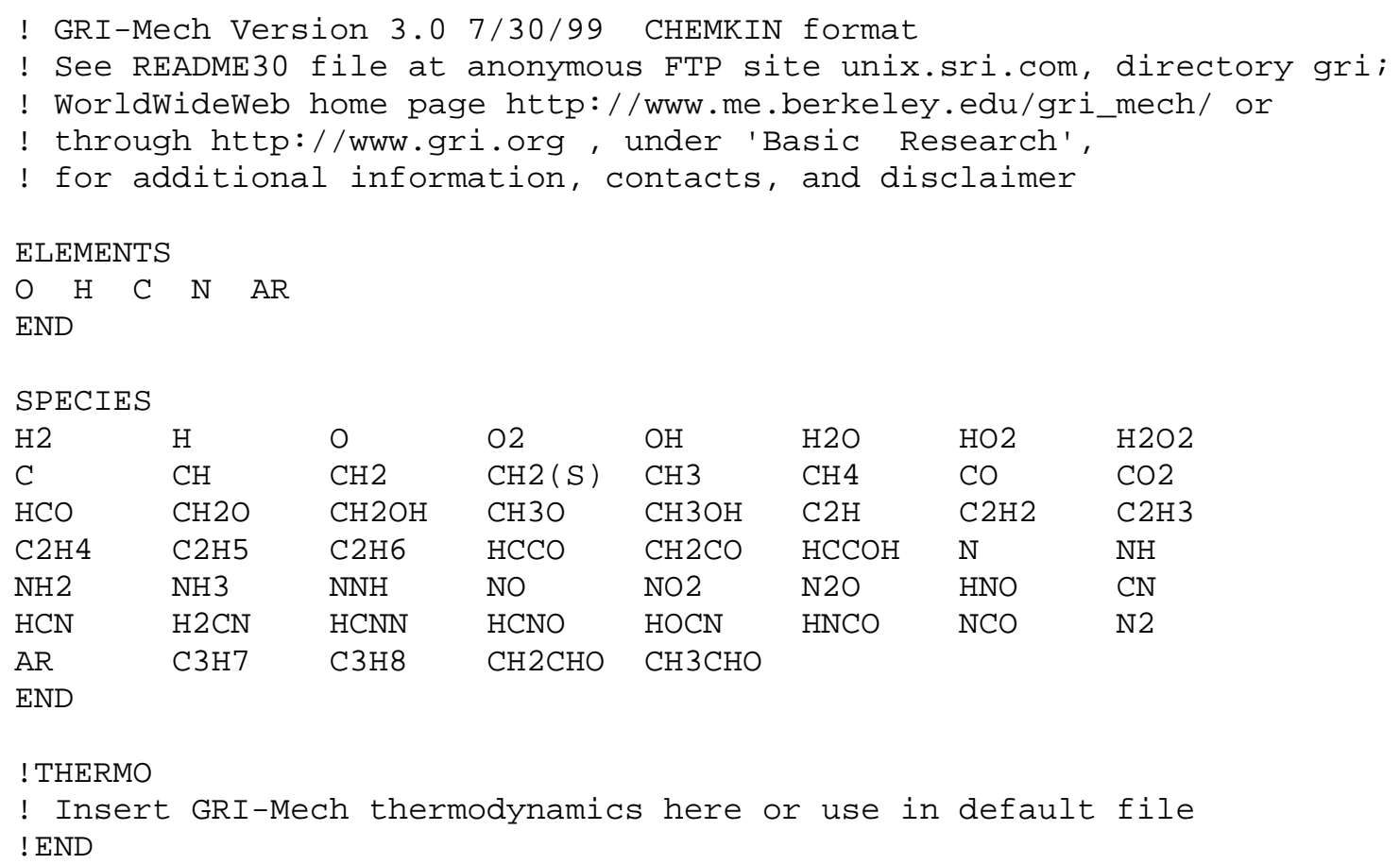




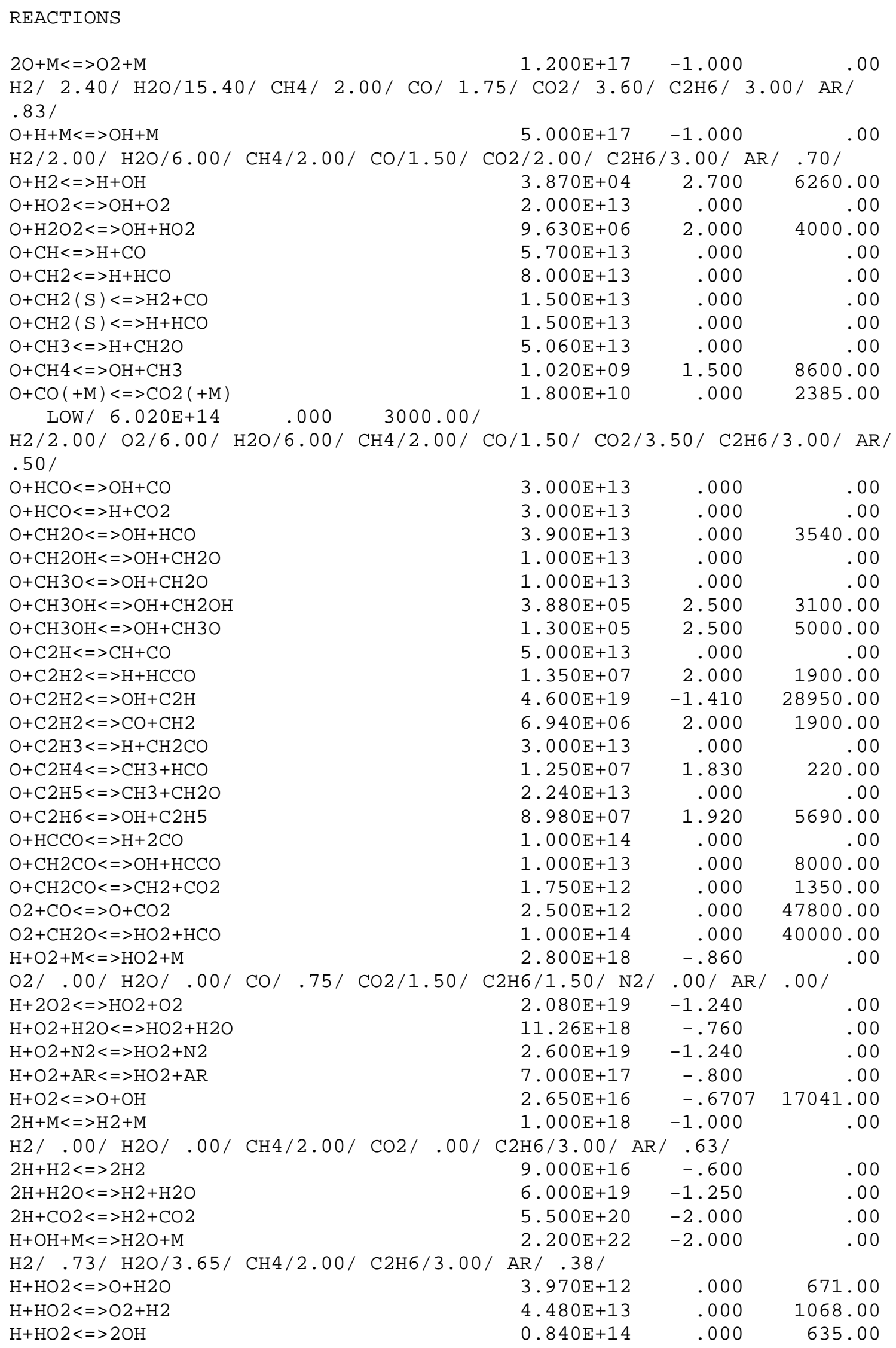




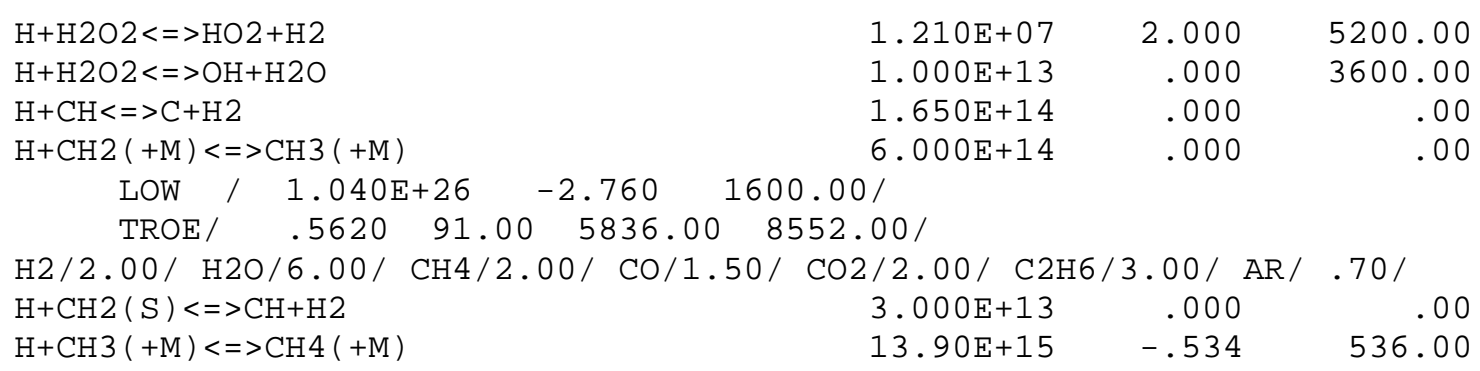

LOW / 2.620E+33 -4.760 2440.00/

TROE/ $\quad .7830 \quad 74.00 \quad 2941.00 \quad 6964.00 /$

$\mathrm{H} 2 / 2.00 / \mathrm{H} 2 \mathrm{O} / 6.00 / \mathrm{CH} 4 / 3.00 / \mathrm{CO} / 1.50 / \mathrm{CO} 2 / 2.00 / \mathrm{C} 2 \mathrm{H} 6 / 3.00 / \mathrm{AR} / .70 /$

$\begin{array}{llrr}\mathrm{H}+\mathrm{CH} 4<=>\mathrm{CH} 3+\mathrm{H} 2 & 6.600 \mathrm{E}+08 & 1.620 & 10840.00 \\ \mathrm{H}+\mathrm{HCO}(+\mathrm{M})<=>\mathrm{CH} 2 \mathrm{O}(+\mathrm{M}) & 1.090 \mathrm{E}+12 & .480 & -260.00\end{array}$

LOW / $2.470 \mathrm{E}+24 \quad-2.570 \quad 425.00 /$

TROE/ $\quad .7824 \quad 271.00 \quad 2755.00 \quad 6570.00 /$

$\mathrm{H} 2 / 2.0 \odot / \mathrm{H} 2 \mathrm{O} / 6.00 / \mathrm{CH} 4 / 2.00 / \mathrm{CO} / 1.50 / \mathrm{CO} 2 / 2.00 / \mathrm{C} 2 \mathrm{H} 6 / 3.0 \odot / \mathrm{AR} / \mathrm{.70} /$

$\mathrm{H}+\mathrm{HCO}<=>\mathrm{H} 2+\mathrm{CO} \quad 7.340 \mathrm{E}+13 \quad 000 \quad .000 \quad .00$

$\mathrm{H}+\mathrm{CH} 2 \mathrm{O}(+\mathrm{M})<=>\mathrm{CH} 2 \mathrm{OH}(+\mathrm{M}) \quad 5.400 \mathrm{E}+11 \quad .454 \quad 3600.00$

LOW / $1.270 \mathrm{E}+32 \quad-4.820 \quad 6530.00 /$

TROE/ . $1187 \quad 103.00 \quad 1291.00 \quad 4160.00 /$

$\mathrm{H} 2 / 2.00 / \mathrm{H} 20 / 6.00 / \mathrm{CH} 4 / 2.00 / \mathrm{CO} / 1.50 / \mathrm{CO} / 2.00 / \mathrm{C} 2 \mathrm{H} 6 / 3.00 /$

$\mathrm{H}+\mathrm{CH} 2 \mathrm{O}(+\mathrm{M})<=>\mathrm{CH} 30(+\mathrm{M}) \quad 5.400 \mathrm{E}+11 \quad .454 \quad 2600.00$

LOW / 2.200E+30 - $4.800 \quad 5560.00 /$

TROE/ $\quad .7580 \quad 94.00 \quad 1555.00 \quad 4200.00 /$

$\mathrm{H} 2 / 2.00 / \mathrm{H} 2 \mathrm{O} / 6.00 / \mathrm{CH} 4 / 2.00 / \mathrm{CO} / 1.50 / \mathrm{CO} 2 / 2.00 / \mathrm{C} 2 \mathrm{H} 6 / 3.00 /$

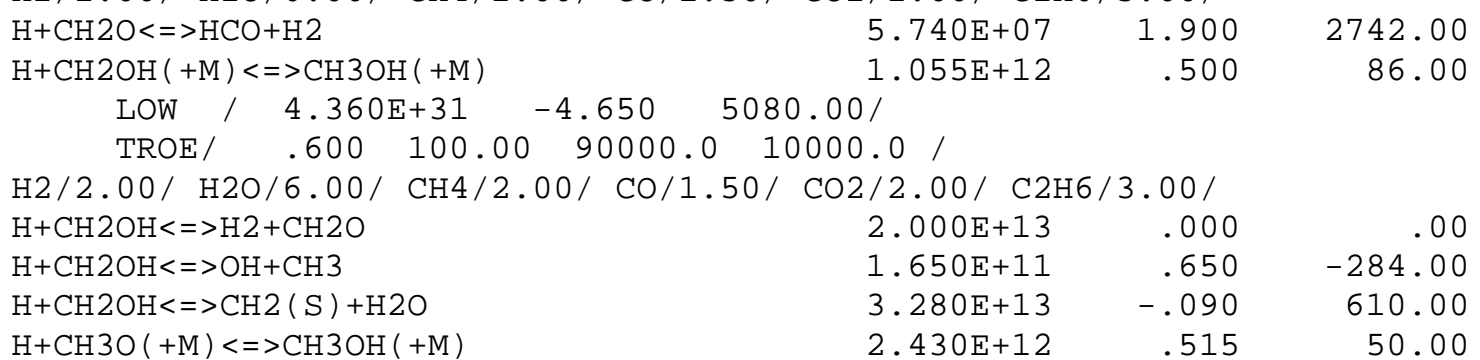

$\mathrm{H}+\mathrm{CH} 30(+\mathrm{M})<=>\mathrm{CH} 3 \mathrm{OH}(+\mathrm{M})$

LOW / 4.660E+41 $-7.440 \quad 14080.0 /$

TROE/ . $700 \quad 100.00 \quad 90000.010000 .00 /$

$\mathrm{H} 2 / 2.00 / \mathrm{H} 2 \mathrm{O} / 6.00 / \mathrm{CH} 4 / 2.00 / \mathrm{CO} / 1.50 / \mathrm{CO} 2 / 2.00 / \mathrm{C} 2 \mathrm{H} 6 / 3.0 \odot /$

$\begin{array}{lrrr}\mathrm{H}+\mathrm{CH} 30<=>\mathrm{H}+\mathrm{CH} 2 \mathrm{OH} & 4.150 \mathrm{E}+\odot 7 & 1.630 & 1924.00 \\ \mathrm{H}+\mathrm{CH} 30<=>\mathrm{H} 2+\mathrm{CH} 2 \mathrm{O} & 2.000 \mathrm{E}+13 & .00 \odot & .00 \\ \mathrm{H}+\mathrm{CH} 30<=>\mathrm{OH}+\mathrm{CH} 3 & 1.500 \mathrm{E}+12 & .50 \odot & -110.00 \\ \mathrm{H}+\mathrm{CH} 30<=>\mathrm{CH} 2(\mathrm{~S})+\mathrm{H} 20 & 2.620 \mathrm{E}+14 & -.230 & 1070.00 \\ \mathrm{H}+\mathrm{CH} 3 \mathrm{OH}<=>\mathrm{CH} 2 \mathrm{OH}+\mathrm{H} 2 & 1.700 \mathrm{E}+07 & 2.100 & 4870.00 \\ \mathrm{H}+\mathrm{CH} 3 \mathrm{OH}<=>\mathrm{CH} 30+\mathrm{H} 2 & 4.200 \mathrm{E}+\odot 6 & 2.10 \odot & 4870.00 \\ \mathrm{H}+\mathrm{C} 2 \mathrm{H}(+\mathrm{M})<=>\mathrm{C} 2 \mathrm{H} 2(+\mathrm{M}) & 1.000 \mathrm{E}+17 & -1.00 \odot & .00\end{array}$

LOW / 3.750E+33 $-4.800 \quad 1900.00 /$

TROE/ . $.6464 \quad 132.00 \quad 1315.00 \quad 5566.00 /$

$\mathrm{H} 2 / 2.00 / \mathrm{H} 2 \mathrm{O} / 6.00 / \mathrm{CH} 4 / 2.00 / \mathrm{CO} / 1.50 / \mathrm{CO} 2 / 2.00 / \mathrm{C} 2 \mathrm{H} 6 / 3.00 / \mathrm{AR} / \mathrm{.70} /$

$\mathrm{H}+\mathrm{C} 2 \mathrm{H} 2(+\mathrm{M})<=>\mathrm{C} 2 \mathrm{H} 3(+\mathrm{M}) \quad 5.600 \mathrm{E}+12 \quad .000 \quad 2400.00$ LOW / 3.800E+40 -7.270 7220.00/

TROE/ $.7507 \quad 98.50 \quad 1302.00 \quad 4167.00 /$

$\mathrm{H} 2 / 2.00 / \mathrm{H} 2 \mathrm{O} / 6.00 / \mathrm{CH} 4 / 2.00 / \mathrm{CO} / 1.50 / \mathrm{CO} 2 / 2.00 / \mathrm{C} 2 \mathrm{H} 6 / 3.00 / \mathrm{AR} / \mathrm{.70} /$

$\mathrm{H}+\mathrm{C} 2 \mathrm{H} 3(+\mathrm{M})<=>\mathrm{C} 2 \mathrm{H} 4(+\mathrm{M}) \quad 6.080 \mathrm{E}+12 \quad .270 \quad 280.00$

LOW / $1.400 \mathrm{E}+30-3.860 \quad 3320.00 /$

TROE/ $\quad .7820 \quad 207.50 \quad 2663.00 \quad 6095.00 /$

$\mathrm{H} 2 / 2.00 / \mathrm{H} 2 \mathrm{O} / 6.00 / \mathrm{CH} 4 / 2.00 / \mathrm{CO} / 1.50 / \mathrm{CO} 2 / 2.00 / \mathrm{C} 2 \mathrm{H} 6 / 3.00 / \mathrm{AR} / \mathrm{.70} /$

$\mathrm{H}+\mathrm{C} 2 \mathrm{H} 3<=>\mathrm{H} 2+\mathrm{C} 2 \mathrm{H} 2$

$3.000 \mathrm{E}+13 \quad .000$

.00 


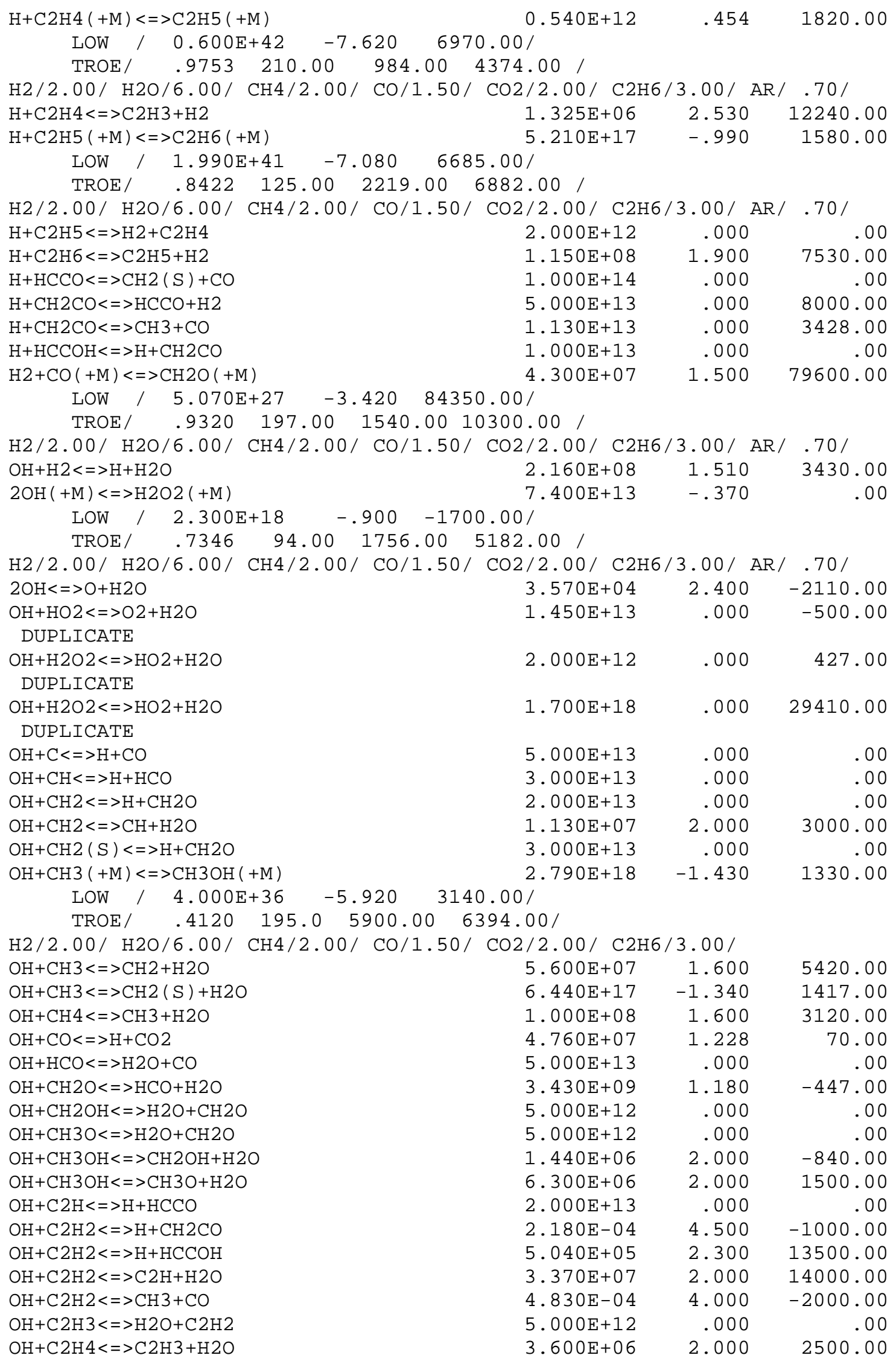




\begin{tabular}{|c|c|c|c|}
\hline $\mathrm{OH}+\mathrm{C} 2 \mathrm{H} 6<=>\mathrm{C} 2 \mathrm{H} 5+\mathrm{H} 2 \mathrm{O}$ & $3.540 E+06$ & 2.120 & 870.00 \\
\hline $\mathrm{OH}+\mathrm{CH} 2 \mathrm{CO}<=>\mathrm{HCCO}+\mathrm{H} 2 \mathrm{O}$ & $7.500 \mathrm{E}+12$ & .000 & 2000.00 \\
\hline $\begin{array}{l}2 \mathrm{HO} 2<=>02+\mathrm{H} 2 \mathrm{O} 2 \\
\text { DUPLICATE }\end{array}$ & 1. $300 \mathrm{E}+11$ & .000 & -1630.00 \\
\hline $\begin{array}{l}2 \mathrm{HO} 2<=>02+\mathrm{H} 2 \mathrm{O} 2 \\
\text { DUPLICATE }\end{array}$ & $4.200 \mathrm{E}+14$ & .000 & 12000.00 \\
\hline $\mathrm{HO} 2+\mathrm{CH} 2<=>\mathrm{OH}+\mathrm{CH} 2 \mathrm{O}$ & $2.000 E+13$ & .000 & .00 \\
\hline $\mathrm{HO} 2+\mathrm{CH} 3<=>02+\mathrm{CH} 4$ & 1. $000 \mathrm{E}+12$ & .000 & $.0 \odot$ \\
\hline $\mathrm{HO} 2+\mathrm{CH} 3<=>\mathrm{OH}+\mathrm{CH} 3 \mathrm{O}$ & $3.780 \mathrm{E}+13$ & $.00 \odot$ & $.0 \odot$ \\
\hline $\mathrm{HO} 2+\mathrm{CO}<=>\mathrm{OH}+\mathrm{CO} 2$ & $1.500 \mathrm{E}+14$ & .000 & 23600.00 \\
\hline $\mathrm{HO} 2+\mathrm{CH} 2 \mathrm{O}<=>\mathrm{HCO}+\mathrm{H} 2 \mathrm{O} 2$ & $5.6 \odot \odot E+\odot 6$ & $2.00 \odot$ & $1200 \odot . \odot \odot$ \\
\hline$C+02<=>0+C 0$ & $5.800 \mathrm{E}+13$ & $.00 \odot$ & $576.0 \odot$ \\
\hline $\mathrm{C}+\mathrm{CH} 2<=>\mathrm{H}+\mathrm{C} 2 \mathrm{H}$ & $5.000 \mathrm{E}+13$ & .000 & $.0 \odot$ \\
\hline $\mathrm{C}+\mathrm{CH} 3<=>\mathrm{H}+\mathrm{C} 2 \mathrm{H} 2$ & $5.000 \mathrm{E}+13$ & .000 & $.0 \odot$ \\
\hline $\mathrm{CH}+02<=>0+\mathrm{HCO}$ & $\mathrm{EE}+13$ & $.00 \odot$ & .00 \\
\hline $\mathrm{CH}+\mathrm{H} 2<=>\mathrm{H}+\mathrm{CH} 2$ & $\mathrm{EE}+14$ & $.00 \odot$ & 3110.00 \\
\hline $\mathrm{CH}+\mathrm{H} 2 \mathrm{O}<=>\mathrm{H}+\mathrm{CH} 2 \mathrm{O}$ & ๑E+12 & $.00 \odot$ & $-755 . \odot \odot$ \\
\hline $\mathrm{CH}+\mathrm{CH} 2<=>\mathrm{H}+\mathrm{C} 2 \mathrm{H} 2$ & 4. $000 \mathrm{E}+13$ & $.00 \odot$ &.$\odot \odot$ \\
\hline $\mathrm{CH}+\mathrm{CH} 3<=>\mathrm{H}+\mathrm{C} 2 \mathrm{H} 3$ & $3.000 \mathrm{E}+13$ & $.00 \odot$ &.$\odot \odot$ \\
\hline $\mathrm{CH}+\mathrm{CH} 4<=>\mathrm{H}+\mathrm{C} 2 \mathrm{H} 4$ & $\mathrm{E}+13$ & $.00 \odot$ &.$\odot \odot$ \\
\hline $\mathrm{CH}+\mathrm{CO}(+\mathrm{M})<=>\mathrm{HCCO}(+\mathrm{M})$ & $5.00 \odot \mathrm{E}+13$ & $.00 \odot$ & $.0 \odot$ \\
\hline LoW / $2.690 \mathrm{E}+28$ & $1936.0 \odot /$ & & \\
\hline $\begin{array}{lll}\text { TROE/ } & .5757 & 237.0 \odot\end{array}$ & $1652.00 \quad 5069.00 /$ & & \\
\hline $\mathrm{H} 2 / 2.0 \odot / \mathrm{H} 2 \mathrm{O} / 6.0 \odot / \mathrm{CH} 4 / 2 . \mathrm{O}$ & / $\mathrm{CO} / 1.50 / \mathrm{CO} 2 / 2.00 / \mathrm{C} 2 \mathrm{H}$ & $3.00 / \mathrm{AR} /$ & $/ .70 /$ \\
\hline $\mathrm{CH}+\mathrm{CO} 2<=>\mathrm{HCO}+\mathrm{CO}$ & $1.900 \mathrm{E}+14$ & .000 & 15792.00 \\
\hline $\mathrm{CH}+\mathrm{CH} 2 \mathrm{O}<=>\mathrm{H}+\mathrm{CH} 2 \mathrm{CO}$ & $\mathrm{gE}+13$ & $.0 \odot \odot$ & -515.00 \\
\hline $\mathrm{CH}+\mathrm{HCCO}<=>\mathrm{CO}+\mathrm{C} 2 \mathrm{H} 2$ & $E+13$ & .000 & .00 \\
\hline $\mathrm{CH} 2+02=>0 \mathrm{H}+\mathrm{H}+\mathrm{CO}$ & $E+12$ & .000 & $1500 . \odot \odot$ \\
\hline $\mathrm{CH} 2+\mathrm{H} 2<=>\mathrm{H}+\mathrm{CH} 3$ & $5.00 \odot E+\odot 5$ & $2.00 \odot$ & $7230 . \odot \odot$ \\
\hline $2 \mathrm{CH} 2<=>\mathrm{H} 2+\mathrm{C} 2 \mathrm{H} 2$ & $1.600 \mathrm{E}+15$ & .000 & 11944.00 \\
\hline $\mathrm{CH} 2+\mathrm{CH} 3<=>\mathrm{H}+\mathrm{C} 2 \mathrm{H} 4$ & 4. $000 \mathrm{E}+13$ & .000 & $.0 \odot$ \\
\hline $\mathrm{CH} 2+\mathrm{CH} 4<=>2 \mathrm{CH} 3$ & $E+06$ & 2.000 & 8270.00 \\
\hline $\mathrm{CH} 2+\mathrm{CO}(+\mathrm{M})<=>\mathrm{CH} 2 \mathrm{CO}(+\mathrm{M})$ & $8.100 \mathrm{E}+11$ & .500 & 4510.00 \\
\hline LOW / 2.690E+33 & $7095.00 /$ & & \\
\hline TROE/ $\quad .5907 \quad 275.00$ & $1226.00 \quad 5185.00 /$ & & \\
\hline $\mathrm{H} 2 / 2.00 / \mathrm{H} 2 \mathrm{O} / 6.00 / \mathrm{CH} 4 / 2 . \mathrm{OC}$ & $/ \mathrm{CO} / 1.50 / \mathrm{CO} 2 / 2.00 / \mathrm{C} 2 \mathrm{H}$ & $/ 3.00 / \mathrm{AR} /$ & $.70 /$ \\
\hline $\mathrm{CH} 2+\mathrm{HCCO}<=>\mathrm{C} 2 \mathrm{H} 3+\mathrm{CO}$ & 3. $\odot \odot \odot E+13$ & $.0 \odot \odot$ &.$\odot \odot$ \\
\hline $\mathrm{CH} 2(\mathrm{~S})+\mathrm{N} 2<=>\mathrm{CH} 2+\mathrm{N} 2$ & $1.500 \mathrm{E}+13$ & $.00 \odot$ & 600.00 \\
\hline S) $+\mathrm{AR}<=>\mathrm{CH} 2+\mathrm{AR}$ & $\mathrm{OE}+12$ & .000 & 600.00 \\
\hline $\mathrm{CH} 2(\mathrm{~S})+02<=>\mathrm{H}+\mathrm{OH}+\mathrm{CO}$ & $0 E+13$ & $.00 \odot$ &.$\odot \odot$ \\
\hline $\mathrm{CH} 2(\mathrm{~S})+02<=>\mathrm{CO}+\mathrm{H} 2 \mathrm{O}$ & $1.200 \mathrm{E}+13$ & .000 & $.0 \odot$ \\
\hline $\mathrm{CH} 2(\mathrm{~S})+\mathrm{H} 2<=>\mathrm{CH} 3+\mathrm{H}$ & $7.000 \mathrm{E}+13$ & .000 & .00 \\
\hline $\mathrm{CH} 2(\mathrm{~S})+\mathrm{H} 2 \mathrm{O}(+\mathrm{M})<=>\mathrm{CH} 3 \mathrm{OH}(+\mathrm{M})$ & $4.820 \mathrm{E}+17$ & -1.160 & $1145.0 \odot$ \\
\hline LOW / 1.880E+38 - 6 & $.360 \quad 5040.0 \odot /$ & & \\
\hline $\begin{array}{lll}\text { TROE/ } & .6027 & 208.00\end{array}$ & $3922.00 \quad 10180.0 /$ & & \\
\hline $\mathrm{H} 2 / 2.00 / \mathrm{H} 2 \mathrm{O} / 6.0 \mathrm{O} / \mathrm{CH} 4 / 2 . \mathrm{O}$ & $/ \mathrm{CO} / 1.50 / \mathrm{CO} 2 / 2.00 / \mathrm{C} 2$ & $.00 /$ & \\
\hline $\mathrm{CH} 2(\mathrm{~S})+\mathrm{H} 2 \mathrm{O}<=>\mathrm{CH} 2+\mathrm{H} 2 \mathrm{O}$ & $3.000 \mathrm{E}+13$ & .000 & .00 \\
\hline $\mathrm{CH} 2(\mathrm{~S})+\mathrm{CH} 3<=>\mathrm{H}+\mathrm{C} 2 \mathrm{H} 4$ & 1. $200 \mathrm{E}+13$ & $.0 \odot \odot$ & -570.00 \\
\hline $\mathrm{CH} 2(\mathrm{~S})+\mathrm{CH} 4<=>2 \mathrm{CH} 3$ & $1.600 \mathrm{E}+13$ & $.00 \odot$ & -570.00 \\
\hline $\mathrm{CH} 2(\mathrm{~S})+\mathrm{CO}<=>\mathrm{CH} 2+\mathrm{CO}$ & כE+12 & .000 & $.0 \odot$ \\
\hline S) $+\mathrm{CO} 2<=>\mathrm{CH} 2+\mathrm{CO} 2$ & $7.000 \mathrm{E}+12$ & .000 & .00 \\
\hline $\mathrm{CH} 2(\mathrm{~S})+\mathrm{CO} 2<=>\mathrm{CO}+\mathrm{CH} 2 \mathrm{O}$ & 1. $400 \mathrm{E}+13$ & $.0 \odot \odot$ & $.0 \odot$ \\
\hline $\mathrm{CH} 2(\mathrm{~S})+\mathrm{C} 2 \mathrm{H} 6<=>\mathrm{CH} 3+\mathrm{C} 2 \mathrm{H} 5$ & $4.000 \mathrm{E}+13$ & $.00 \odot$ & -550.00 \\
\hline $\mathrm{CH} 3+02<=>0+\mathrm{CH} 3 \mathrm{O}$ & $3.560 E+13$ & .000 & 30480.00 \\
\hline $\mathrm{CH} 3+02<=>\mathrm{OH}+\mathrm{CH} 2 \mathrm{O}$ & $2.310 E+12$ & $.00 \odot$ & $20315 . \odot \odot$ \\
\hline $\mathrm{CH} 3+\mathrm{H} 2 \mathrm{O} 2<=>\mathrm{HO} 2+\mathrm{CH} 4$ & $2.450 \mathrm{E}+\odot 4$ & 2.470 & 5180.00 \\
\hline $2 \mathrm{CH} 3(+\mathrm{M})<=>\mathrm{C} 2 \mathrm{H} 6(+\mathrm{M})$ & $6.770 \mathrm{E}+16$ & -1.180 & 654.00 \\
\hline
\end{tabular}




$$
\begin{array}{lllll}
\text { LOW / } & 3.400 E+41 & -7.030 & 2762.00 / \\
\text { TROE/ } & .6190 & 73.20 & 1180.00 & 9999.00 /
\end{array}
$$

\begin{tabular}{|c|c|c|c|}
\hline $2 \mathrm{CH} 3<=>\mathrm{H}+\mathrm{C} 2 \mathrm{H} 5$ & $6.840 \mathrm{E}+12$ & .100 & 10600.00 \\
\hline $\mathrm{CH} 3+\mathrm{HCO}<=>\mathrm{CH} 4+\mathrm{CO}$ & $2.648 \mathrm{E}+13$ & .000 & $.0 \odot$ \\
\hline $\mathrm{CH} 3+\mathrm{CH} 2 \mathrm{O}<=>\mathrm{HCO}+\mathrm{CH} 4$ & $3.320 \mathrm{E}+03$ & 2.810 & 5860.00 \\
\hline $\mathrm{CH} 3+\mathrm{CH} 3 \mathrm{OH}<=>\mathrm{CH} 2 \mathrm{OH}+\mathrm{CH} 4$ & $3.00 \odot E+\odot 7$ & 1.500 & 9940.00 \\
\hline $\mathrm{CH} 3+\mathrm{CH} 3 \mathrm{OH}<=>\mathrm{CH} 3 \mathrm{O}+\mathrm{CH} 4$ & $1.000 \mathrm{E}+07$ & 1.500 & 9940.00 \\
\hline $\mathrm{CH} 3+\mathrm{C} 2 \mathrm{H} 4<=>\mathrm{C} 2 \mathrm{H} 3+\mathrm{CH} 4$ & $2.270 \mathrm{E}+05$ & 2.000 & 9200.00 \\
\hline $\mathrm{CH} 3+\mathrm{C} 2 \mathrm{H} 6<=>\mathrm{C} 2 \mathrm{H} 5+\mathrm{CH} 4$ & $6.140 \mathrm{E}+06$ & 1.740 & 10450.00 \\
\hline $\mathrm{HCO}+\mathrm{H} 2 \mathrm{O}<=>\mathrm{H}+\mathrm{CO}+\mathrm{H} 2 \mathrm{O}$ & $1.500 \mathrm{E}+18$ & $-1.00 \odot$ & $1700 \odot . \odot \odot$ \\
\hline $\mathrm{HCO}+\mathrm{M}<=>\mathrm{H}+\mathrm{CO}+\mathrm{M}$ & $1.870 \mathrm{E}+17$ & $-1.0 \odot \odot$ & 17000.00 \\
\hline $\mathrm{H} 2 / 2.0 \odot / \mathrm{H} 2 \mathrm{O} / \mathrm{.0} / \mathrm{CH} 4 / 2.00 / \mathrm{CO} / 1.50 /$ & $\mathrm{CO} 2 / 2.0 \odot / \mathrm{C} 2 \mathrm{H}$ & $/ 3.00 /$ & \\
\hline $\mathrm{HCO}+02<=>\mathrm{HO} 2+\mathrm{CO}$ & $13 \cdot 45 \mathrm{E}+12$ & $.00 \odot$ & 400.00 \\
\hline $\mathrm{CH} 2 \mathrm{OH}+02<=>\mathrm{HO} 2+\mathrm{CH} 2 \mathrm{O}$ & $1.800 \mathrm{E}+13$ & .000 & 900.00 \\
\hline $2<=>\mathrm{HO} 2+\mathrm{CH} 2 \mathrm{O}$ & OE-13 & 7.600 & -3530.00 \\
\hline $\mathrm{C} 2 \mathrm{H}+02<=>\mathrm{HCO}+\mathrm{CO}$ & $1.000 \mathrm{E}+13$ & $.0 \odot \odot$ & $-755.0 \odot$ \\
\hline $\mathrm{C} 2 \mathrm{H}+\mathrm{H} 2<=>\mathrm{H}+\mathrm{C} 2 \mathrm{H} 2$ & $5.680 \mathrm{E}+10$ & $\odot .90 \odot$ & 1993.00 \\
\hline $\mathrm{C} 2 \mathrm{H} 3+02<=>\mathrm{HCO}+\mathrm{CH} 2 \mathrm{O}$ & $4.580 E+16$ & -1.390 & 1015.00 \\
\hline $\mathrm{C} 2 \mathrm{H} 4(+\mathrm{M})<=>\mathrm{H} 2+\mathrm{C} 2 \mathrm{H} 2(+\mathrm{M})$ & $8.000 \mathrm{E}+12$ & .440 & $86770.0 \odot$ \\
\hline
\end{tabular}

LOW / 1.580E+51 -9.300 97800.00/

TROE/ . . $7345 \quad 180.00 \quad 1035.00 \quad 5417.00 /$

\begin{tabular}{|c|c|c|c|}
\hline $\mathrm{C} 2 \mathrm{H} 5+02<=>\mathrm{HO} 2+\mathrm{C} 2 \mathrm{H} 4$ & $8.400 \mathrm{E}+11$ & .000 & 3875.00 \\
\hline $\mathrm{HCCO}+02<=>0 \mathrm{H}+2 \mathrm{CO}$ & 3. 200E+12 & .000 & 854.00 \\
\hline $2 \mathrm{HCCO}<=>2 \mathrm{CO}+\mathrm{C} 2 \mathrm{H} 2$ & 1. $000 \mathrm{E}+13$ & .000 & $.0 \odot$ \\
\hline $\mathrm{N}+\mathrm{NO}<=>\mathrm{N} 2+0$ & $2.700 \mathrm{E}+13$ & .000 & 355.00 \\
\hline $\mathrm{N}+02<=>\mathrm{NO}+0$ & 9. $\odot \odot \odot E+\odot 9$ & 1.000 & 6500.00 \\
\hline $\mathrm{N}+\mathrm{OH}<=>\mathrm{NO}+\mathrm{H}$ & $3.360 E+13$ & .000 & 385.00 \\
\hline $\mathrm{N} 20+0<=>\mathrm{N} 2+02$ & 1. $400 \mathrm{E}+12$ & .000 & 10810.00 \\
\hline $\mathrm{N} 20+0<=>2 \mathrm{NO}$ & $2.900 \mathrm{E}+13$ & .000 & 23150.00 \\
\hline $\mathrm{N} 2 \mathrm{O}+\mathrm{H}<=>\mathrm{N} 2+\mathrm{OH}$ & $3.870 \mathrm{E}+14$ & .000 & 18880.00 \\
\hline $\mathrm{N} 20+\mathrm{OH}<=>\mathrm{N} 2+\mathrm{H} 02$ & 2. $\odot \odot \odot E+12$ & .000 & 21060.00 \\
\hline $\mathrm{N} 20(+\mathrm{M})<=>\mathrm{N} 2+\mathrm{O}(+\mathrm{M})$ & $7.910 \mathrm{E}+10$ & .000 & 56020.00 \\
\hline
\end{tabular}

$\mathrm{H} 2 / 2.00 / \mathrm{H} 2 \mathrm{O} / 6.00 / \mathrm{CH} 4 / 2.00 / \mathrm{CO} / 1.50 / \mathrm{CO} / 2.00 / \mathrm{C} 2 \mathrm{H} 6 / 3.00 / \mathrm{AR} / .70 /$ LOW / 6.370E+14 .000 56640.00/

\begin{tabular}{|c|c|c|c|}
\hline $\mathrm{HO} 2+\mathrm{NO}<=>\mathrm{NO} 2+\mathrm{OH}$ & $2.110 \mathrm{E}+12$ &.$\odot \odot \odot$ & $-480 . \odot \odot$ \\
\hline $\mathrm{NO}+\mathrm{O}+\mathrm{M}<=>\mathrm{NO} 2+\mathrm{M}$ & $1.060 \mathrm{E}+20$ & -1.410 & .00 \\
\hline $\mathrm{H} 2 / 2.0 \odot / \mathrm{H} 20 / 6.0 \odot / \mathrm{CH} 4 / 2.0 \odot / \mathrm{CO} / 1.5 \odot /$ & $\mathrm{C} 02 / 2.0 \odot / \mathrm{C} 2$ & (3.0०/ AR/ & $.70 /$ \\
\hline $\mathrm{NO} 2+\mathrm{O}<=>\mathrm{NO}+02$ & $3.900 \mathrm{E}+12$ & .000 & -240.00 \\
\hline $\mathrm{NO} 2+\mathrm{H}<=>\mathrm{NO}+\mathrm{OH}$ & $1.320 E+14$ & .000 & $360.0 \odot$ \\
\hline $\mathrm{NH}+\mathrm{O}<=>\mathrm{NO}+\mathrm{H}$ & $4.0 \odot \odot E+13$ & $.0 \odot \odot$ & .00 \\
\hline $\mathrm{NH}+\mathrm{H}<=>\mathrm{N}+\mathrm{H} 2$ & $3.200 \mathrm{E}+13$ & .000 & 330.00 \\
\hline $\mathrm{NH}+\mathrm{OH}<=>\mathrm{HNO}+\mathrm{H}$ & $2.000 \mathrm{E}+13$ & .000 & .0 \\
\hline $\mathrm{NH}+\mathrm{OH}<=>\mathrm{N}+\mathrm{H} 2 \mathrm{O}$ & $2.000 \mathrm{E}+09$ & 1.200 & .0 \\
\hline $\mathrm{NH}+02<=>\mathrm{HNO}+0$ & $4.610 E+05$ & 2.000 & 6500.00 \\
\hline $\mathrm{NH}+02<=>\mathrm{NO}+\mathrm{OH}$ & 1. 280E+06 & 1.500 & 100.00 \\
\hline $\mathrm{NH}+\mathrm{N}<=>\mathrm{N} 2+\mathrm{H}$ & $1.500 \mathrm{E}+13$ & $.0 \odot \odot$ & .0 \\
\hline $\mathrm{NH}+\mathrm{H} 2 \mathrm{O}<=>\mathrm{HNO}+\mathrm{H} 2$ & $2.000 \mathrm{E}+13$ & .000 & 13850.0 \\
\hline $\mathrm{NH}+\mathrm{NO}<=>\mathrm{N} 2+\mathrm{OH}$ & $2.160 \mathrm{E}+13$ & -.230 &.$\odot$ \\
\hline $\mathrm{NH}+\mathrm{NO}<=>\mathrm{N} 2 \mathrm{O}+\mathrm{H}$ & $3.650 \mathrm{E}+14$ & -.450 & .0 \\
\hline $\mathrm{NH} 2+\mathrm{O}<=>\mathrm{OH}+\mathrm{NH}$ & 3. $000 \mathrm{E}+12$ & .000 & .0 \\
\hline $\mathrm{NH} 2+\mathrm{O}<=>\mathrm{H}+\mathrm{HNO}$ & $3.900 \mathrm{E}+13$ & .000 & .0 \\
\hline $\mathrm{NH} 2+\mathrm{H}<=>\mathrm{NH}+\mathrm{H} 2$ & $4.000 \mathrm{E}+13$ & .000 & 3650.00 \\
\hline $\mathrm{NH} 2+\mathrm{OH}<=>\mathrm{NH}+\mathrm{H} 2 \mathrm{O}$ & $9.000 \mathrm{E}+07$ & 1.500 & -460.0 \\
\hline $\mathrm{NNH}<=>\mathrm{N} 2+\mathrm{H}$ & $3.300 E+08$ & .000 & .0 \\
\hline $\mathrm{NNH}+\mathrm{M}<=>\mathrm{N} 2+\mathrm{H}+\mathrm{M}$ & 1. $300 \mathrm{E}+14$ & -.110 & 4980.0 \\
\hline
\end{tabular}

$\mathrm{H} 2 / 2.00 / \mathrm{H} 20 / 6.00 / \mathrm{CH} 4 / 2.00 / \mathrm{CO} / 1.50 / \mathrm{CO} 2 / 2.00 / \mathrm{C} 2 \mathrm{H} 6 / 3.00 / \mathrm{AR} / \mathrm{C25} /$ 


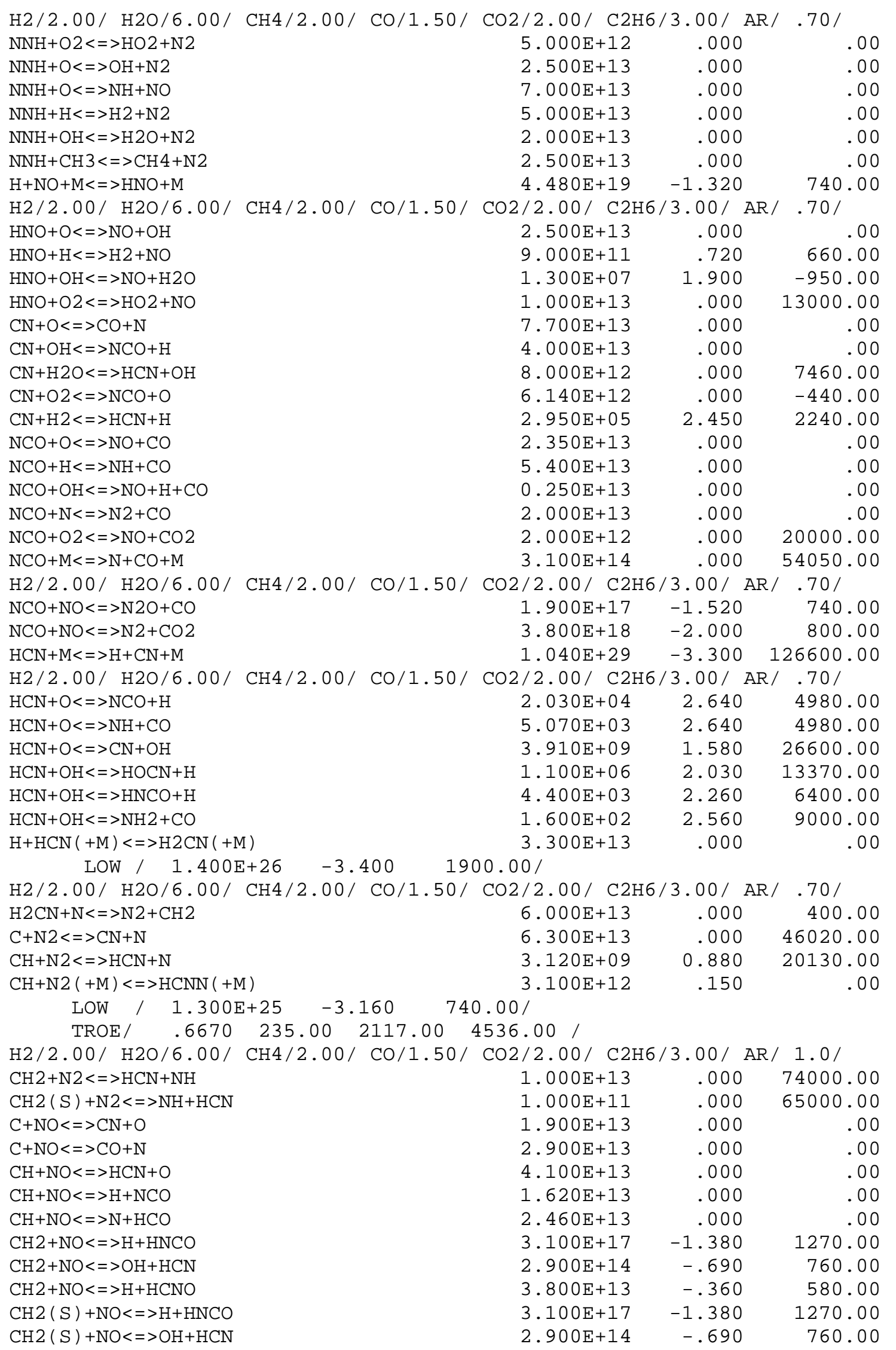




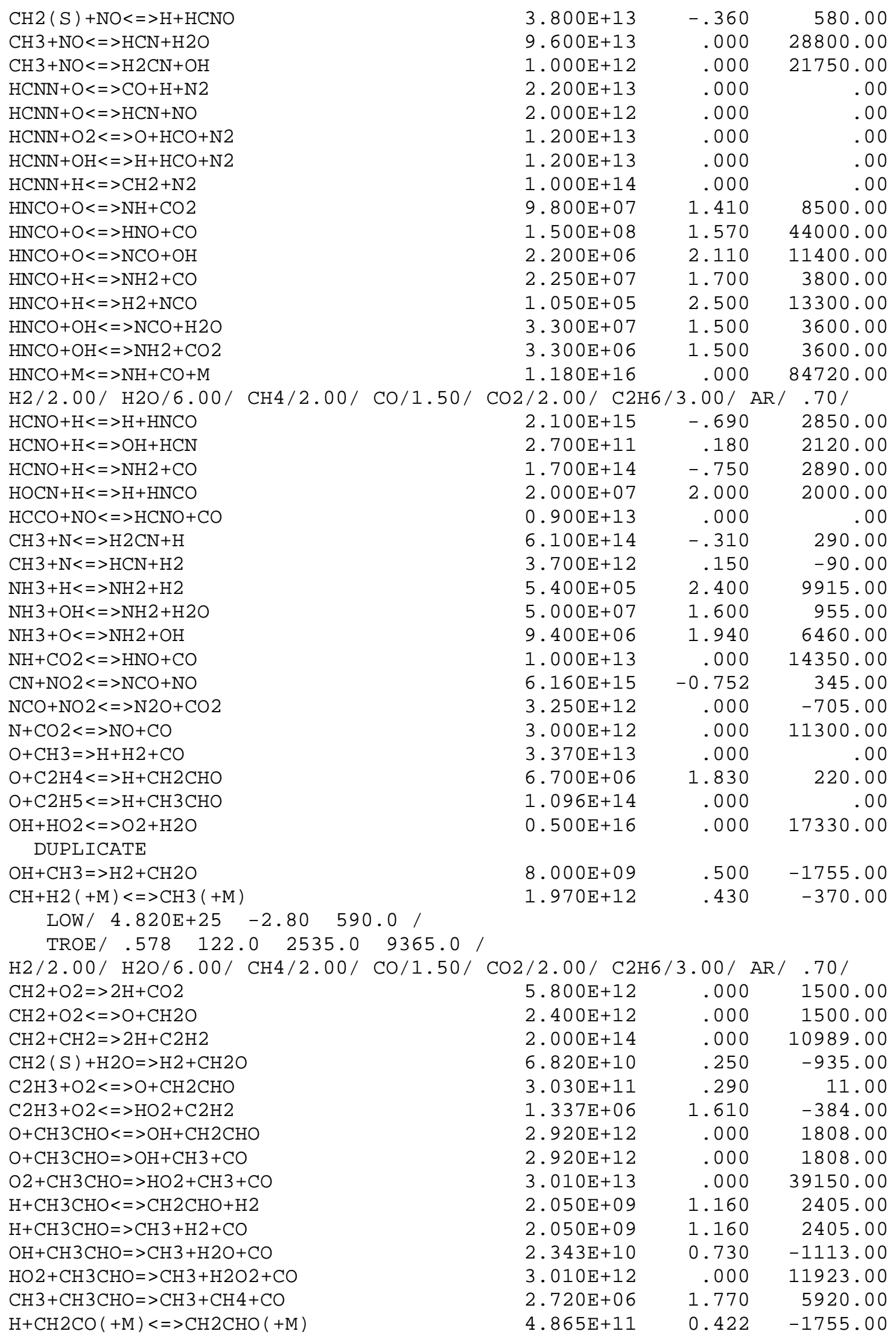


TROE/ $0.465 \quad 201.0 \quad 1773.0 \quad 5333.0 /$

$\mathrm{H} 2 / 2.0 \odot / \mathrm{H} 2 \mathrm{O} / 6.0 \odot / \mathrm{CH} 4 / 2.0 \odot / \mathrm{CO} / 1.50 / \mathrm{CO} / 2.0 \odot / \mathrm{C} 2 \mathrm{H} 6 / 3.0 \odot / \mathrm{AR} / \mathrm{.70} /$

$\mathrm{O}+\mathrm{CH} 2 \mathrm{CHO}=>\mathrm{H}+\mathrm{CH} 2+\mathrm{CO} 2$

$\mathrm{O} 2+\mathrm{CH} 2 \mathrm{CHO}=>\mathrm{OH}+\mathrm{CO}+\mathrm{CH} 2 \mathrm{O}$

$\mathrm{O} 2+\mathrm{CH} 2 \mathrm{CHO}=>\mathrm{OH}+2 \mathrm{HCO}$

$\mathrm{H}+\mathrm{CH} 2 \mathrm{CHO}<=>\mathrm{CH} 3+\mathrm{HCO}$

$\mathrm{H}+\mathrm{CH} 2 \mathrm{CHO}<=>\mathrm{CH} 2 \mathrm{CO}+\mathrm{H} 2$

$1.500 \mathrm{E}+14 \quad .000 \quad .00$

$\mathrm{OH}+\mathrm{CH} 2 \mathrm{CHO}<=>\mathrm{H} 2 \mathrm{O}+\mathrm{CH} 2 \mathrm{CO}$

$1.810 \mathrm{E}+10 \quad .000 \quad .00$

$\mathrm{OH}+\mathrm{CH} 2 \mathrm{CHO}<=>\mathrm{HCO}+\mathrm{CH} 2 \mathrm{OH}$

$\mathrm{CH} 3+\mathrm{C} 2 \mathrm{H} 5(+\mathrm{M})<=>\mathrm{C} 3 \mathrm{H} 8(+\mathrm{M})$

LOW/ 2.710E+74 $-16.82 \quad 13065.0 /$

$2.350 \mathrm{E}+10 \quad .000 \quad .00$

$2.200 \mathrm{E}+13 \quad .000 \quad .00$

$1.100 \mathrm{E}+13 \quad .000 \quad .0 \odot$

$1.200 \mathrm{E}+13 \quad .000 \quad .00$

3. $010 \mathrm{E}+13 \quad .000 \quad .00$

$\begin{array}{lll}.9430 \mathrm{E}+13 \quad .000 & .00\end{array}$

TROE/. $1527 \quad 291.0 \quad 2742.0 \quad 7748.0 /$

$\mathrm{H} 2 / 2.00 / \mathrm{H} 2 \mathrm{O} / 6.00 / \mathrm{CH} 4 / 2.00 / \mathrm{CO} / 1.50 / \mathrm{CO} / 2.0 \odot / \mathrm{C} 2 \mathrm{H} 6 / 3.00 / \mathrm{AR} / .70 /$

$0+\mathrm{C} 3 \mathrm{H} 8<=>\mathrm{OH}+\mathrm{C} 3 \mathrm{H} 7 \quad 1.930 \mathrm{E}+05 \quad 2.680 \quad 3716.00$

$\mathrm{H}+\mathrm{C} 3 \mathrm{H} 8<=>\mathrm{C} 3 \mathrm{H} 7+\mathrm{H} 2$

$1.320 \mathrm{E}+06 \quad 2.540 \quad 6756.00$

$\mathrm{OH}+\mathrm{C} 3 \mathrm{H} 8<=>\mathrm{C} 3 \mathrm{H} 7+\mathrm{H} 2 \mathrm{O}$

$3.160 \mathrm{E}+07$

1.800

934.00

$\mathrm{C} 3 \mathrm{H} 7+\mathrm{H} 2 \mathrm{O} 2<=>\mathrm{HO} 2+\mathrm{C} 3 \mathrm{H} 8$

$3.780 \mathrm{E}+02 \quad 2.720 \quad 1500.00$

$\mathrm{CH} 3+\mathrm{C} 3 \mathrm{H} 8<=>\mathrm{C} 3 \mathrm{H} 7+\mathrm{CH} 4$

$\odot .903 \mathrm{E}+0 \odot \quad 3.650 \quad 7154.00$

$\mathrm{CH} 3+\mathrm{C} 2 \mathrm{H} 4(+\mathrm{M})<=>\mathrm{C} 3 \mathrm{H} 7(+\mathrm{M})$

LOW/ 3.00E+63 $-14.6 \quad 18170 . /$

2.550E+०6 $1.600 \quad 5700.00$

TROE/ .1894 277.0 8748.0 7891.0/

$\mathrm{H} 2 / 2.0 \odot / \mathrm{H} 2 \mathrm{O} / 6.0 \odot / \mathrm{CH} 4 / 2.0 \odot / \mathrm{CO} / 1.50 / \mathrm{CO} 2 / 2.0 \odot / \mathrm{C} 2 \mathrm{H} 6 / 3.0 \odot / \mathrm{AR} / \mathrm{.0} / \mathrm{H}$

$\mathrm{O}+\mathrm{C} 3 \mathrm{H} 7<=>\mathrm{C} 2 \mathrm{H} 5+\mathrm{CH} 2 \mathrm{O}$

$9.640 \mathrm{E}+13 \quad .000 \quad .00$

$\mathrm{H}+\mathrm{C} 3 \mathrm{H} 7(+\mathrm{M})<=>\mathrm{C} 3 \mathrm{H} 8(+\mathrm{M})$

3. $613 \mathrm{E}+13 \quad .000 \quad .00$

LOW/ 4.420E+61 $-13.545 \quad 11357.0 /$

TROE/ . $315 \quad 369.0 \quad 3285.0 \quad 6667.0$ /

$\mathrm{H} 2 / 2.0 \odot / \mathrm{H} 2 \mathrm{O} / 6.0 \odot / \mathrm{CH} 4 / 2.00 / \mathrm{CO} / 1.50 / \mathrm{CO} 2 / 2.0 \odot / \mathrm{C} 2 \mathrm{H} 6 / 3.00 / \mathrm{AR} / \mathrm{.70} /$

$\mathrm{H}+\mathrm{C} 3 \mathrm{H} 7<=>\mathrm{CH} 3+\mathrm{C} 2 \mathrm{H} 5$

$4.060 \mathrm{E}+06 \quad 2.190 \quad 890.00$

$\mathrm{OH}+\mathrm{C} 3 \mathrm{H} 7<=>\mathrm{C} 2 \mathrm{H} 5+\mathrm{CH} 2 \mathrm{OH}$

$2.410 \mathrm{E}+13 \quad .000 \quad .00$

$\mathrm{HO} 2+\mathrm{C} 3 \mathrm{H} 7<=>02+\mathrm{C} 3 \mathrm{H} 8$

$2.550 \mathrm{E}+10 \quad 0.255 \quad-943.00$

$\mathrm{HO} 2+\mathrm{C} 3 \mathrm{H} 7=>\mathrm{OH}+\mathrm{C} 2 \mathrm{H} 5+\mathrm{CH} 2 \mathrm{O}$

$\mathrm{CH} 3+\mathrm{C} 3 \mathrm{H} 7<=>2 \mathrm{C} 2 \mathrm{H} 5$

2. $410 \mathrm{E}+13$

.000

$1.927 \mathrm{E}+13-0.320$

.00

END 